\title{
AVALIAÇÃO DA ADAPTAÇÃO VERTICAL ENTRE INTERMEDIÁRIOS DO TIPO ESTETICONE E CILINDROS METÁLICOS PRÉ-USINADOS, VARIANDO AS CONDIÇÕES: SOBREFUNDIÇÃO, TORQUES E PARAFUSOS DE FIXAÇÃO
}

Dissertação apresentada à Faculdade de Odontologia de Bauru, da Universidade de São Paulo, como parte dos requisitos para obtenção do título de Mestre em Odontologia, Área de Reabilitação Oral.

(Edição Revisada) 


\section{AVALIAÇÃO DA ADAPTAÇÃO VERTICAL ENTRE INTERMEDIÁRIOS DO TIPO ESTETICONE E CILINDROS METÁLICOS PRÉ- USINADOS, VARIANDO AS CONDIÇÕES: SOBREFUNDIÇÃO, TORQUES E PARAFUSOS DE FIXAÇÃO}

\section{LUCIANA MARTINS CRÊS MORAES}

Dissertação apresentada à Faculdade de Odontologia de Bauru, da Universidade de São Paulo, como parte dos requisitos para obtenção do título de Mestre em Odontologia, Área de Reabilitação Oral.

(Edição Revisada)

Orientador: Prof. Dr. Wellington Cardoso Bonachela 


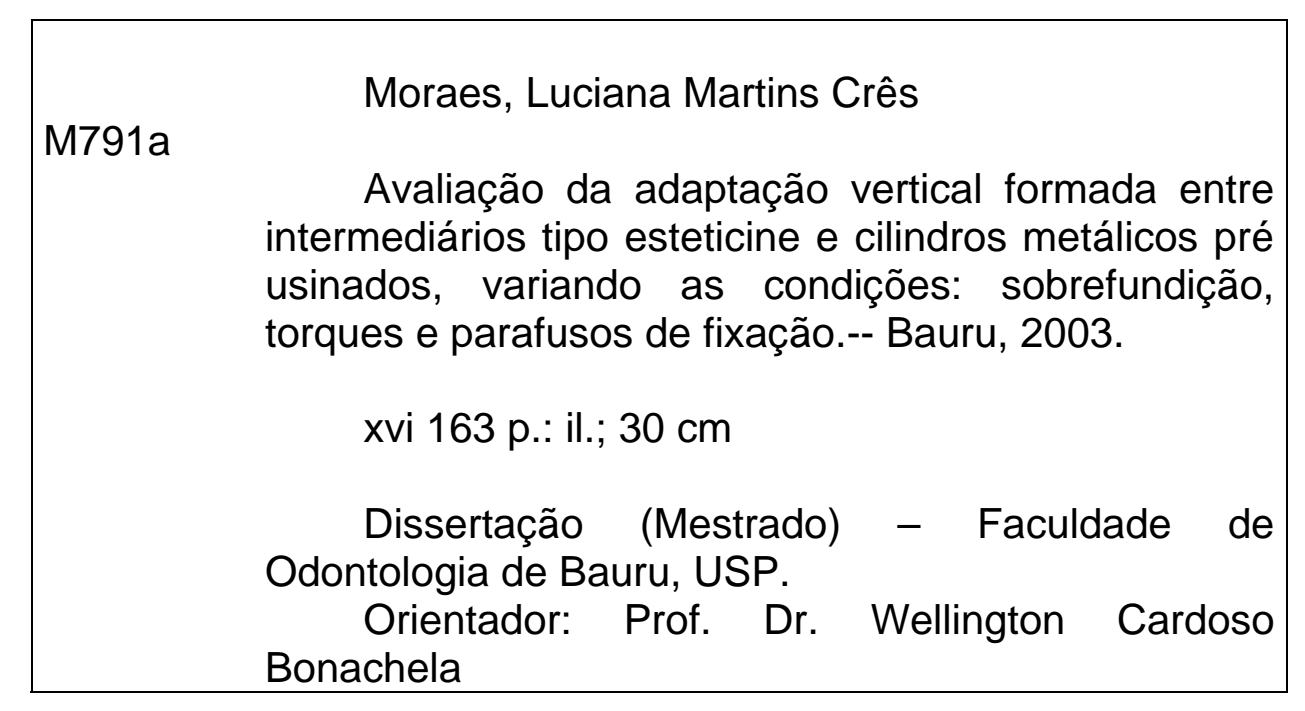

Autorizo, exclusivamente para fins acadêmicos e científicos, a reprodução total ou parcial desta dissertação por processos fotocopiadores e/ou meios eletrônicos:

Data:

Assinatura do autor: 


\section{LUCIANA MARTINS CRÊS MORAES}

Nascimento

15 de abril de 1972

Andradina-SP

Filiação

José Crês

Shirley Martins Crês

1990-1993

Curso de Odontologia:

Universidade de Marília- Unimar

1994

Curso de Aperfeiçoamento em Endodontia:

APCD - Associação Paulista de Cirurgiões Dentistas de Bauru- SP

1994-1995

Residência Odontológica na área de Prótese :

HPRLL - em convênio com a Faculdade de Odontologia de Bauru - USP

1996-1997

Curso de Especialização em Implantodontia Osseointegrada:

HPRLL - em convênio com a Faculdade de Odontologia de Bauru - USP

2001-2003

Curso de Mestrado em Odontologia na Área de Reabilitação Oral:

Faculdade de Odontologia de Bauru - USP 
DEDICO ESTE TRABALHO,

A DEUS, que nos deu o Dom da vida, em quem deposito toda a minha fé e gratidão, por dar-me luz e força para a realização deste curso de mestrado.

Aos meus pais, José E SHIRLEY a quem devo a escolha da minha profissão. O orgulho que tenho por ser filha de vocês é tão grande quanto a admiração que tenho por vocês. Muito obrigada por vocês existirem !

Ao meu esposo EDGARD, por todo o seu incentivo e apoio nesta caminhada. Se hoje estou aqui, é a você devo essa conquista, que na verdade é nossa. Meu AMOR muito abrigada. Te amo!

A minha querida irmã FABIANA companheira e melhor amiga, em quem sempre encontro apoio e carinho. Aprendemos, desde criança, a compartilhar todos os momentos e esse é mais um momento especial. Dedico também a ela essa conquista.

A toda Minha FAMílı que sempre me dispensaram um grande carinho e dedicação. 


\section{AGRADECIMENTO ESPECIAL}

Ao meu orientador Prof. Dr. Wellington Cardoso Bonachela, serei sempre grata pela orientação, pelos ensinamentos e pela confiança que em mim depositou. Obrigada, sobretudo, pela paciência e atenção a mim dispensadas. 


\section{AgRADECIMENTOS}

À Direção da Faculdade de Odontologia de Bauru, Universidade de São Paulo, na pessoa da Diretora Prof. Dra. Maria Fidela de Lima Navarro.

A Comissão de Pós-Graduação da Faculdade de Odontologia de Bauru, Universidade de São Paulo, na pessoa do Presidente Prof. Dr. José Carlos Pereira.

Aos Professores do Departamento de Prótese: Prof. Dr. Gerson Bonfante, Prof. Dr. Paulo Martins Ferreira, Prof. Dr. Milton Carlos Gonçalves Salvador, Prof. Dr. José Henrique Rubo, Prof. Dr. Carlos dos Reis Pereira Araujo, Prof. Dr. Paulo Rodrigues Conti, Prof. Dr. Vinícius Carvalho Porto, Prof. Dr. Renato de Freitas, Profa. Dra. Lucimar Falavinha Vieira, pela orientação e pelos valiosos ensinamentos que muito contribuíram para o meu crescimento profissional.

Ao Prof. Dr. Luiz Fernando Pegoraro, pelos conhecimentos transmitidos na clínica de reabilitação oral.

Ao Prof. Dr. Accácio ins do Valle, pela amizade, consideração, ajuda e incentivo. 
Ao Prof. Dr. Milton Carlos Gonçalves Salvador, Prof. Dra. Lucimar Falavinha Vieira e Prof. Dr. Vinícius Caravalho Porto, pelos ensinamentos e orientações na disciplina de prótese total.

Aos amigos de mestrado: Jefferson, Rafael, Luiz Gustavo, Renato, Osvaldo, Mauro, Tatiany e Mariana, pelo carinho e ajuda que sempre recebi de todos vocês. Foi extremamente enriquecedor conhecer e conviver com cada um de vocês.

A minha grande amiga Stella, que durante todo o mestrado me ajudou com muito carinho. Você fez esta caminhada realmente se tornar mais fácil. Agradeço por tudo de coração.

Aos meus amigos Paulo e Leylha, que me ajudaram com muito carinho, na parte estatística e formatação desse trabalho. Muito obrigado.

Aos colegas do doutorado: Rudys, Carlinhos, Barnabé, Juliano, Anuar, Stefânia, Nelsinho, Vinícios e Gildo, agradeço pela convivência harmoniosa e atenção com que sempre me trataram.

Aos colegas do estágio e atualmente fazem parte do curso de mestrado: Tânia, Mikaela, Jonas, Stevan, Samara, Sadan e Érico. 
A D. Ana , D. Cleusa e Eduardo pelo carinho e dedicação com que sempre me receberam na clínica da Pós-Graduação.

Ao Reivanildo, Marcelo e Valquíria, pela atenção e colaboração, sempre que precisei.

Às secretárias do Departamento de Prótese, Edna, Débora e Claudia, que sempre me ajudaram e me receberam com grande amizade e consideração.

Ao funcionário da Disciplina de Endodontia, Edmauro, pela disponibilidade dispensada no microscópio de varredura.

A todos os funcionários do Serviço de Biblioteca e Documentação, pela colaboração e disponibilidade constantes.

Aos funcionários da Secretaria de Pós-Graduação, que sempre demonstraram disponibilidade e atenção.

A empresa Conexão Sistema de Prótese, em nome do Dr. Rodolfo Candia Alba Jr. pela cessão de uma parte do material utilizado neste trabalho. 
À CAPES pela concessão da bolsa de estudo para realização deste curso.

Ao Laboratório de Prótese onde foram realizados a parte experimental deste trabalho, em especial ao Sidnei.

Aos alunos e pacientes, te tive contato, meu afeto e minha sincera gratidão.

Gostaria de agradecer a cada pessoa que, por um motivo ou outro, contribuíram para realização deste trabalho, e que porventura eu não lembrei de citar. 


\section{SUMÁRIO}

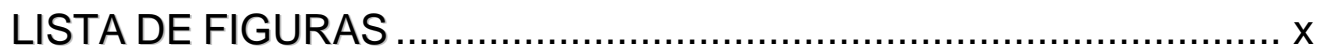

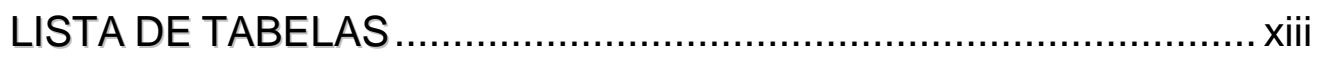

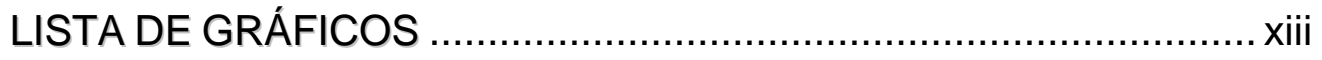

LISTA DE ABREVIATURAS E SÍMBOLOS ............................... xiii

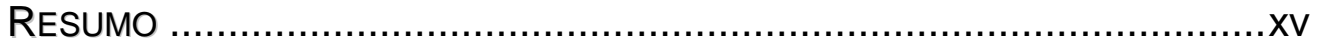

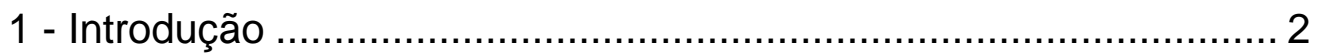

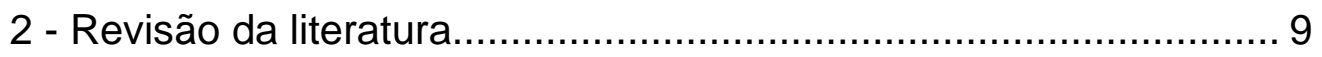

3- Proposição ........................................................... 100

4- Material e Métodos ........................................................... 102

5- Resultados ................................................................... 121

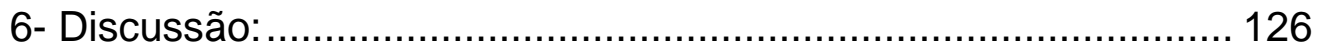

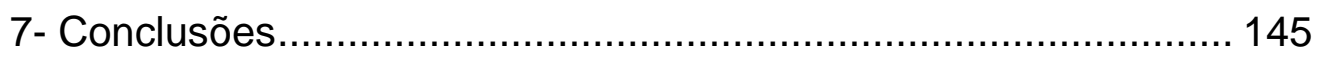

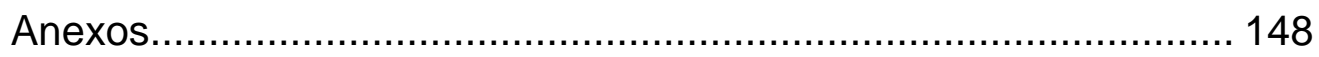

REFERÊNCIAS BIBLIOGRÁFICAS .................................... 151

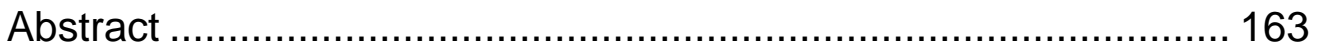




\section{LISTA DE FIGURAS}

FIGURA 4.1.1: BASE SEXTAVADA, IMPLANTE E INTERMEDIÁRIO. 103

FIgURA 4.1.2: BASE SEXTAVADA, IMPLANTE INSTALADO NO ORIFÍCIO CENTRAL E INTERMEDIÁRIO. 103

FIGURA 4.1.3: INSTALAÇÃO DO INTERMEDIÁRIO À BASE ATRAVÉS DO Controlador DE TORQUe (NoBEl BIOCARE). 104

FIgURA 4.2.1- A: PARAFUSO DE FIXAÇÃO DA PRÓTESE EM TITÂNIO, B: PARAFUSODE FIXAÇÃO DA PRÓTESE EM OURO, C: CILINDRO DE OURO E D- VISÃO OCLUSAL DO HEXÁGONO DO FIXAÇÃO. 105

Figura 4.3.1: MicroscóPIO ÓPtico Mitutoyo, MODELO 5050/JAPAN........ 107

FIgURA 4.3.2: CONTROLAdOR DE TORQUE (NobEL BIOCARE)....................... 107

FIGURA 4.3.3: EXEMPLO DA INSTALAÇÃO DE UM CILINDRO AO INTERMEDIÁRIO ATRAVÉS DO TORQUÍMETRO (MORSA ADAPTADA À MESA PARA FIXAR O CORPO DE PROVA) 108

FIGURA 4.3.4: LEITURA DA ADAPTAÇÃO VERTICAL DE UM CILINDRO EM MICROSCÓPIO ÓPTICO. 108

FIgURA 4.3.5: BASE SEXTAVAdA NUMERADA COM O CILINDRO EM POSIÇÃO, TAMBÉM MARCADO 109 
FIgURA 4.3.6: CORTE ESQUEMÁtICO E SEQÜÊNCIA NUMÉRICA DAS ÁREAS ONDE ERAM FEITAS AS MEDIÇÕES ENTRE INTERMEDIÁRIOS E CILINDROS. ..... 110

Figura 4.4.1- A : Conjunto esteticone/implante transferidos para, B: Base utilizada na fase laboratorial. 112

FIGURA 4.4.2- A: CILINDRO EM POSIÇÃO, B: ENCERAMENTO PARA A CONFECÇÃO DA MATRIZ.

Figura 4.4.3- MATRIZ CONFECCIONAdA. A: MATRIZ EM POSIÇÃo NA BASE CILÍNDRICA E B: VISÃO OCLUSAL DA MATRIZ EM SILICONE E BASE. 113

FIgURA 4.4.4- SEQÜÊNCIA DA REALIZAÇÃO DOS ENCERAMNETOS DE TODOS OS CORPOS DE PROVA. 113

Figura 4.4.5- LigAS UTILIZAdAs (VERA BONd II E PROTON). 114

FigURA 4.5.1- A: SPRUE HORIZONTAL E B- BASE FORMAdORA DE CADINHO.......114

FiguRA 4.5.2- A: CORPOS DE PROVA ENCERADOS, B: VISTA LATERAL DOS CORPOS DE PROVA ENCERADOS E C: POSICIONAMENTO DOS CORPOS DE PROVA NO ANEL ANTES DA INCLUSÃO 115

FiguRA 4.5.3- ANEL DE SiLICONE SOBRE A BASE FORMAdORA DE CADINHO, COM OS CORPOS DE PROVA POSICIONADOS. 116

FIGURA 4.6.1- CORPOS DE PROVA APÓS A SOBREFUNDIÇÃO, JATEADOS E LIMPOS ANTES DE SEREM SEPARADOS DO SPRUE E CANAIS DE ALIMENTAÇÃO. 118

FIGURA6.1- FOTOMICROGRAFIA DA INTERFACE CILINDRO/INTERMEDIÁRIO DO GRUPO I MOSTRANDO ALTERAÇÃO DA ADAPTAÇÃO VERTICAL E IRREGULARIDADES NOS BORDOS. 
FIGURA 6.2- FOTOMICROGRAFIA DA INTERFACE CILINDRO/INTERMEDIÁRIO DO GRUPO II, MOSTRANDO ALTERAÇÃO DA ADAPTAÇÃO VERTICAL E IRREGULARIDADES NOS BORDOS.

FIGURA 6.3- EXEMPLO DE CILINDRO DE OURO ( GRUPO I) COM MAIOR ADAPTAÇÃO VERTICAL. 132

FIGURA6.4- EXEMPLO DE CILINDRO DE OURO (GRUPO I) COM MAIOR DESADAPTAÇÃO VERTICAL 132

FIGURA 6.5- EXEMPLO DO CILINDRO DE NICR (GRUPO II) COM MAIOR ADAPTAÇÃO VERTICAL. 133

FIgURA6.6- EXEMPLO DO CILINDRO DE NICR (GRUPO II) COM MAIOR DESADAPTAÇÃO VERTICAL. 133 


\section{LISTA DE TABELAS}

TABELA 1- MÉdIA E DESVIO-PADRÃO DA ADAPTAÇÃO VERTICAL DAS AMOSTRAS DE NICR E OURO, COM PARAFUSO DE OURO E TORQUES DE 10 E 20NCM, ANTES E APÓS AS SOBREFUNDIÇÕES. 121

TABELA 2- MÉdIA E DESVIO-PADRÃO DA ADAPTAÇÃO VERTICAL DAS AMOSTRAS DOS CILINDROS DE NICR E OURO, COM PARAFUSO DE TITÂNIO E TORQUES DE 10 E 20NCM, ANTES E APÓS AS SOBREFUNDIÇÕES. 122

TABELA 3- ComparaçÃo ENTRE os VALORES dA ADAPTAÇÃO VERTICAL, ANTES E APÓS AS SOBREFUNDIÇÕES, COM UTILIZAÇÃO DO PARAFUSO DE OURO. 123

TABELA 4- CoMPARAÇÃo ENTRE OS VALORES DA ADAPTAÇÃO VERTICAL, ANTES E APÓS AS SOBREFUNDIÇÕES, COM UTILIZAÇÃO DO PARAFUSO DE TITÂNIO. .... 123

TABELA 5- DIFERENÇAS ENTRE AS MÉDIAS DA ADAPTAÇÃO VERTICAL, ANTES E APÓS AS SOBREFUNDIÇÕES, COM VARIAÇÃO DO MATERIAL DO PARAFUSO, QUANTIDADE DE TORQUE E TIPO DE LIGA UTILIZADA, EM MICROMETROS. ...... 124 
GRÁFICO 5.1- REPRESENTAÇÃO GRÁFICA DAS MÉDIAS E DESVIO PADRÃO DA ADAPTAÇÃO VERTICAL, DOS CILINDROS DE OURO E NICR ANTES E APÓS A SOBREFUNDIÇÃO E TROQUE DE 10 E 20 NCM. 122

GRÁFICO 5.2- REPRESENTAÇÃO GRÁFICA DAS MÉDIAS E DESVIO PADRÃO DA ADAPTAÇÃO VERTICAL, ANTES E APÓS A SOBREFUNDIÇÃO, COM VARIAÇÃO DA LIGA DOS PARAFUSOS DE FIXAÇÃO, QUANTIDADE DE TORQUE E CILINDRO UTILIZADO. 124

Gráfico 6.1- Representação gráfica das médias da adaptação vertical expressas em micrometros dos grupos I e II, ao torque de 10 e $20 \mathrm{Ncm}$, antes da sobrefundiçao. 130

GRÁFICO6.2- REPRESENTAÇÃO GRÁFICA DAS MÉdIAS DA ADAPTAÇÃO VERTICAL EXPRESSAS EM MICROMETROS DO GRUPOS I E II, AO TORQUE DE 10 E 20 NCM , APÓS A SOBREFUNDIÇÃO. 140 


\section{LISTA DE ABREVIATURAS E SÍMBOLOS}

$\%$

${ }^{\circ} \mathrm{C}$

$\mu \mathrm{m}$

ADA

$\mathrm{AgPd}$

CAD

$\mathrm{CoCr}$

$\mathrm{cm}$

g

$\mathrm{He}$

$\mathrm{Hi}$

$\mathrm{Hz}$

$\mathrm{K}$

$\mathrm{Kg}$

MEV

$\mathrm{Ml}$

$\mathrm{Mm}$

$\mathrm{MPa}$

$\mathrm{N}$

$\mathrm{Ncm}$

$\mathrm{NiCr}$

PPF

RMF

PTV

$\mathrm{Ti}$

UCLA
Porcentagem

Grau Celcius

Micrometros

American Dental Association

Paládio-prata

Computer Assisted Designed

Cobalto-cromo

Centímetro

Gramas

Hexágono externo

Hexágono interno

Hertz

Grau Kelvin

Quilogramas

Microscópio eletrônico de varredura

Mililitros

Milímetros

Mega Pascal

Newtons

Newtons por centímetros

Níquel-cromo

Prótese parcial fixa

Restauração metálica fundida

Perioteste

Titânio

University of California - Los Angeles 
RESUMO

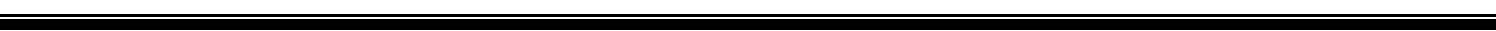




\section{RESUMO}

A adaptação de próteses sobre implantes é considerada um fator primordial para o sucesso destas longitudinalmente. Este estudo observou a adaptação vertical entre intermediário tipo esteticone e cilindros pré-fabricados antirotacionais para próteses unitárias em diferentes ligas. Foram selecionados cilindros de ouro da empresa Conexão (Conexão Sistemas de Prótese - São Paulo- SP- Brasil) e cilindros de níquel/cromo pré-fabricados em um laboratório comercial. A mensuração da adaptação vertical foi realizada em microscópio óptico, antes da sobrefundição, ao torque de $10 \mathrm{Ncm}$ e $20 \mathrm{Ncm}$ variando-se os parafusos de fixação. Encontraram-se medidas que variaram de 14,02 \pm 5,63 $\mu \mathrm{m}$ para os cilindros de níquel/cromo, antes da sobrefundição ao torque de $10 \mathrm{Ncm}$, e $10,95 \pm 5.68 \mu \mathrm{m}$ para o torque de $20 \mathrm{Ncm}$. E para os cilindros de ouro, ao torque de $10 \mathrm{Ncm}$, a média encontrada foi de $14,41 \pm 3,84 \mu \mathrm{m}$ e ao torque de $20 \mathrm{Ncm}$ foi de 12,26 $\pm 3.69 \mu \mathrm{m}$. Após as leituras iniciais, os cilindros receberam enceramento, foram incluídos e fundidos com ligas de paládio/prata para o cilindro de ouro, e níquel/cromo para o cilindro de níquel/cromo e novamente analisados. As medidas variaram de $20,93 \pm 7,10 \mu \mathrm{m}$ a $10 \mathrm{Ncm}$ e $15,77 \pm 4,72 \mu \mathrm{m}$ a $20 \mathrm{Ncm}$ para os cilindos de níquel/cromo fundidos em níquel /cromo, e de 11,79 \pm 4,06 $\mu \mathrm{m}$ ao torque de $10 \mathrm{Ncm}$ e $9,59 \pm 3,25 \mu \mathrm{m}$ à $20 \mathrm{Ncm}$ para os cilindros de ouro sobrefundidos em paládio/prata. Os resultados obtidos demonstraram que o cilindros de ouro com maior torque apresentaram-se mais adaptados antes e 
após a sobrefundição. Foram encontradas diferenças estatisticamentes significantes também quando a liga de paládio/prata foi empregada. Concluiu-se então que as próteses unitárias sobre implantes são indicadas sendo que ligas nobres e seminobres apresentam menores variações estruturais. 
INTRODUÇÃO 


\section{1 - Introdução}

Com a descoberta da osseointegração pelo professor Bränemark, na década de $50^{17}$ os estudos sobre a implantodontia se intensificaram e hoje possibilitam confecções de reabilitações protéticas em indivíduos com limitações anatômicas e funcionais proporcionando, de uma maneira organizada e confiável, o restabelecimento da estética, função e fonética. Com esse grande advento, o uso de implantes dentários para substituir dentes ausentes tem-se tornado uma prática rotineira e importante na Odontologia moderna, permitindo que as mais variadas combinações protéticas sejam agora realizadas, apresentando-se mais estáveis, retentivas e estéticas. Apresentando, também, outros aspectos positivos como evitar desgastes de dentes íntegros, supostos pilares para próteses fixas; imposições de cargas laterais aos dentes pilares de próteses parciais removíveis com extremo livre e entre outras inúmeras situações. Contando atualmente com esses recursos, essas reabilitações na cavidade oral irão restabelecer a saúde do paciente como um todo, possibilitando devolver dentes para pacientes desdentados totais e/ou parciais com um significativo ganho estético para aqueles que o almejam, melhorando assim significativamente a qualidade de vida e convívio social desses pacientes.

As primeiras aplicações clínicas das próteses sobre implantes osseointegrados foram reabilitações totais de mandíbulas e maxilas. Com o caráter evolutivo dos trabalhos, foi possível também restaurar espaços protéticos parciais com próteses fixas menos extensas e, finalmente, a de um único elemento dentário perdido. 
Sendo assim, as resoluções protéticas unitárias sobre os implantes foram as últimas a serem desenvolvidas pela maioria dos sistemas de implantes. Isso ocorreu devido ao fato das necessidades de reposições protéticas unitárias constituírem o grande desafio para a Odontologia Restauradora, principalmente quando a estética estiver envolvida, porque além dos requisitos técnicos e biomecânicos, essas restaurações devem acompanhar as referências dos dentes naturais vizinhos, tais como: forma, contorno, textura superficial do esmalte, etc. Os primeiros componentes das próteses sobre os implantes deixavam muito a desejar, pois as coroas eram construídas com sobrecontorno vestibular semelhante a pônticos de próteses fixas convencionais, não ideais, não atingindo assim a estética e a condição biomecânica proposta. Na atualidade, os implantes devem ser posicionados de tal forma que permitam um perfil de emergência adequado da futura coroa, onde o componente protético deve emergir de dentro do sulco periimplantar. Para isso a localização ideal dessa fixação, contorno gengival, disponibilidade óssea e a escolha de componentes protéticos corretos são alguns itens que devem ser considerados nos planejamentos atuais.

As principais vantagens do uso das próteses unitárias sobre implantes em relação às fixas convencionais são: não sacrificar tecidos dentários sadios dos dentes adjacentes ao espaço protético, a individualização de dentes não sendo necessária a união de três dentes como em próteses fixas convencionais e os reparos eventuais ou substituição dessas próteses que assumem um aspecto mais simples que as convencionais. Hoje essas próteses unitárias podem assumir uma grande variabilidade de estilo tais como conexão direta aos implantes osseointegrados ou apresentar elementos intermediários (abutment) entre o implante e a coroa protética, podendo, ainda, essas próteses ser cimentadas a 
esses intermediários ou retidas por parafusamento. As próteses retidas por parafusos apresentam além, das vantagens inerentes às suas adequações aos implantes, uma característica peculiar que é a sua reversibilidade, podendo ser recuperada ou reavaliada periodicamente por meio da soltura dos parafusos que a conectam ao corpo do implante e/ou ao intermediário ${ }^{80}$, possibilitando a interceptação de algum possível dano que possa acontecer à base do assentamento dos implantes, decorrentes das cargas mastigatórias, tornando-se assim mais previsíveis.

Além de suas vantagens inerentes, para o completo sucesso dessas próteses um outro fator deverá ser levado em consideração que é o tipo de cilindro protético, o qual deverá ser acoplado sobre os intermediários, no que diz respeito às suas características individuais, sem gerar desadaptações, já que atualmente podemos também contar com diferentes tipos de ligas e técnicas de fundições, as quais vêm viabilizando uma grande versatilidade na escolha desses elementos.

Existem em torno de 550 tipos diferentes de ligas descritas para uso odontológico no mercado americano ${ }^{78}$. A escolha da liga a ser utilizada em Odontologia está ligada a uma série de fatores e, dentre eles, podem-se citar a disponibilidade de matérias-primas, a viabilidade técnica e econômica do processo de fabricação e a possibilidade de obtenção de propriedades favoráveis. Então, a liga ideal para confecção de próteses metalo-cerâmicas deve conter certos requisitos, tais como: ser bem tolerada pelos tecidos bucais, resistente ao descoloramento e à corrosão, não ser tóxica, promover boa adesão com a porcelana produzindo, assim, uma nítida junção entre o metal e a porcelana, ter uma expansão compatível à do material cerâmico, apresentar boas características 
de fundição, permitir peças adequadamente ajustadas e boa soldagem. Finalmente, ela deve possuir um alto módulo de elasticidade, coeficiente de escoamento e dureza adequados e possibilitar um bom acabamento ${ }^{83}$.

As ligas à base de ouro foram as primeiras a serem empregadas na Odontologia, iniciando-se as pesquisas por LANE em 1908. Atualmente são, também, as mais indicadas para próteses sobre implantes devido a sua boa adaptação. Porém, além do custo muito elevado, determinadas condições não permitem a essas ligas o recobrimento cerâmico, atualmente utilizado praticamente na maioria das reconstruções protéticas devido às características adequadas de reprodutibilidade e semelhança aos dentes humanos. Assim sendo, os profissionais passam a utilizar ligas não nobres em seus trabalhos.

Como as condições de realização das próteses de hoje se assemelham às mesmas deparadas pele classe odontológica num passado recente, as discussões de hoje se adequam às condições iniciais.

Por volta de 1968, com o propósito de diminuir os custos e favorecer as diferentes condições sociais da população, começou-se a estudar e pesquisar outras ligas não preciosas para fabricação de próteses metalo-cerâmica, sendo elas à base de cobalto-crômio ou cobalto-níquel-crômio. Um dos pioneiros no estudo dessas ligas foram POGGIOLI et al., em 1968, quando observaram que o níquel, sendo parte da liga, era o elemento que formava uma forte união com o opaco de várias porcelanas. Aliado aos testes laboratoriais, o uso da liga de $\mathrm{NiCr}$ foi cada vez mais acentuado nos trabalhos clínicos, proporcionando mais confiança na sua indicação devido as suas características tais como: módulo de elasticidade superior, densidade menor, resistência nove vezes maior e menor flexibilidade. 
Porém, como o meio cientifico sempre está à procura de inovações e melhorias, atualmente são grandes as expectativas com as ligas de titânio em relação às restaurações protéticas devido as suas propriedades inerentes: 1- alta resistência mecânica, 2- alta resistência à corrosão, 3- biocompatibilidade, 4ação bacteriostática contra a flora bacteriana encontrada na cavidade bucal e 5único metal que pode ser soldado na boca. Além dessas características apresenta a vantagem de ter um menor custo em relação às ligas áureas.

As fundições de próteses sobre implantes na atualidade, ainda apresentam um certo grau de não-previsibilidade, sendo que, dentro de certos parâmetros, esses aspectos podem ser clinicamente aceitos; porém, as preocupações mecânicas se manifestariam de forma a dificultar a obtenção de adaptação passiva entre as infra-estruturas metálicas obtidas, intermediários e seus componentes, quando os parafusos de fixação de ouro e/ou titânio são apertados.

Uma técnica mundialmente aceita, a qual determina uma excelente precisão, é a que utiliza cilindros de ouro pré-fabricados usinados e fundidos em ouro tipo IV, para recobrimento de material estético resina ou cerômero, ou ligas de ouro de alta fusão adequadas a revestimentos estéticos cerâmicos. Apesar de possibilitar boas propriedades biológicas, físicas e de adaptação, essas ligas ainda apresentam o problema de um alto custo, não se enquadrando às condições econômicas de grande parte da população que necessita de tratamentos protéticos reabilitadores.

Trabalhos que comparam as interfaces verticais estabelecidas entre intermediários e próteses fundidas com diferentes ligas metálicas apresentam metodologias diferentes e, por conseguinte, valores estatisticamente diferentes entre si, variando de liga para liga e também em função do torque dado aos 
parafusos de fixação nessas próteses. Um outro aspecto a ser abordado seria a condição de estabelecimento de uma conduta ou parâmetro adequados a próteses que se destinassem a substituir apenas um elemento, ou quando necessitam substituir mais de um elemento unido por soldagem, determinando a condição de uma PPF.

Reconhecendo as necessidades presentes que toda a população enfrenta: como a redução dos custos operacionais para a realização das reabilitações orais sobre implantes, e os profissionais vendo-se cada vez mais seduzidos pelo surgimento de novos materiais, buscou-se realizar uma avaliação da adaptação vertical de cilindros protéticos para esteticone torneados pré-fabricados e sobrefundidos em liga de $\mathrm{NiCr}$ e $\mathrm{AgPd}$, variando-se a condição de torque dado a dois tipos de parafusos de fixações (ouro e titânio). 
REVISÃO DA LITERATURA 


\section{2 - Revisão da literatura}

\section{1- Condições protéticas em peças unitárias.}

Em um dos primeiros relatos sobre a biomecânica das próteses sobre implantes foi realizado em 1983. SKALAK ${ }^{100}$ comentou que o aspecto crítico do sucesso ou falha dos implantes é a maneira como os estresses mecânicos são transferidos dos implantes ao tecido ósseo. É essencial que tanto o tecido ósseo como os implantes sejam submetidos somente a forças as quais estão aptos a receber. Uma conexão rígida da prótese parcial fixa com o implante osseointegrado resulta em uma estrutura única, na qual o implante, a prótese e o tecido ósseo agem como uma unidade. Qualquer desalinhamento que haja da prótese com os implantes, resultará em um estresse interno nesta, no implante e também no osso. Enfatizou ainda que muito embora essas condições de estresses não possam ser detectados por análise visuais, podem ocasionar falhas em todo o sistema.

JEMT; LEKHOLM; GRONDAHL ${ }^{52}$, em 1990, um estudo de acompanhamento clínico, avaliaram reconstruções protéticas unitárias suportadas por implantes do tipo Bränemark durante um período de três anos. Neste um grupo de 16 pacientes (oito homens e oito mulheres), receberam 21 implantes na maxila e dois implantes na mandíbula, totalizando 23 fixações. Exames clínicos foram realizados inicialmente, duas semanas, e três meses após a instalação das coroas e como nenhum problema mecânico ou patológico foi encontrado, os pacientes foram orientados para controle anual. Após três anos em função, os 
implantes/coroas foram reexaminados quanto à estabilidade, presença ou ausência de placa, recessão gengival, nível ósseo e estabilidade das coroas. Após 30 meses de função, dois implantes foram perdidos, sendo que 21 implantes (91\%), permaneceram estáveis durante o período de observação. As complicações protéticas incluíram a substituição de 13 restaurações de uma só vez, e duas restaurações tiveram que ser substituídas duas vezes, durante os três anos de seguimento; nove destas substituições foram devido a razões estéticas e cinco por razões mecânicas união dos parafusos. Outras três restaurações foram trocadas por trauma ou fraturas do material de revestimento. Dez restaurações (43\%) permaneceram estáveis no primeiro ano de função e oito (35\%) durante todo o período de avaliação, sendo que a condição de afrouxamento do parafuso foi encontrado em $57 \%$ das restaurações durante o primeiro ano. Fístulas foram associadas a afrouxamento de quatro restaurações e tratadas com reaperto dos parafusos do pilar.

No ano seguinte JEMT et al. ${ }^{51}$, relataram os resultados de outro estudo de acompanhamento clínico onde foram colocados 107 implantes unitários em 92 pacientes (45 homens e 47 mulheres), em sete centros clínicos internacionais. $82 \%$ dos implantes foram colocados na maxila e $18 \%$ na mandíbula. A avaliação clínica foi realizada através de controles de uma semana, 6, 12, 24, 36, 48 e 60, após a inserção da coroa; nesta parte do estudo o controle foi realizado até 12 meses. Os seguintes parâmetros clínicos foram registrados: gengivite, profundidade de sondagem, índice de sangramento, e mobilidade dentária. Neste período somente três implantes $(2,8 \%)$ foram perdidos. A condição gengival se apresentou saudável (82\% dos pacientes) em volta das coroas, coincidindo com a situação clínica dos dentes naturais adjacentes. Fístulas foram encontradas em 
11 restaurações (10\%); em seis destas foram associadas à mobilidade dos parafusos do pilar. A principal complicação associada a restaurações ou componentes protéticos foi o afrouxamento dos parafusos do pilar (26\%), em 21 restaurações (20\%) ocorreu afrouxamento uma vez, e em oito restaurações (7,5\%) ocorreu afrouxamento dos parafusos varias vezes, A freqüência de afrouxamento dos parafusos teve uma tendência a diminuir com a progressão do estudo.

No ano de 1991, LAZZARA $^{67}$ publicou um trabalho enumerando as vantagens dos implantes com hexágono externo, que segundo ele, inicialmente este hexágono foi desenhado para levar o implante ao leito cirúrgico. As principais vantagens deste tipo de conexão são obtidas na fase protética, onde uma conexão mais estável entre o implante e a restauração é necessária. O mecanismo anti-rotacional desta conexão é importante para estabilizar a correta angulação dos pilares, isto é fundamental em restaurações unitárias. Uma das vantagens do hexágono coronal é que sua posição pode ser transferida para o modelo de trabalho através de componentes de moldagens, que transferem a localização do implante; permitindo ao técnico reproduzir a correta posição deste; isto permite selecionar componentes para próteses unitárias, idealizando a angulação do implante e dos componentes, assim como o perfil de emergência, o que permite a construção de restaurações estéticas e funcionais. O pilar tipo UCLA também comentado pelo autor neste trabalho, adapta-se à conexão hexagonal do implante, permitindo a construção de restaurações unitárias onde existam $4 \mathrm{~mm}$ ou menos de altura do dente antagonista à parte superior do implante; podendo ser encontrado em plástico ou pré-fabricado em ouro, este último é recomendado por ser mais exato e preciso, diminuindo os erros 
laboratoriais no encaixe ao implante. Este tipo de pilar também permite a construção de restaurações onde é eliminada a possibilidade de emergência do parafuso de retenção através da face vestibular. Segundo o autor, assentamento positivo do parafuso de retenção e um encaixe preciso dos hexágonos são críticos para a estabilidade ao longo do tempo da restauração, já que a restauração unitária é estabilizada através do hexágono coronal do implante.

Existe uma grande dificuldade para obter uma infra-estrutura bem adaptada, porque todo passo para a confecção de uma prótese implanto suportada é crítico. Pensando nisso GOLL ${ }^{38}$, em 1991, sugeriu algumas soluções para melhorar a precisão das próteses, reduzindo desta forma alguns erros:

Usar componentes usinados, pois sua adaptação é mais previsível;

Checar a adaptação do cilindro de ouro e componentes de transferência nos intermediários na primeira consulta, para assegurar que todos os componentes se adaptem adequadamente;

1. Cobrir os intermediários com a capa de proteção para impedir que resíduos se acumulem na superfície do mesmo;

2. Verificar a precisão do modelo através de um guia em resina acrílica, o qual deve ser construído um dia antes;

3. Usar pinos de laboratório novos para as fases laboratoriais e para avaliar a adaptação da peça clinicamente. O teste da infra-estrutura é feito com um parafuso no implante mais distal;

4. Limpar a superfície de contato do cilindro de ouro com solvente de cera antes da inclusão;

5. Usar capas de proteção de cilindros de ouro durante o acabamento e polimento da infra-estrutura; 
6. Para fundição de próteses extensas usar cilindros de ouro de $4 \mathrm{~mm}$, então a infra-estrutura será mais volumosa e firme, o mesmo ocorrendo com o guia.

SORENSEN; AVERA; TOMAS $^{99}$; em 1991, estudaram a fidelidade nas interfaces de diferentes sistemas de implantes. Compararam a interface implante/intermediário (I-I) e intermediário/prótese (I-P) de 4 sistemas de implantes: grupo 1- 3i; grupo 2- Collagen-Osseodent; grupo 3- Collagem Ossotite e grupo 4- Nobelpharma. O cilindro de ouro foi avaliado após a confecção da infra-estrutura e aplicação da porcelana. Através de observação direta com auxilio de um microscópio com unidade de medição e aumento de 200x os resultados obtidos foram: grupo1- I-I= 34um, I-P=48um; grupo 2- I-I=68um, I-P=96um; grupo 3- I-I=65um, I-P=119um; e o grupo 4- I-I=98um, I-P=78um; sendo que 0 grupo 1 apresentou uma fidelidade de interface significativamente melhor que os demais. Os autores concluíram que deve haver diferentes níveis de tolerância na confecção de vários componentes de implantes.

Em trabalho publicado em 1992, JEMT; LINDÉN; LEKHOLM ${ }^{53}$, trataram 96 maxilas e mandíbulas edêntulas consecutivamente com 127 PPF suportadas por 354 implantes. Os pacientes foram observados por um período de 1 ano e a taxa total de sucesso foi de $98,6 \%$ dos implantes examinados. Nenhuma das próteses inseridas foram perdidas durante o período de observação. Os problemas mais comuns durante o primeiro ano de função estavam relacionados ao afrouxamento dos parafusos de ouro e reclamações estéticas, complicações facilmente resolvidas. Além disso, o número de complicações foi baixo e menor para as próteses fixas de arco inteiro. 
LEVIS; LLAMAS; AVERA ${ }^{73}$, em 1992, reportaram através de um trabalho de publicação os vários usos do pilar UCLA, suas vantagens e desvantagens quando comparado com componentes convencionais. Apresentaram também os resultados de uma avaliação clínica de quatro anos de uso do pilar UCLA. Uma vantagem deste componente mencionada pelos autores é que a restauração confeccionada emerge desde os tecidos gengivais o que permite uma restauração mais estética. Os autores também comentaram que os processos de fundição são mais sensíveis tecnicamente, enquanto que os componentes pré-fabricados são mais precisos. Dessa forma, uma fundição com uma pobre adaptação, resulta em afrouxamento ou fratura do parafuso, e possibilidade de fratura ou perda do implante, portanto uma adaptação precisa é necessária neste tipo de componente. Também relataram os resultados de um estudo clínico de quatro anos utilizando este pilar sobre implantes Bränemark. Explicaram que problemas envolvendo distância interoclusal limitada, estética, angulação, distância interproximal reduzida, foram resolvidos; sendo que para 46 pacientes tratados com 118 pilares UCLA a porcentagem de sucesso foi de 95,8\%.

Para BINON et al. $^{11}$, em 1993, um encaixe impreciso entre os componentes implante/abutment/coroa poderá influenciar no prognóstico a longo prazo da terapia reabilitadora com implantes. As implicações clínicas decorrentes desse encaixe pobre seriam: perdas freqüentes dos parafusos, fratura crônica do parafuso, alta retenção de placa bacteriana, resposta adversa dos tecidos moles ao redor do implante e finalmente, perda da osseointegração. Por esses motivos os autores conduziram um trabalho in vitro para avaliar a compatibilidade entre componentes de 4 diferentes sistemas de implantes, avaliando especificamente a interface implante/pilar de conexão. Os sistemas testados foram Nobelpharma, 
Swede-Vent, Osseodent e Implant Innovations. Os resultados sugeriram que os componentes dos sistemas Implant Innovations e Swede-Dent podem ser combinados entre si, alcançando um bom nível de compatibilidade. Entretanto, sugerem também que antes do uso, deva-se testar manualmente o encaixe desses componentes, evitando-se surpresas desagradáveis no momento da realização de procedimentos nos pacientes.

Em 1993 foi realizado um estudo por SAKAGUCHI; BORGERSEN ${ }^{93}$, para avaliar a performance biomecânica dos componentes de restaurações para implantes osseintegrados relacionados a infra-estrutura, especificamente a interface entre coroa e o parafuso de ouro de retenção e a interface entre a coroa e o abutment. Isto é de grande interesse devido a prevalência de parafusos soltos e fraturados durante a função destas coroas. Um modelo de elemento finito bidimensional foi usado para esta investigação, o modelo para analise é de um implante de 3,75 x 10mm de titânio (fixação) um abutment de titânio parafusado de $4 \mathrm{~mm}$, um cilindro de ouro $3 \mathrm{~mm}$ com cabeça plana e um parafuso de ouro com uma fenda, a coroa simulava um desenho de pré-molar para a realização da análise de contato não linear. Efetuou-se uma simulação de um torque de $10 \mathrm{Ncm}$ parafuso de fixação seguido por colocação de uma carga de $487.2 \mathrm{~N}$, na ponta de cúspide para ocorrer a separação do contato entre (1) parafuso de ouro e pilar, (2) a coroa e pilar. Com a repetição dos ciclos de carga e descarga alternados resultou em separação do contato entre o parafuso, pilar e coroa. A conclusão foi que os fracassos provavelmente possam ser resultado da separação dos componentes devido às tensões elevadas nos parafusos.

Em 1993, WEINBERG ${ }^{114}$ ressaltou as diferenças entre os aspectos biomecânicos da distribuição de forças em próteses implanto-suportadas e dento- 
suportadas. As diferenças na rigidez relativa das estruturas envolvidas, o meio de sustentação (osseointegração e ligamento periodontal), assim como o relacionamento complexo entre os componentes do sistema são responsáveis pela absorção e distribuição de forças. A distribuição de forças nas próteses dento-suportadas depende da estrutura rígida do dente e da prótese, contando ainda com a resiliência do ligamento periodontal. Nas próteses sobre implantes, a distribuição das forças, dependem do grau de deformação dos parafusos do intermediário, da própria prótese, do implante e do tecido ósseo, uma vez que a osseointegração não conta com a presença do ligamento periodontal. Portanto, nas próteses sobre implantes, a distribuição de forças é consideravelmente restrita. Enquanto o ligamento periodontal tem uma resiliência de aproximadamente $500 \mu \mathrm{m}$, a parte mais flexível do sistema de implantes permite uma deformação máxima de $100 \mu \mathrm{m}$. Quando não se estabelece uma pré-carga suficiente e/ou uma adaptação adequada entre o intermediário e o cilindro de ouro, o parafuso de ouro pode sofrer deformação ou fratura. O estabelecimento da pré-carga nessa interface, com o apertamento adequado do parafuso, com torque de $10 \mathrm{Ncm}$, pode minimizar a força de cisalhamento que ocorre sobre ele. Entretanto, quando existe uma desadaptação na interface intermediário / cilindro de ouro, a força de cisalhamento gerada no parafuso pode ser maior do que ele é capaz de suportar, podendo causar a fadiga do metal e até sua falha. Em uma prótese unitária, o afrouxamento ou falha do parafuso de ouro é facilmente detectável. Em uma prótese extensa, a falta de adaptação e a subseqüente falha do parafuso alteram a distribuição da força oclusal para outros pontos onde há uma interface e uma pré-carga adequadas e é difícil de detectar. Conseqüentemente, os outros implantes podem ser sobrecarregados, 
principalmente se essa falha ocorrer no implante distal de uma prótese com extensão em cantilever.

KOHAVI $^{62}$, em 1993, comentou algumas complicações relacionadas aos componentes de próteses implanto-suportadas observadas em sua experiência clínica. Observou que a falta de adaptação passiva entre a prótese e o intermediário e os contatos oclusais deletérios são os principais responsáveis por complicações. Contatos oclusais inadequados podem gerar uma sobrecarga ou um momento de torção na prótese, causando o afrouxamento ou fratura de um dos componentes do sistema.

Em um estudo multi-centro realizado em 1994, LANEY et al. ${ }^{64}$, relataram que após 3 anos de acompanhamento, 82 pacientes dos 92 iniciais que possuiam restaurações de dentes isolados sustentada por implante Bränemark, $100 \%$ destas restaurações sobreviveram. Em um ano de acompanhamento 6 pacientes perderam o tratamento caindo para 88 a porcentagem de sucesso sendo então 97,2\% e entre os 3 anos de acompanhamento este índice caiu para 82 o número de pacientes com sucesso, sendo uma taxa acumulativa de 3 anos num total de 97,2\%. Não foram observadas alterações como gengivite, profundidade de bolsa, índice de sangramento da e mobilidade dentária ou de implantes daquelas relatadas após 1 ano. A reabsorção óssea marginal permaneceu em um nível baixo, menos de $0.1 \mathrm{~mm}$ anualmente durante o segundo e terceiro ano. 0 afrouxamento do parafuso do pilar da conexão continuou, mas em uma taxa significantemente reduzida daquela relatada após 1 ano, quando este parafuso de pilar de conexão era de ouro em vez de titânio, permanecendo preso.

Analisando os parâmetros clínicos para avaliar a adaptação passiva da prótese implanto suportada, GYLLENRAM ${ }^{43}$, em 1994, comentou que qualquer 
desadaptação gera forças estáticas que vão atuar sobre todo o conjunto prótese/intermediário/implante e esses efeitos negativos serão acentuados, quando as forças dinâmicas da mastigação atuarem sobre esse mesmo conjunto. Em um osso mais resistente, um certo grau de desadaptação pode ser melhor tolerado que em um osso esponjoso, assim como na região posterior da maxila, que além de menos volumoso, também é sujeito a maiores forças durante a mastigação. A desadaptação pode ser de 3 tipos: vertical, horizontal e angular. Em uma boa moldagem existe a possibilidade de um erro de $50 \mu \mathrm{m}$ nos três tipos de desadaptação.

Em uma edição especial da "International Journal of Oral Maxillofacial Implants" em 1994, sobre assuntos relacionados à adaptação de próteses sobre implantes YANASE $^{116}$ relatou a opinião de vários autores, os quais descreviam como realizavam os testes de adaptação da infra-estrutura de uma prótese fixa. Segundo JEMT, a verificação da adaptação da infra-estrutura é um dos procedimentos mais críticos durante a confecção de uma prótese implantosuportada, pois nenhuma fundição apresentará uma adaptação completamente passiva micrometricamente. Ele ressaltou que a adaptação deve ser observada em um nível clinicamente aceitável, onde pequenas interfaces ou fendas entre a peça fundida e os implantes, antes do aperto dos parafusos, podem ser aceitas. GULBRANSEN, por sua vez, ressaltou que as possíveis fontes de imperfeições inerentes aos procedimentos de confecção da prótese devem ser observadas, como os procedimentos de transferência, de inclusão e fundição, as propriedades das ligas e dos materiais de moldagem e, ainda, as características dos componentes de implantes utilizados. PAREL salientou que é impossível a obtenção de uma adaptação realmente passiva, apesar de se dispor de vários 
métodos para melhorar os procedimentos de fundição e da confecção da prótese como um todo. Sugeriu que a inspeção visual e o apertamento do parafuso são as melhores formas de se avaliar a adaptação, ao se apertar o parafuso mais distal de um lado e observar a adaptação do outro lado da peça. Esta técnica é facilmente realizada, tanto no laboratório como clinicamente, embora não seja possível ser observada quando a interface está localizada subgengivalmente. Neste caso, o autor recomenda observar a quantidade de voltas necessárias para apertar o parafuso e, caso um parafuso exigir mais voltas, pode indicar um desajuste vertical. Os autores ressaltaram, ainda, a necessidade de verificação da fidelidade do modelo obtido e consideraram esse procedimento fundamental para a obtenção de uma peça bem adaptada e para permitir a verificação da adaptação já no próprio modelo.

Segundo CARLSSON; CARLSON ${ }^{21}$, em 1994, uma prótese com adaptação passiva significa que esta pode ser parafusada sem causar estresse ou tensão. Porém ressaltaram que não existe uma adaptação absolutamente passiva já que todo aperto de parafuso gera uma certa deformação da prótese e/ou do osso, induzindo algum estresse ao sistema. O estresse e tensão são a conseqüência de uma prótese mal adaptada e são fatores que afetam a longevidade dos componentes. Sugeriram duas formas de medir o grau de desadaptação de um sistema: medindo as forças introduzidas durante o aperto dos parafusos, ou através da medida de extensão da desadaptação por meio de um microscópio de medição. O autor salientou que devido às características do

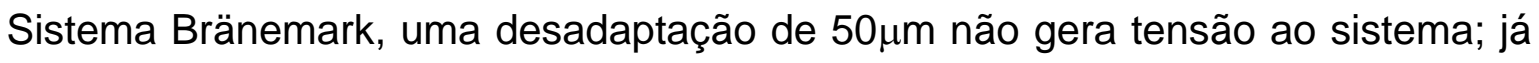
uma desadaptação angular de mesmo tamanho pode gerar um deslocamento angular no ápice do implante para aliviar a tensão gerada. A precisão de 
adaptação entre o intermediário do implante e o componente protético da infraestrutura tem sido questionada como um fator significante na transferência do estresse, na biomecânica dos sistemas de implante, na ocorrência de complicações e resposta dos tecidos na interface biológica.

Em 1994, EKFELD; CARLSSON; BORJESSON ${ }^{32}$ realizaram uma avaliação clínica de restaurações unitárias suportadas por implantes Bränemark, durante um período de 14 a 55 meses. As restaurações permaneceram em função de 3 a 46 meses, média de 18 meses. Em 77 pacientes foram colocados 93 implantes para confecção de próteses unitárias, sendo que duas fixações foram perdidas, uma antes da conexão do implante com o pilar, e outra durante o primeiro ano em função. Observaram que a complicação protética mais comum foi o afrouxamento do parafuso do pilar, o qual ocorreu em 43\% das restaurações, sendo que em 28 restaurações os parafusos afrouxaram uma vez e, em 12, duas ou mais vezes. Dois parafusos tiveram que ser trocados durante os primeiros dois anos devido ao afrouxamento do parafuso sob coroas permanentemente cimentadas. Concluíram que as restaurações unitárias sobre implantes oferecem uma alternativa de tratamento promissor, com excelentes resultados biológicos, estéticos, e funcionais, enquanto que o método de fixação precisa de alteração para diminuir o afrouxamento do parafuso.

Em um estudo retrospectivo, BECKER; BECKER, ${ }^{10}$ em 1995, apresentaram os resultados de restaurações unitárias suportadas por implantes substituindo molares mandibulares e maxilares. Vinte e dois pacientes (16 mulheres e seis homens) receberam 24 implantes que foram acompanhados por um período médio de 24 meses. Vinte e um dos implantes tinham um diâmetro de $3,75 \mathrm{~mm}$, 1 de $4 \mathrm{~mm}$ e 2 de $5 \mathrm{~mm}$, sendo 18 implantes mandibulares e seis 
maxilares. Restaurações foram realizadas e fixadas utilizando-se parafusos de ouro. Duas semanas após a inserção das coroas, os parafusos foram reapertados. A oclusão de todas as restaurações foi desenvolvida minimizando contatos cêntricos e interferências laterais. O índice acumulado de sucesso foi de 95,7\% após um ano. Afrouxamento dos parafusos de retenção ocorreu em oito implantes (38\%), sendo que 14,2\% afrouxaram uma vez, 9,5\% duas vezes e 14,3\% três vezes. Fratura do parafuso do pilar ocorreu em um paciente, e nenhuma fratura da coroa ou implante ocorreu. O índice de sucesso foi relacionado a diversos fatores: qualidade e quantidade óssea adequada, comprimento o mais longo quanto anatomicamente possível e exclusão dos pacientes com hábitos parafuncionais, já que foram descritos como fator de risco relacionado à fratura do implante e perda do parafuso de ouro devido à incidência de forças excessivas. Os autores acreditam que a alta incidência de afrouxamento do parafuso de ouro (38\%) pode ser diminuída com a utilização do pilar ceraone.

HASS et al. ${ }^{44}$, no mesmo ano, reportaram experiências de 76 restaurações unitárias suportadas por implantes Bränemark, colocadas em 71 pacientes (35 mulheres e 36 homens). Os implantes foram restaurados com os pilares unitários originais (Nobelpharma AB), e com o pilar ceraone. Dois implantes $(2,63 \%)$ foram removidos durante todo o período, sendo relatada uma sobrevivência de 96,3\% após 66 meses. A complicação protética mais comumente observada foi o afrouxamento do parafuso do pilar, o qual ocorreu em 12 restaurações, e foi observada em alguns meses após a instalação das restaurações; entretanto foi possível reduzir essa ocorrência de afrouxamento aplicando um torque definido. Parâmetros periimplantares foram investigados em 56 implantes que estavam instalados por mais de um ano. A função aceitável do implante foi demonstrada 
com parâmetros clínicos e radiográficos preestabelecidos e apresentados os resultados durante seis anos. Parâmetros clínicos de índice de placa simplificado, índice gengival, profundidade de bolsa, mobilidade, também foram avaliados, permanecendo os mesmos estáveis depois de um ano. Os autores concluíram que, com os resultados clínicos e estéticos obtidos, as restaurações unitárias suportadas por implantes podem ser recomendadas.

MILLINGTON; LEUNG ${ }^{79}$, em 1995, avaliaram um estresse natural gerado sobre um implante quando uma infra-estrutura apresenta um plano impreciso de desadaptação. Foi confeccionada uma barra de latão reta, de 20mm de diâmetro, onde foram instaladas 4 réplicas do implante 10mm (SDCS 001, Nobel-pharma, Gotemburgo, Suécia). A infra-estrutura foi confeccionada em ouro tipo IV. Um modelo fotoelástico (OS-1, Measurements grup Uk Ltda, Basingstoke, UK) foi utilizado. Para fixação da barra, foram usados parafusos de ouro e abutment transmucoso com torque de $10 \mathrm{Ncm}$. Para estabelecer o tamanho da fenda gerado, a superfície da infra-estrutura foi monitorada por um transdutor antes e depois da introdução da infra-estrutura; e para marcar o estresse, gerado utilizouse um polariscópio, usado para obter as medidas do estresse aonde foi ligado a 12 pontos ao longo da lateral da infra-estrutura. A distribuição do estresse foi registrada por fotografias da margem do modelo. Um efeito de 9 discrepâncias foi testado separadamente no abutment final (D) e entre o abutment C e D. Os autores concluíram que o estresse era maior no abutment do que no meio, entre os abutments, relacionando com a infra-estrutura parafusada a $10 \mathrm{Ncm}$, e que a desadaptação era menor na região do abutment do que no meio, entre os abutments, e foi em torno de $6 \mu \mathrm{m}$ (o estresse induziu a uma desadaptação pequena, quando o parafuso era apertado). 
O afrouxamento do pilar de conexão é um problema associado a restaurações de implantes unitários. Os fabricantes de implantes têm tentado solucionar esse problema com a introdução de características que impedem movimentos rotacionais aos seus sistemas. DIXON et al. ${ }^{30}$, em 1995, investigaram in vitro os níveis de micromovimentos e torque necessário para causar o afrouxamento de pilares de conexão em combinações de implantes com pilares de conexão retos e angulados de três fabricantes. Cada amostra foi submetida a movimentos recíprocos horizontais de compressão, numa inclinação antes e após o teste, e também foi registrada e comparada para cada sistema. Os resultados não indicaram diferenças significativas entre todos os pilares de conexão retos e angulados para movimentos de rotação, deflexão e para o torque necessário para causar o afrouxamento dos pilares de conexão. Os autores sugerem que as pequenas variações no torque necessárias para causar o afrouxamento dos pilares de conexão, medidas após uma função simulada para todos os três sistemas de implantes avaliados, não foram grandes o suficiente para causar a perda da conexão pilar de conexão/ implante e, portanto, não teriam significado clínico.

JEMT et al. ${ }^{55}$, em 1996, preocupados em desenvolver sistemas fiéis e reproduzíveis para avaliar e mensurar a adaptação dos componentes de implantes, levaram alguns centros a desenvolverem os resultados de seu próprio sistemas de medição. Os autores apresentaram os resultados dos métodos e sistemas desenvolvidos para mensurar a adaptação na interface componente/intermediário. Esse estudo foi realizado em 4 centros dos Estados Unidos e Suécia por um período de 2 anos. Foram desenvolvidos 4 sistemas de medição, todos capazes de fornecer dados tridimensionais que quantificam as 
relações linear e angular. Todos os sistemas são ligados a computadores com programas para transformações geométricas, análises estatísticas e resumo diretamente em gráficos. Após todas as análises, concluíram que há diferenças e que é importante que sejam desenvolvidos métodos precisos e confiáveis de avaliação devido à importância clínica do fator adaptação protética.

Infelizmente, é pequena a quantidade de dados para avaliar a discrepância marginal entre o cilindro e um abutment. CHESHIRE; HBKIRK ${ }^{26}$, em 1996, propuseram um estudo para investigar clinicamente a adaptação da infraestrutura, julgando estar satisfatória para o dentista e confortável para o paciente. A adaptação de 5 infra-estruturas entre abutment transmucoso foi investigada in vivo, usando um material de impressão para registrar as discrepâncias. As discrepâncias vertical e horizontal foram analisadas usando um microscópio e foram marcadas quando os cilindros de ouro eram apertados com a mão e quando eram apertadas pelo controlador de torque (Nobel Biocare) a 10Ncm, que é o valor recomendado. As restaurações foram retiradas do abutment transmucoso e limpas, depois foram colocadas novamente e apertadas, um grupo com a mão e o outro com o torquímetro. Colocou-se primeiramente o material leve de moldagem e depois o de média densidade ao redor do abutment e das infra-estruturas. A discrepância vertical para os abutments apertados com a mão variou de $0-63 \mu \mathrm{m}$, média $14 \mu \mathrm{m}$. O grupo que foi apertado mecanicamente variou de $0-130 \mu \mathrm{m}$, média $21 \mu \mathrm{m}$. A discrepância horizontal com o torquímetro variou de

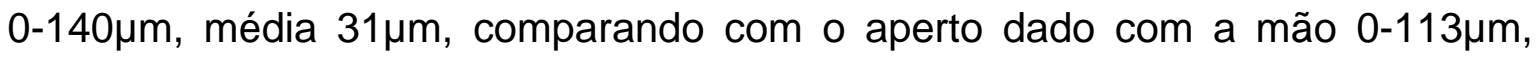
média $46 \mu \mathrm{m}$. Uma adaptação ideal é raramente obtida. Uma discrepância existe ao redor das infra-estruturas, a qual pode ser aceita ou não clinicamente, porém o aperto do parafuso de ouro com a mão reduziu a discrepância vertical. 
ARBER; ZARB ${ }^{3}$, em 1996, relataram a efetividade clínica de restaurações unitárias suportadas por implantes no sistema Bränemark. Trinta e oito pacientes com 42 implantes foram acompanhados, por um período de um a oito anos. As restaurações foram realizadas incluindo pilares standards anti-rotacionais, angulados e ceraone; com parafuso de ouro ou de titânio com cabeça hexagonal ou de fenda. Avaliações foram realizadas após a carga em uma semana, 6 e 12 meses e anualmente até o último controle. Em cada avaliação, as coroas foram removidas, cada implante foi avaliado clínica e radiograficamente e complicações protéticas também foram registradas. No último controle, foi aplicado um questionário para avaliar o grau de satisfação do paciente com o tratamento, obtendo-se $94 \%$ de aceitação. Todos os implantes permaneceram estáveis, porém afrouxamento do parafuso da coroa ou do pilar foi a complicação protética mais comum, sendo que isso ocorreu com mais freqüência nos parafusos de titânio do pilar. Quando estes foram trocados por parafusos de ouro e apertados com o controlador de torque Nobelpharma, essa ocorrência diminuiu. Fratura do parafuso de titânio do pilar ocorreu em dois pacientes e em outras cinco coroas ocorreu fratura da cerâmica.

Em um estudo de acompanhamento clínico, BALSHI et al. ${ }^{5}$, no mesmo ano, avaliaram 47 pacientes tratados com implantes Bränemark para substituição da perda de um molar. Os pacientes foram divididos em dois grupos, sendo que 22 restaurações foram realizadas utilizando um implante grupo 1, e 25 com dois implantes grupo 2. Dos 72 implantes colocados, 66 (92\%) foram na mandíbula e 6 (8\%) na maxila. A seleção dos pacientes para colocar um ou dois implantes foi realizada baseada na largura interdental do espaço edêntulo. Em pacientes com espaço maior a $12 \mathrm{~mm}$, dois implantes foram colocados e em pacientes com 
espaço menor, um implante foi utilizado. O material restaurativo utilizado foi porcelana fundida sobre ouro, e a função oclusal foi estabelecida utilizando contatos cêntricos firmes e pouca pressão nos movimentos excursivos. Essa condição foi controlada e ajustada a cada seis meses se fosse necessário. Em cada visita, a mobilidade da prótese foi avaliada. Durante o primeiro ano de função um implante foi perdido, com uma percentagem de sucesso de 99\%; entre o segundo e terceiro ano nenhum implante foi perdido, com $100 \%$ de sucesso. A mobilidade da prótese ou afrouxamento do parafuso foi a complicação mais freqüente (48\%), predominando no grupo 1 com restaurações suportadas por um implante; no grupo 2, onde as restaurações foram suportadas por dois implantes, essa complicação foi substancialmente reduzida (8\%). Os problemas mecânicos das restaurações utilizando um implante foram diminuídos utilizando uma união mais forte com os pilares ceraone, sendo que todos os oito pilares deste tipo utilizados permaneceram estáveis; enquanto que todas as fraturas e afrouxamento ocorridos apareceram no pilar standard (Nobelpharma AB). Com os resultados desse estudo, os autores sugerem que a terapia de substituir um molar utilizando implante pode ser efetiva e confirmam que essa substituição proporciona maiores vantagens biomecânicas quando são utilizados dois implantes.

No ano seguinte BALSHI et al. ${ }^{6}$, em um estudo multicentro, investigaram a sobrevivência de implantes osseointegrados (Nobel Biocare) quando conectados a pilares convencionais ou angulados, sendo observadas as alterações periimplantar e protéticas por um período de três anos. Sessenta e três próteses fixas maxilares e dez mandibulares foram colocadas em 71 pacientes, pilares angulados ou uma combinação de pilares convencionais e angulados foram 
utilizados para suportar as próteses. Dos 425 implantes colocados inicialmente, quatro falharam antes da conexão com o pilar; dos 421 remanescentes, 209 foram conectados a pilares angulados e 212 a pilares convencionais. Os pilares angulados utilizados no estudo foram de $30^{\circ}$ com alturas máximas de $4 \mathrm{~mm}$ e mínima de 1,5mm. As 73 próteses fixas corresponderam a 44 próteses completas, 25 próteses parciais, duas próteses conectadas a implantes e dentes naturais e duas próteses unitárias. Cinco e três por cento dos implantes com pilares angulados e 7,5\% com pilares convencionais falharam. O sucesso das próteses foi de $96,8 \%$, na maxila, e $100 \%$ na mandíbula, sendo que as complicações encontradas no estudo incluíram fraturas do material oclusal em três pacientes, fratura da infra-estrutura em outros três pacientes e, após os três anos de estudo, quatro parafusos do pilar precisaram ser reapertados em 3 pacientes. As avaliações das alterações periimplatar indicaram que os pilares angulados não necessariamente promovem alterações. Os autores concluíram que o comportamento clínico dos pilares angulados pode ser comparado ao dos pilares convencionais como uma modalidade previsível na reabilitação protética.

DELLOW; DRIESSEN; NEL ${ }^{29}$, em 1997, utilizaram microscopia eletrônica de varredura (MEV) para investigar a adaptação da interface pilar / implante de quatro sistemas diferentes de implantes, assim como para determinar a adaptação dessa interface quando os componentes são intercambiados. Os sistemas Southern Implants, Bränemark, Swede-Vent, e Steri-Oss foram utilizados; quatro implantes e quatro pilares de cada sistema foram avaliados. Os implantes / pilares foram agrupados em todas as possíveis combinações. Cada combinação foi montada em uma placa de alumínio para colocação dentro do MEV. Medidas foram realizadas aleatoriamente em três áreas selecionadas da 
interface. As circunferências das conexões foram observadas e avaliadas seguindo os seguintes critérios: (1) Valores do espaço vertical entre implante e pilar (microfenda) do mesmo sistema para controle, assim como para as combinações intercambiadas. (2) A formação de espaço horizontal (sobrecontorno) entre o implante e o pilar, do mesmo sistema, assim como para as combinações intercambiadas, relacionando-as de forma positiva ou negativa aos implantes. Os resultados relataram não existir diferenças estatisticamente significantes entre os pilares e os sistemas de implantes testados, em relação à microfenda. Diferenças estatisticamente significantes foram encontradas em relação ao sobrecontorno, entre os pilares e em cada um dos implantes utilizados. Os valores da microfenda para os grupos controles de todos os sistemas avaliados indicaram claramente que todos os sistemas têm excelentes tolerâncias de usinagem, com valores de microfenda de 0 a 7,15 $\mu \mathrm{m}$. Os sistemas SwedeVent e Southern mostraram os menores valores de microfenda, seguido do SteriOss. Em relação ao sobrencontorno, o sistema Bränemark mostrou o maior sobrecontorno de todos os sistemas avaliados.

Em um estudo in vitro, JANSEN; CONRADS; RICHTER ${ }^{50}$, em 1997, determinaram a infiltração microbiana na interface implante/pilar de diferentes sistemas de implantes. Em treze combinações de nove sistemas diferentes, foram realizados testes microbiológicos nos quais a penetração da bactéria Escherichia coli na área da interface implante/pilar foi observada. Os desenhos dos sistemas testados foram diferentes em vários aspectos, como na forma da interface as quais foram cônicas e planas; pilares de uma parte e de várias partes conectados aos implantes por parafusos separados. Dez amostras de cada sistema foram testadas sob condições estéreis; a parte interna do implante foi inoculada com 
uma suspensão de Escherichia coli, que é uma bactéria móvel gram negativa que mede 1,1 a $1,5 \mu \mathrm{m}$ de diâmetro e 2,6 $\mu \mathrm{m}$ de extensão. As amostras foram colocadas em tubos de ensaio contendo uma solução nutriente e armazenadas a $37^{\circ}$ C. Nos dias 1, 2, 5, 7, 10 e 14, uma possível penetração da bactéria na solução circundante foi avaliada. Essa penetração causou colonização bacteriana e resultou em uma solução turva. Na maioria dos sistemas de implantes, os componentes da conexão resultaram em apenas alguns casos de contaminação na porção externa; entretanto, para os sistemas Ankylos e Astra, a suspensão bacteriana invadiu a parte externa em mais da metade das amostras. Em uma segunda parte do estudo, uma amostra de cada tipo foi aleatoriamente selecionada e analisada no microscópio eletrônico de varredura (MEV) e a adaptação marginal entre o implante e o pilar foi medida em 12 áreas, com um aumento de $775 \mathrm{X}$. Os resultados mostraram que as fendas marginais de todas as partes pré-fabricadas foram menores de $10 \mu \mathrm{m}$ e que somente o pilar Octa mostrou fenda máxima de $12 \mu \mathrm{m}$. O valor médio esteve abaixo de $5 \mu \mathrm{m}$ para todos os sistemas. Os autores concluíram que os sistemas de implantes comuns não podem prevenir a infiltração microbiana e a colonização bacteriana da parte interna do implante, sendo que há necessidade de modificações para selar a área de contato implante / pilar. Uma solução promissora é a arruela de silicone do pilar Frialit-2, o qual claramente reduz a infiltração quando comparado aos outros pilares convencionais.

Neste mesmo ano, HEBEL; GAJJAR $^{45}$ discutiram a influência da estética e da oclusão na seleção do uso de sistemas parafusados ou cimentados, como retenção para próteses sobre implantes. Para os autores, um dos argumentos mais utilizados pelos defensores das próteses parafusadas é o de dar condição 
da prótese ser reutilizável, mas que quando é selecionado um cimento adequado a prótese cimentada também se torna reutilizável. Desvantagens importantes como a de instabilidade do parafuso são encontradas nas próteses parafusadas. Quando uma força vertical ou oblíqua atua sobre a prótese, produz-se tensão no parafuso, o que provoca instabilidade ou afrouxamento do mesmo. O desenho da oclusão na prótese também se torna prejudicado pelo orifício de acesso do parafuso. Já que se é considerado que o diâmetro dos parafusos é de $\pm 3 \mathrm{~mm}, 0$ orifício de acesso será também de $\pm 3 \mathrm{~mm}$, o que representa no mínimo $50 \%$ da mesa oclusal de molares e mais de $50 \%$ em pré-molares. Esta área pode ser crítica para se obter uma ótima oclusão e, como conseqüência, a estética também será afetada. As vantagens das próteses cimentadas tornam-nas um mecanismo viável uma vez que proporcionam passividade, quando existem discrepâncias nas infra-estruturas, e podem ser ajustadas com procedimentos de rotina no consultório odontológico. A ausência de orifícios aumenta a resistência nas propriedades físicas das cerâmicas ou das resinas. Melhoram o acesso ao setor posterior da boca, reduzem custos, complexidade de componentes e de procedimentos laboratoriais, além de reduzir o tempo clínico, tendo como resultado uma estética superior.

LEVINE et al. $^{70}$, em 1997, avaliaram a sobrevivência de implantes ITI quando utilizados para restaurações unitárias. Compararam coroas cimentadas e parafusadas observando as complicações protéticas associadas. Cento setenta e quatro implantes foram colocados em 129 pacientes, em 12 centros clínicos nos Estados Unidos. As restaurações estiveram em função por um mínimo de seis meses (média de 12 meses) e foram localizadas na região posterior (151 restaurações) e na região anterior (23 restaurações), sendo que 110 foram 
localizadas na mandíbula e 64 na maxila. Em 92 implantes foram colocadas restaurações parafusadas utilizando pilares (octa), e em 82 as restaurações colocadas foram cimentadas utilizando um pilar solid conical abutment. Avaliação periodontal e complicações protéticas foram registradas. Observou-se 97,7\% de sobrevivência dos implantes em seis meses de carga. Afrouxamento do parafuso de retenção foi encontrado em oito de 92 implantes restaurados com coroas parafusadas (8,7\%). Destes dois estavam colocados no setor anterior e seis no setor posterior. Em restaurações cimentadas, ocorreu afrouxamento de três pilares $(3,7 \%)$ colocados em um paciente no primeiro molar superior direito e esquerdo, e no primeiro molar mandibular esquerdo. $\mathrm{O}$ autor acredita que $\mathrm{O}$ desenho cônico interno com componente anti-rotacional desse sistema, unido à aplicação de um torque de $35 \mathrm{Ncm}$, oferece um comportamento mecanicamente favorável à interface durante as cargas funcionais; por isso a baixa incidência de afrouxamento do parafuso do pilar $(3,6 \%)$. No caso do parafuso oclusal, onde 8,7\% de afrouxamento ocorreu, o autor sugere que a configuração cônica do pilar amortece o sistema da vibração e micromovimento durante a função, já que em nenhum caso o parafuso afrouxou em mais de uma vez, o que sugere que a força de aperto deve ser verificada após a restauração estar em função.

Percussão, observação visual, radiografias periapicais convencionais são os métodos mais freqüentes usados para avaliar a exatidão entre a adaptação de componentes protéticos e implantes, porém esses métodos são limitados. Neste estudo MAY et al. ${ }^{76}$, em 1997, utilizaram um instrumento para avaliar a interface entre abutment e cilindro de ouro chamado Periostite (PTV). Para isso, foram utilizado 2 costelas bovinas que receberam 3 implantes self-tapping Bränemark e abutments (SDCA005) $5.5 \mathrm{~mm}$ foram parafusos a $20 \mathrm{Ncm}$ pelo Controlador de 
torque Nobelpharma aos implantes. Foram realizadas uma série de radiografias desses conjuntos e o Perioteste então foi colocado nos 6 abutments e 6 medidas foram realizadas para cada abutment, num total de 36 . Instalou-se um cilindro de ouro individual em cada abutment, de 4.0mm (DCA 072), com torque de $10 \mathrm{Ncm}$. Foi feita uma série radiográfica e o Periostite foi colocado em cada cilindro e realizadas as medidas. O abutment e o cilindro foram removidos e os implantes preparados para incorretas instalações. Três diferentes espessuras foram criadas: $5,4 \mu \mathrm{m}, 50,8 \mu \mathrm{m}$ e $101,6 \mu \mathrm{m}$. Depois foram instalados os abutments e os cilindros e foram realizadas as mesmas medidas. A média dos valores do Periostete de adaptação dos abutments sobre os implantes foi $60 \pm 0,32 \mu \mathrm{m}$ e abutment cilindro $(3,4 \pm 0,32)$. O desajuste à interface entre o implante e o abutment resulta em um valor mais negativo, tendenciando a $\mathrm{N}=0,54$, com aumento da espessura; e entre o abutment e cilindro de ouro o valor foi de $N=0,72$. Os autores indicam a utilização do Perioteste para avaliar a adaptação entre implantes/abutment e abutment/cilindro de ouro.

Em 1998, KANO ${ }^{47}$ avaliou a adaptação na interface pilar / cilindro de ouro utilizando-se componentes do mesmo sistema e combinações de componentes de diferentes sistemas. Seis conjuntos de implantes compatíveis foram utilizados: 3i, Lifecore, Conexão, Implamed, Nobel Biocare e NAPIO. Cada implante foi montado em um bloco de resina acrílica autopolimerizável, o qual foi conectado um pilar convencional standard com um torque de $20 \mathrm{Ncm}$. Sobre este, foram fixados os cilindros de ouro dos diferentes sistemas, com a aplicação de um torque de $10 \mathrm{Ncm}$. Cada conjunto foi levado a um microscópio comparador com cabeçotes micrométricos digitais (Mitutoyo TM - modelo 5050), onde foi avaliada a interface em oito sítios diferentes. Os resultados da análise intra-sistema, 
mostraram que não houve diferenças estatisticamente significantes em relação ao

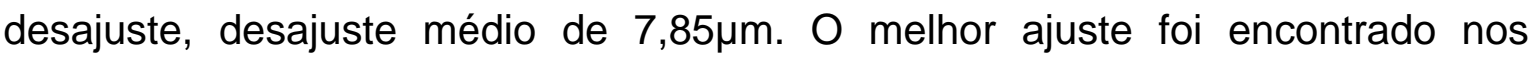
sistemas Nobel Biocare e Implamed e o pior, nos sistemas Lifecore e 3i. Os resultados das análises entre sistemas encontrados sugeriram que nem todas as combinações podem ser consideradas compatíveis.

JEMT $^{54}$, em 1998, realizou um estudo onde descreveu uma técnica alternativa para fabricação de coroas unitárias sob implantes, usando um abutment de titânio com a aplicação da porcelana direto no abutment. O teste foi composto por 14 pacientes selecionados (Bränemark Clinic, Goterborg, Swedew), e um total de 17 coroas unitárias foram instaladas. Foram utilizados intermediários tipo standard (DCA 099, Nobel Biocare). Depois da fabricação do modelo mestre, os componentes utilizados foram torneados manualmente com o término em chanferado acompanhando o contorno da gengiva, terminando quase 1 a $2 \mathrm{~mm}$ subgengival. Então foi aplicada a porcelana indicada para o titânio (Procera Nobel Biocare) diretamente no cilindro do abutment. As coroas apresentavam um acesso na lingual ou oclusal para serem parafusadas ao abutment com parafuso de ouro (DCA 118, Nobel Biocare) usado para reter o abutment ceraone. As coroas foram acompanhadas após um mês de instalação, e após 1 ano, observando-se a estabilidade, condição do tecido mole e a oclusão. Durante o $1^{\circ}$ ano de função, apenas um parafuso de ouro soltou, um paciente apresentou-se com fístula. O restante dos pacientes não apresentaram nenhum problema. $O$ autor concluiu que o presente estudo é valido para próteses sob implantes unitárias, pois os procedimentos clínicos são simples, e também a desconexão e a reconexação para algum reparo justificam o uso clínico. 
BYRNE et al. $^{20}$, em 1998, relataram a insuficiência de informação a respeito da adaptação do abutment ao implante. Então os autores propuseram-se a observar a adaptação de abutments pré-usinados, fundidos, e pré-usinados modificados em laboratório em duas condições: interface do abutment e implante e assentado por parafuso de ouro no interior do abutment e na base do abutment. Seis combinações de abutments e implantes contribuíram para este estudo:

Grupo 1: implante Nobelpharma e abutment CeraOne com torque de $32 \mathrm{Ncm}$ do parafuso de ouro sem o ciclo de queima de porcelana;

Grupo 2: $\quad$ implante 3i abutment STR parafuso para fixação de ouro a $32 \mathrm{Ncm}$ sem queima da porcelana;

Grupo 3: $\quad$ implante 3i abutment UCLA de padrão plástico aperto com parafuso de ouro $20 \mathrm{Ncm}$ com ciclo de queima da porcelana;

Grupo 4: $\quad$ implante Nobelpharma, abutment UCLA de padrão plástico parafuso de ouro torque $20 \mathrm{NCm}$ com ciclo da queima da porcelana;

Grupo 5: $\quad$ implante 3i, UCLA pré-usinado parafuso de ouro com 32Ncm com o ciclo da queima da porcelana;

Grupo 6: implante 3i abutment UCLA pré-usinado com parafuso de ouro torque $32 \mathrm{Ncm}$ sem a queima da porcelana.

Para os grupos 3, 4 e 5 foi feito um enceramento de um UCLA e confecção de uma matriz de silicone, para o enceramento uniforme das outras amostras. Então a cera era derretida e injetada por um canal na matriz que estava sobre UCLA parafusado a um análogo de implante, sendo as amostras fundidas com liga de ouro/paládio (PC3, PHOENIX, SHANNON Inc.). Os grupos 3, 4 e 5 fundidos foram preparados e sujeitos a passar pelo ciclo da queima da porcelana. Os abutments foram parafusados aos implantes e presos a uma base de resina. 
O conjunto foi seccionado na direção horizontal no meio do conjunto abutment implante e levados para análise em um microscópio (Mitutoyo Corporation Japan a $\mathrm{x}$ 100). Foram 5 amostras por grupo. As medidas das fendas externas dos

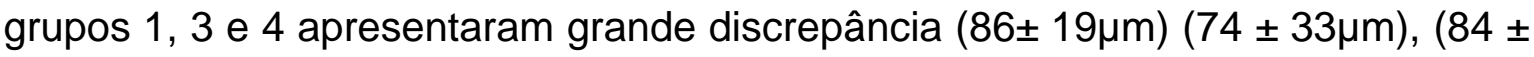
$26 \mu \mathrm{m})$. As medidas verticais foram: grupo $1-35 \pm 17 \mu \mathrm{m}$, grupo $2-15 \pm 16 \mu \mathrm{m}$, grupo 3- $68 \pm 44 \mu \mathrm{m}$, grupo $4-66 \pm 33 \mu \mathrm{m}$, grupo 5- $31 \pm 30 \mu \mathrm{m}$ e grupo 6- $17 \pm$ $20 \mu \mathrm{m}$. As maiores desadaptações foram os UCLA de plástico fundidos em ouropaládio. Esse estudo sugere que abutments pré-usinados possuem adaptação superior aos fundidos em laboratório e indica que é necessário um padrão mais refinado para fundições realizadas em laboratório.

Componentes protéticos sobre implantes deveriam ser desenvolvidos, no mínimo, através de uma investigação científica. WATSON ${ }^{112}$, em 1998, em uma revisão de literatura, relatou o número de problemas causados pelos componentes protéticos que estão no mercado e sugere algumas soluções. A restauração sobre implantes unitários tem a obrigação de manter-se exata em relação à posição de rotação da prótese para fornecer uma função satisfatória, mantendo assim os contatos proximais.

O desaperto do parafuso de retenção da prótese ou abutment é a complicação mais freqüente devido à carga mastigatória. A quantidade do torque aplicado é muita $(10,20,30$ e $32 \mathrm{Ncm})$, dependendo da especificação de cada fabricante. Para evitar esse contratempo para o paciente, é recomendado um bom ajuste oclusal e o uso de torquímetros apropriados para o torque exato de que cada sistema necessita. Outra condição necessária é uma adaptação passiva do metal da infra-estrutura. Muitos dentistas ultrapassam o valor do torque do parafuso de retenção de ouro, de 10 para $15 \mathrm{Ncm}$, para dar maior segurança. 
Como são inúmeros componentes protéticos no mercado, o autor concluiu que cada dentista tem que selecionar o abutment mais indicado para cada caso e deve-se respeitar sua escolha. Porém o componente ideal é aquele que irá dar ótimas condições de trabalho tanto clínico como laboratorialmente.

HELLDÉN; DËRAND ${ }^{46}$, em 1998, para minimizar o erro e otimizar trabalhos com adaptação passiva, apresentaram as vantagens obtidas com o método Cresco Ti Precision para execução das próteses em titânio soldadas a laser. Em um modelo fotoelástico, foram colocados 3 implantes (Cresco Ti Systems $A B$ ) de $13 \mathrm{~mm}$ e, sobre estes, foram enceradas 4 próteses a partir dos componentes plásticos. As peças foram incluídas e fundidas em titânio comercialmente puro, através do uso de máquina de fundição. Duas próteses foram submetidas ao método de precisão e as outras duas, não. As próteses não adaptadas foram observadas ao microscópio e foram encontradas interfaces vertical de $70 \mu \mathrm{m}$ e $40 \mu \mathrm{m}$ nos implantes A e B. Foram realizadas análises fotoelásticas e também as cargas exercidas de mecanismo apropriados. Os resultados revelaram cargas associadas às próteses não adaptadas e ausência de cargas estáticas nas próteses adaptadas. No momento de medição das cargas, foram encontrados valores de $41 \pm 4,3 \mathrm{~N}$ nos parafusos para que conseguissem fechar interfaces de $180 \mu \mathrm{m}$ nos implantes distais. Para fechar $30 \mu \mathrm{m}$, foram encontrados valores de $8 \pm 8,0 \mathrm{~N}$. Nas próteses adaptadas, a carga encontrada nos parafusos foi zero. Para interface de $50 \mu \mathrm{m}$, localizadas no implante central, foi encontrada carga de $300 \pm 26 \mathrm{~N}$ no parafuso de ouro. Os autores ressaltam a importância do fato de que os estresses dependem do erro, da dimensão do mesmo, assim como do tamanho da peça e da localização do mesmo. Consideram também que, apesar do efeito do erro estar relacionado a 
outros fatores como, por exemplo, quantidade óssea, há de se lembrar sempre da importância da adaptação da peça na geração das cargas.

ARTZI; DREIANGEL ${ }^{4}$, em 1999, descreveram uma técnica para manter a estabilidade do parafuso de fixação da supra-estrutura protética, baseada no travamento de uma barra hexagonal, no hexágono da cabeça do parafuso. Para a realização da técnica, foram utilizados os seguintes componentes: uma barra de titânio hexagonal, uma cinta de borracha, uma chave hexagonal de 1,27mm e o parafuso de fixação. A barra adaptou-se precisa e firmemente dentro da parte fêmea do parafuso de fixação. Antes de o parafuso ser apertado, foi verificado se a supra-estrutura estava passivamente estabilizada no hexágono externo do implante. A prótese foi posicionada no implante e o parafuso apertado de acordo com o torque recomendado pelo fabricante. Uma radiografia periapical verificou esta posição, depois disto, a barra hexagonal foi inserida dentro do parafuso de fixação, e a cinta de borracha serviu como uma camada de isolamento; isso evitou que a resina composta penetrasse dentro da cabeça do parafuso. Logo após, aplicou-se resina composta que serviu como material de fixação da barra e também para vedar o orifício de abertura para acesso do parafuso. Finalmente cortou-se a barra abaixo do nível oclusal da coroa. Os autores relataram uma avaliação de 120 restaurações unitárias parafusadas, colocadas em 100 pacientes, sendo que 75 dessas restaurações foram colocadas na área de primeiro e segundo pré-molar, 40 na região do incisivo e 15 na região posterior molar. Durante avaliações de seguimento mensais, foi encontrado que todas as restaurações estavam fixas em seu lugar, sendo que todas elas estavam funcionando com sucesso, especialmente as restaurações da região molar com 
planos oclusais extensos e grandes forças oclusais. Nenhum afrouxamento ou fratura do parafuso foi encontrado.

Em uma continuação do estudo retrospectivo de implantes unitários do sistema ITI iniciado em 1999, LEVINE et al. ${ }^{72}$ apresentaram os resultados de mais dois anos de seguimento clínico, comparando a sobrevivência de coroas cimentadas e parafusadas. Dos 174 implantes unitários colocados e avaliados inicialmente, 110 pacientes com 157 implantes se apresentaram para seguimento (média de 40.1 meses). Destes, quatro implantes falharam devido a periimplantites após seis ou mais meses, e outros três implantes falharam devido a fraturas, os mesmos colocados na área de primeiro molar mandibular após 40,3 meses, tendo-se uma sobrevivência de 95,5\%. Dos 157 implantes remanescentes 76 foram restaurados com coroas cimentadas e pilares cilíndricos, e 81 foram restaurados com coroas parafusadas com o pilar octabutment. Os problemas restaurativos com pilares cilíndricos cônicos incluíram uma incidência de afrouxamento de 5,3\%. Apenas uma coroa unida a um pilar octabutment afrouxou após três anos; enquanto que 18 restaurações parafusadas $(22,2 \%)$ tiveram incidência de afrouxamento do parafuso de retenção. Com esses dados, os autores sugerem que o sistema de implantes ITI pode ser utilizado satisfatoriamente para restaurações unitárias do setor posterior da boca.

Em um estudo de dez anos de sobrevivência de implantes unitários, PRIEST $^{87}$, em 1999, avaliou as complicações clínicas envolvendo as restaurações e o estado dos dentes adjacentes em 116 implantes. A sobrevivência foi avaliada desde a colocação do implante até o último exame. Radiografias e fotografias antes do tratamento foram utilizadas para determinar o estado dos dentes imediatamente adjacente ao espaço edêntulo. Noventa e nove pacientes 
receberam 112 restaurações unitária, sendo que 100 dos implantes restaurados 3i, 12 Nobel Biocare, 2 Steri-Oss, 1 Impla Med e 1 Frialtec. O autor restaurou 107 implantes utilizando componentes $3 \mathrm{i}$, e os demais implantes foram restaurados utilizando componentes do fabricante do implante. Componentes diretos e pilares tipo UCLA foram os mais utilizados; nos parafusos de ouro do pilar foi aplicado um torque de $32 \mathrm{Ncm}$, sendo que a restauração parafusada foi a mais utilizada. Cento e nove restaurações foram metalo-cerâmicas e três total-cerâmicas. Oitenta e três implantes foram colocados na maxila e 33 na mandíbula, dos quais 62 implantes foram no setor anterior e 54 no setor posterior. Três implantes falharam em manter a integração, tendo-se uma sobrevivência de 97,4\%. A complicação protética mais comum foi a de afrouxamento dos parafusos, a qual ocorreu em 7,1\% das restaurações. Dissolução do cimento em restaurações cimentadas ocorreu em 5,4\%. Duas restaurações foram perdidas (1,8\%), uma por perda do implante e outra por fratura do parafuso do pilar. Fratura da cerâmica foi encontrada em uma restauração $(0,9)$. Todas as complicações protéticas foram encontradas em 17 pacientes (18,8\%), enquanto os dentes adjacentes à restauração do implante unitário, 79,6\% permaneceram intactos ou minuciosamente restaurados.

SHOLANDER $^{95}$, em 1999, realizou um estudo de avaliação clínica de restaurações unitárias suportadas por implantes do sistema Bränemark. Duzentos e cinqüenta e nove restaurações colocadas em 183 pacientes, com média de 29,8 anos de idade, e colocadas na maxila (89\%) e na mandíbula (11\%) foram avaliadas durante um período de um a cinco anos. Em 208 restaurações (81\%), foram utilizados pilares ceraone, e em 48 (29\%) pilares unitários DCA 085-189; destas, 175 foram restaurações total-cerâmicas (68\%), 79 metalo-cerâmicas 
(30,5\%), e quatro metalo-plásticas (1,5\%). Avaliações clínicas de estabilidade do implante, estética, oclusão, e complicações cirúrgicas e protéticas foram registradas. Das restaurações, 98,5\% permaneceram em função depois de cinco anos de carga. A complicação mais comum foi o afrouxamento do parafuso, que ocorreu em dez restaurações (3,9\%), sendo que o afrouxamento só ocorreu em duas restaurações onde foram utilizados pilares ceraone. O autor acredita que esse tipo de pilar diminui o índice de afrouxamento. Outras oito coroas tiveram que ser refeitas devido a complicações protéticas, enquanto que as condições dos tecidos ao redor das restaurações mostraram-se saudáveis quando comparadas aos dentes adjacentes.

Em 1999, WEE; AQUILINO; SCHNEIDER ${ }^{113}$, com objetivo de encontrar uma adaptação precisa das próteses sobre implantes, realizaram um estudo onde, por meio de uma revisão de literatura, observaram que muitos métodos têm surgido para que aquela aconteça. A maioria dos artigos revisados eram clínicos ou técnicos e mostravam estratégias para melhorar a adaptação das próteses sobre implantes. A maioria das estratégias resultaria em uma pequena interface da infra-estrutura com o intermediário do implante. Muitos fatores impedem que o conceito de adaptação passiva possa ser encontrado nas próteses sobre implantes, mesmo com o uso de estratégias avançadas.

KEITH et al. ${ }^{61}$, ainda nesse ano, avaliaram a magnitude da discrepância marginal da interface prótese/implante, em restaurações parafusadas e cimentadas, utilizando implantes ITI (Straumann). Vinte implantes 4,1 x 10mm foram divididos em dois grupos. Um ao qual foram conectados pilares de $5,5 \mathrm{~mm}$ parafusados com $35 \mathrm{Ncm}$, e outro ao qual foram conectados pilares octogonais e aplicado o mesmo torque. Coroas metalo-cerâmicas, com um protocolo 
laboratorial padronizado, foram fabricadas em ambos os grupos. As amostras do grupo cimentado foram divididas em dois e fixadas utilizando agentes de cimentação diferentes: ionômero de vidro e cimento fosfato de zinco. A manipulação dos cimentos foi realizada seguindo as instruções dos fabricantes, sendo as coroas assentadas com pressão digital, inicialmente, seguida da aplicação de uma carga constante de $10 \mathrm{~kg}$, durante dez minutos. As amostras foram armazenadas a $37^{\circ} \mathrm{C}$ em $100 \%$ de umidade, por 24 horas, e levadas a uma máquina de ensaio universal onde foi aplicada uma força de separação até a falha do cimento. Após esse procedimento, as coroas foram recimentadas. No grupo parafusado, as coroas foram fixadas ao pilar utilizando um parafuso oclusal de titânio de $4 \mathrm{~mm}$, com uma força de torque de $15 \mathrm{Ncm}$. Inspeção da discrepância marginal na interface coroa / implante foi realizada utilizando um aumento de 50 X, com um estereomicroscópio, em quatro áreas marcadas ao redor da circunferência do implante. Seus resultados mostraram que a menor discrepância marginal foi encontrada no grupo parafusado $(2,6 \mu \mathrm{m}$ antes da fundição do cilindro

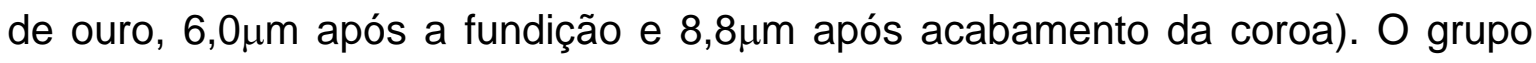
cimentado teve uma maior média de discrepância marginal, sendo de $32 \mu \mathrm{m}$ antes da fundição, $54 \mu \mathrm{m}$ após a fundição e de 57,4 $\mu \mathrm{m}$ e $67,4 \mu \mathrm{m}$ após a cimentação com ionômero de vidro e fosfato de zinco, respectivamente; sendo essas diferenças consideradas estatisticamente significantes entre os cimentos.

GUICHET et al. ${ }^{42}$, em 2000, compararam a integridade marginal e a tensão gerada durante o assentamento de restaurações retidas por implantes, cimentadas e parafusadas. A passividade de adaptação e as discrepâncias entre as próteses cimentadas e parafusadas foram avaliadas por um modelo fotoelástico de um arco mandibular parcialmente edêntulo, posterior, com três 
implantes do tipo rosqueados. Três implantes de 10mm (Nobel Biocare) foram fixados na área do primeiro e segundo pré-molar e do primeiro molar. Sobre estes, dez próteses foram fabricadas (cinco parafusadas e cinco cimentadas) em liga de ouro. Nas próteses parafusadas, foi utilizado um pilar cônico (3i) e sobre este um cilindro de ouro, o qual foi encerada e obtida a prótese. $O$ desenho de próteses cimentadas foi obtido utilizando pilares de perfil de emergência tipo postes (3i), os quais foram colocados sobre o modelo de trabalho e preparados seguindo as instruções do fabricante. Após polimento, foi realizado o enceramento e a fundição das próteses. As fundições parafusadas foram fixadas sobre os implantes com os valores de torque recomendado, e as cimentadas assentadas utilizando cimento de óxido de zinco e eugenol (Temp Bond, Kerr), sob uma carga de 4,5kg. Leituras da adaptação marginal foram realizadas antes e depois da cimentação e antes e depois do torque nas restaurações parafusadas. A passividade e a tensão gerada durante o assentamento foram avaliadas através de modelo fotoelástico. Concluíram que a desadaptação marginal das próteses, antes de ser parafusadas ou cimentadas, não foram estatisticamente diferentes entre os dois grupos (parafusadas $46,7 \mu \mathrm{m}$, e cimentadas 45,0 $\mu \mathrm{m}$ ). Após serem fixadas, o grupo de próteses parafusadas teve uma desadaptação marginal estatisticamente diferente que o grupo de próteses cimentadas após sua cimentação (parafusadas $16,5 \mu \mathrm{m}$, cimentadas $49,1 \mu \mathrm{m}$ ). Quando a geração da tensão foi avaliada, após a fixação ou cimentação das próteses, o desenho parafusado apresentou uma maior variabilidade na intensidade e localização da tensão que o desenho de próteses cimentadas.

TAYLOR; AGAR; VOGIATZI ${ }^{110}$, em 2000, afirmaram que a seleção de próteses cimentadas ou parafusadas envolve uma preferência pessoal, não 
existindo evidências de que um método de retenção seja superior a outro. Para os autores, as vantagens da restauração parafusada são limitadas à reutilização ou recuperação da restauração, enquanto que dentre as vantagens das restaurações cimentadas encontram-se: uma melhor estética, melhor oclusão, simplicidade de fabricação e redução dos custos dos componentes e da fabricação. Uma possível vantagem adicional da restauração cimentada é que tem potencial de ser colocada de forma passiva na boca, devido à ausência de um parafuso para puxar a desadaptação dos componentes com a força de aperto. Se uma pode ser feita para assentar passivamente em vários pilares, a introdução de cimento dentro do espaço entre as próteses e o pilar não introduzirá tensão no sistema. Esta potencial vantagem e as outras mencionadas fazem com que a restauração implanto cimentada tenha aumentado. Defensores da restauração cimentada afirmam, ainda, que a reutilização pode ser mantida se um cimento provisório é utilizado. Infelizmente, existem poucas evidências que demonstrem previsibilidade da reutilização de vários agentes cimentantes provisórios, quando são cimentados dois componentes metálicos. Isso significa, provavelmente, que um cimento que funciona como provisório, para restaurações cimentadas a dentes, será um agente cimentante definitivo para metal cimentado ao metal. Similarmente, cimentos utilizados para cimentação permanente podem ser inadequados quando cimentamos metal a metal.

Para determinar se os procedimentos laboratoriais de confecção das próteses suportadas sobre implantes alteram as superfícies de contato do pilar com a cabeça do implante, VIGOLO; MAJZOUB; CORDIO ${ }^{111}$, em 2000, avaliaram as alterações da interface implante/pilar, após a fundição com um metal nobre e aplicação de cerâmica em pilares tipo UCLA de ouro (3i). Utilizaram 30 
pilares (SGUCGI) que foram parafusados a análogos fixados em resina. Nos pilares, foram realizados enceramentos com dimensões de um incisivo central e fundido com uma liga áurea de alta fusão. Nestes, foram realizadas aplicações de cerâmica, seguindo as instruções recomendadas pelos fabricantes. Medidas foram realizadas antes, após a fundição e depois da aplicação de cerâmica, da profundidade e largura da porção interna do hexágono, diâmetro da base do pilar UCLA, e liberdade rotacional entre a extensão hexagonal do implante e a contraparte do pilar. Os resultados evidenciaram médias de 0,620mm, 0,621mm, e 0,620mm na profundidade do hexágono; 2,712mm, 2,710mm, e 2,711mm para a largura do hexágono interno; 4,408mm, 4,407mm, e 4,409mm para o diâmetro da base; 6,33min, 6,37min, 6,68min de liberdade rotacional (antes, após fundição e após aplicação da cerâmica respectivamente). Concluíram que a adaptação dos pilares UCLA de ouro (3i) não demonstraram alterações significantes das medidas originais, ou da liberdade rotacional na superfície da porção interna. Sugeriram a seleção adequada de componentes com baixa tolerância de usinagem, seleção adequada da liga metálica e a utilização de procedimentos clínicos e laboratoriais meticulosos para reduzir a desadaptação rotacional e aumentar a estabilidade do parafuso.

Em um trabalho sobre implantes e componentes, BINON ${ }^{13}$, em 2000, realizou uma classificação clara da extensa variedade de implantes disponíveis, baseado na forma de conexão da interface pilar/implante, na forma e na superfície do implante. Em relação à forma de união pilar/implante, afirmou que existem mais de 20 tipos diferentes de configurações desaa interface. Dessa forma, dois grandes tipos de conexões são conhecidos (externa e interna)s os quais são caracterizados pela presença ou ausência de uma configuração geométrica que 
se estende acima da superfície coronal do implante. A conexão coronal também pode ser caracterizada como uma união que permite movimento de deslize, onde existe um pequeno espaço entre as partes, e a conexão é passiva; ou como uma união por fricção, donde não existe espaço entre os componentes e as partes são forçadas para se adaptarem. Outro tipo de interface encontrado é a união de topo, que consiste em duas superfícies de ângulos retos; e a união angulada, onde as superfícies são anguladas externa ou internamente. A superfície de união também pode incorporar uma geometria que inclua uma configuração de resistência rotacional ou estabilização lateral. Dessa forma, a geometria pode ser octagonal, hexagonal, cone parafuso, cone hexagonal, cilíndrica hexagonal, spline, entre outros. Segundo o autor, conexões internas em que o parafuso recebe pouca carga e as superfícies do pilar estão em íntimo contato com as paredes do implante, para resistir a micromovimentos, resultam em uma interface mais estável. Para evitar falhas que provoquem instabilidade da prótese, procedimentos clínicos assim como parâmetros mecânicos, são críticos. Em relação aos componentes, uma ótima tolerância de adaptação, liberdade rotacional mínima, propriedades físicas melhoradas e uma aplicação de torque adequado, são determinantes na estabilidade da interface. Assim, mesmo na parte clinica, uma adequada distribuição, cargas dirigidas no longo eixo do implante, número, diâmetro e comprimento dos implantes, adaptação passiva da prótese e controle das cargas oclusais são igualmente importantes.

BROSCO $^{18}$, em 2001, avaliou através de microscopia eletrônica de varredura (MEV) o desajuste horizontal e a precisão de adaptação de pilares unitários em sistemas de implantes nacionais com hexágono externo. Os sistemas Titanium Fix (A.S Tecnology), Dentoflex (Dentoflex), Neodente 
(Neodente) e Master Screw (Conexão) foram avaliados e comparados com 0 Sistema Bränemark (Nobel Biocare) utilizado como grupo controle. Pilares do tipo Ceraone ou UCLA foram selecionados de acordo com a disponibilidade do sistema. Imagens obtidas através da MEV foram analisadas utilizando-se um programa computadorizado específico para medidas lineares das diferentes faces, áreas e ângulos de implantes e pilares. Seus resultados mostraram médias de largura do hexágono externo do implante e interno do pilar, e do desajuste horizontal da conexão implante/pilar de:

\begin{tabular}{cccc}
\hline Sistema & $\begin{array}{c}\text { Larg_hex_implant } \\
\mathbf{m m}\end{array}$ & $\begin{array}{c}\text { Larg_hex_pilar } \\
\mathbf{M m}\end{array}$ & $\begin{array}{c}\text { Desaj_horizont } \\
\text { Mm }\end{array}$ \\
\hline Dentoflex & 2,685 & 2,809 & 19,420 \\
Titanium Fix & 2,697 & 2,899 & 22,387 \\
Neodente & 2,807 & 2,843 & 19,603 \\
Master Screw & 2,699 & 2,827 & 16101 \\
Bränemark & 2,773 & 2,848 & 11,231 \\
\hline
\end{tabular}

Esses resultados dos sistemas de implantes e componentes nacionais, segundo o autor, mostram um bom nível de controle de qualidade, sendo que a indústria tem acompanhado a evolução tecnológica com produtos de qualidade internacional.

KRENNMAIR; SCHMIDINGER; WALDENBERGER ${ }^{63}$, em 2002, realizaram análises clínicas de 146 implantes Frialt-2 para substituição de elementos unitários. Cento e doze pacientes (67 mulheres e 45 homens) receberam um total de 84 implantes na maxila e 62 na mandíbula, localizados em todas as áreas da cavidade bucal, sendo os sítios mais freqüentes os dentes anteriores maxilares (38), assim como pré-molares e molares mandibulares (57). Noventa e três 
restaurações foram cimentadas utilizando-se um cimento provisório (Temp Bond / Kerr) e 53 parafusadas a pilares convencionais. A avaliação foi realizada por um período de 3 a 84 meses, com média de seguimento de 35,8 meses. Todos os pacientes incluídos no estudo foram avaliados a cada três meses no primeiro ano, e com intervalo de seis meses após o primeiro ano. Sobrevivência dos implantes assim como incidência e complicações protéticas foram registradas. Dois implantes $(1,4 \%)$ foram perdidos, um durante os primeiros três meses de aplicação da carga, e outro após seis anos, uma sobrevivência de 97,3\%. A complicação protética mais freqüente foi a necessidade de recimentação de nove coroas $(9,9 \%)$ e a substituição de quatro coroas $(2,8 \%)$ devido à fratura da cerâmica. Em nenhum caso foi encontrado afrouxamento do parafuso de fixação do pilar, porém em quatro casos $(3,5 \%)$ de parafusos horizontais foi encontrado afrouxamento do pilar. Com os resultados obtidos nesse estudo, os autores acreditam que a baixa percentagem de afrouxamento dos parafusos é devido à conexão hexagonal interna desse sistema, que se estende $5,5 \mathrm{~mm}$ dentro do implante, o que aumenta a resistência da conexão quando comparada com outros sistemas.

GIBBARD; ZARB ${ }^{35}$, no mesmo ano, apresentaram a continuação do estudo de avaliação longitudinal realizado por ARBER, ZARB, em 1996, em implantes unitários após cinco anos de função. A amostra do estudo original consistiu de 42 pacientes tratados com 49 implantes unitários do sistema Bränemark. Nesse estudo havia 24 pacientes com 30 implantes dos originalmente tratados e que foram avaliados clinica e radiograficamente; a estética também foi avaliada por assistente dental, estudantes e dentistas. Todos os 30 implantes avaliados permaneceram estáveis, sendo que nenhum deles foi associado à 
fístula ou mobilidade. Afrouxamento do parafuso de ouro foi encontrado em 13\% das coroas, mas em nenhum dos parafusos dos pilares foi observado afrouxamento. Radiograficamente, foi observada uma média de perda óssea anual de 0,2mm e os pacientes avaliaram as próteses como satisfatórias.

Em uma análise clínica de implantes ITI colocados e restaurados por periodontistas e protesistas, LEVINE et al. ${ }^{71}$, em 2002, avaliaram a sobrevivência de 675 restaurações unitárias no setor posterior, suportadas por implantes, e compararam restaurações cimentadas e parafusadas. Quatrocentos e setenta e um pacientes (292 mulheres e 179 homens) receberam os implantes colocados na região posterior da boca, sendo 370 no molar superior, 126 pré-molar inferior, 108 pré-molar superior e 71 molar superior, dos quais 615 implantes foram de 4,1mm de diâmetro e 60 de 4,8mm. Em 600 dos implantes integrados foram realizadas restaurações cimentadas, e em 71 parafusadas. O tempo de acompanhamento após a carga dos implantes, foi de 1 a 78 meses, média de 18 meses. Durante o período de investigação, os resultados mostraram $99,1 \%$ de sobrevivência com 98,4\% na mandíbula e 100\% na maxila. As complicações com as coroas cimentadas incluíram $0,3 \%$ de afrouxamento do parafuso (dois pacientes); 0,5\% das coroas tiveram que ser substituídas devido à fratura do pilar (três pacientes); 0,6\% recimentadas devido a afrouxamento por dissolução do cimento; duas coroas tiveram que ser refeitas por fratura da cerâmica. As complicações associadas às coroas parafusadas incluíram $16,9 \%$ de afrouxamento dos parafusos de retenção das coroas (12 pacientes); 1,4\% dos parafusos afrouxou várias vezes (um paciente); em um paciente com uma coroa parafusada utilizando conexão direta do implante, o parafuso afrouxou $(1,4 \%)$. Em todos os pacientes nos quais foram instaladas coroas parafusadas ao pilar, um 
retorque de $20 \mathrm{Ncm}$ foi aplicado, e na conexão parafusada ao implante, $35 \mathrm{Ncm}$. Concluíram que os mínimos problemas restauradores das coroas cimentadas $(98,2 \%)$ e parafusadas $(80,3 \%)$ sugerem que os implantes ITI podem ser utilizados satisfatoriamente para substituir restaurações unitárias do setor posterior da boca.

Analisando as forças oclusais desenvolvidas sobre diferentes materiais utilizados na superfície oclusal de próteses sobre implantes, BASSIT; LINDSTROM; RANGERT ${ }^{8}$, em 2002, investigaram se as forças transmitidas aos implantes, in vivo, são influenciadas pela resina acrílica ou pela cerâmica como material de revestimento. Cinco pacientes, previamente tratados com implantes osseointegrados na região posterior da boca, foram utilizados no estudo, sendo a região do pré-molar selecionada para a realização dos testes. Duas coroas foram fabricadas para cada paciente; uma com resina acrílica (Meliodent, Heraus Kulzer) sobre um coping plástico convencional (Bränemark System), e a outra cerâmica (Vintage, Shofu) sobre uma liga de ouro cerâmico, fundido sobre um cilindro de ouro standard de 4mm (Bränemark System). As coroas unitárias foram unidas a pilares standard de 5,5mm, aos quais estavam unidos três strain gauges. Para assegurar que as forças oclusais fossem transmitidas através das próteses, estas foram ajustadas em supra-oclusão, de forma a estabelecer sempre o primeiro contato durante a mastigação e/ou oclusão sobre a prótese. Inicialmente, os pacientes foram orientados a realizar um movimento de mordida rápido, e depois vários movimentos rápidos de mordida. As forças aplicadas foram registradas, bem como a tensão e a correspondente força axial foi calculada. Este protocolo também foi aplicado a um modelo in vitro, no qual o implante foi instalado sobre um aço e o impacto da mandíbula foi gerado por um peso de $164 \mathrm{~g}$ 
desde uma altura determinada. O pico de força máximo foi registrado. As medidas in vivo mostraram uma grande variação no pico de força aplicada, não se encontrando diferenças estatisticamente significantes entre os diferentes materiais testados. O coeficiente do pico de força variou entre $20 \%$ e $130 \%$, com pico mínimo de $154 \mathrm{~N}$ e máximo de $2055 \mathrm{~N}$ para a resina acrílica, e de $63 \mathrm{~N}$ e 1280N para a cerâmica, respectivamente, entre os diferentes pacientes. No modelo in vitro, os picos de forças foram maiores, sendo encontrado na cerâmica um pico maior de força que na resina. O coeficiente de variação no pico de força foi de $10 \%$ a $35 \%$, tanto na resina quanto na cerâmica, ou seja, picos de forças mínimos de $110 \mathrm{~N}$ e máximo de $530 \mathrm{~N}$ para a resina e de $310 \mathrm{~N}$ e $3.668 \mathrm{~N}$ para a cerâmica respectivamente. Os autores concluíram que os diferentes materiais oclusais não levam à geração de forças diferentes sobre os implantes nos pacientes e que o grau de resiliência entre a cerâmica e a resina foi observado somente no estudo in vitro, onde a força é gerada por um choque e o implante é rigidamente ancorado.

Seguindo o princípio observado por BINON de que as discrepâncias entre os hexágonos dos pilares e dos implantes, e que a liberdade rotacional do pilar sobre o implante deve ser menor de cinco graus para se obter uma união estável; LANG; WANG; MAY ${ }^{66}$, em 2002, examinaram a orientação do hexágono do pilar no hexágono do implante depois do aperto do parafuso, em diferentes sistemas de pilares. Examinaram, também, a influência do dispositivo de contratorque na configuração hexagonal do pilar/implante após o aperto do parafuso. Na sua metodologia, utilizaram implantes (Nobel Biocare) de plataforma regular $(3,75 \mathrm{x}$ 10,0mm) e implantes de largo diâmetro $(5,0 \times 10,0 \mathrm{~mm})$. Os pilares ceraone, esteticone, procera e ouradapt foram também estudados. Cada implante foi fixado 
em um dispositivo e depois aplicado o torque recomendado para cada sistema, utilizando-se um Controlador eletrônico de torque (Nobel Biocare). Em cinco amostras de cada grupo no aperto foi utilizado um dispositivo de contratorque e nas outras cinco não. Depois do aperto, as amostras foram removidas e incluídas em uma resina (EKACT / Kulzer). Um corte foi realizado em direção horizontal ao nível do hexágono. A orientação do hexágono interno do pilar no hexágono externo do implante foi avaliada, assim como o grau e a direção da rotação do hexágono do pilar no hexágono do implante. Os resultados mostraram uma média do grau de rotação para os quatro sistemas testados, com e sem o uso do contratorque menor de 3,53 graus. Quando o contratorque foi utilizado, todos os sistemas tiveram uma média absoluta de rotação menor que 1,50 grau, depois do aperto do parafuso do pilar. Concluíram que a orientação hexágono-hexágono medida como a liberdade rotacional, nos sistemas testados, foi abaixo de cinco graus o que sugere uma ótima estabilidade da união parafusada e que o uso do contratorque tem pouca influência na orientação do hexágono do pilar ao redor do hexágono do implante.

TAVAREZ $^{108}$, em 2003, realizou um trabalho com o objetivo de estudar as alterações na interface implante/pilar em sistemas de conexão externa e interna através das medidas da desadaptação, e a condição de torque e destorque dos parafusos de fixação quando submetidos a ensaios de fadiga. Em cinco grupos que foram estudados: grupo I implante HE e pilar UCLA, com restaurações cimentadas; grupo II implante de $\mathrm{HI}$ e pilar pré-fabricado, com restauração cimentada; grupo III implante HI e pilar pré-fabricado, com restauração cimentada; grupo IV implante de HE e pilar UCLA, com restauração parafusada; e grupo V implante HE pilar ceraone, com restauração cimentada. Os corpos de prova foram 
submetidos a ensaios de fadiga até 500.000 ciclos utilizando-se uma máquina de ensaio MTS 810. Testes de torque e destorque nos parafusos de fixação, e análise da desadaptação da interface implante /pilar antes e depois da aplicação das cargas foram realizados. Foi possível observar que: 1- houve diferenças no diâmetroda base de assentamento dos implantes e pilar entre 0,03mm a 0,75mm; e no diâmetro do hexágono/ octágono entre implantes e pilares entre 0,01 e 0,05mm, sendo que no grupo que utilizou HI não foram encontradas diferenças; 2o comprimento dos parafusos variou entre $5,95 \mathrm{~mm}$ e $8,83 \mathrm{~mm}$, o comprimento das roscas variou entre 4,52 e 5,72mm, enquanto que o diâmetro entre 1,79 e 1,997; 3- após o ensaio de fadiga, houve um aumento do HE que utilizaram pilares UCLA e no grupo de HI; sendo menor desadaptação observada no grupo de HE que utilizou pilares Ceraone $(3,81 \mu \mathrm{m})$; 4- houve redução estatisticamente significante da condição de torque dos grupos estudados após o ensaio de fadiga e 5- houve uma forte correlação entre a aplicação das cargas cíclicas e a diminuição da condição de torque; enquanto que nas demais variáveis não existiu esse tipo de correlação.

\section{2- Ligas, parafusos e condições de toque.}

MYER; CRUICKSHANKS-BOY ${ }^{82}$, em 1982, relatam as importantes características da liga AgPd disponível comercialmente. Embora essa liga possua alta dureza, é possível conseguir uma adaptação marginal aceitável com satisfatória habilidade técnica. Existe, também, uma boa compatibilidade destas ligas com a porcelana, interessando em particular à estética e longevidade das próteses. O molde do caso clínico, menor extensão desse molde e a temperatura de fundição da liga influenciam na adaptação da mesma, não apresentando efeito 
rugoso na superfície e a correta proporção do conjunto (líquido especial/ água) usado para misturar com o pó, sendo fundamental para o grau de adaptação. Dentro das limitações desse estudo, uma liga de AgPd pode ser uma alternativa aceitável para substituir ligas de ouro para restaurações dentais. Esse estudo variou o grau de adaptação porque mudou a proporção pó/líquido preconizada pelo fabricante e temperatura de fundição, ocorrendo a variação na adaptação marginal. Os autores observaram que a discrepância marginal é significantemente influenciada pela temperatura da matriz $(p<0,01)$, mas não pela temperatura de fundição ( $p>0,05)$. A superfície apresenta uma rugosidade excelente para adaptação de $1.0 \mu \mathrm{m}$. Os autores concluíram que paládio e prata são uma alternativa às ligas para uso odontológico.

Em 1984, o National Institute of Dental Research ${ }^{27}$, realizou um workshop pela anfitriã American Dental Association em julho. Esse workshop examinou o uso de metais para uso odontológico frente às seguintes perspectivas: potencial de toxicidade, potencial alergênico, potencial carcinogênico, experiência clínica de uso dos metais e uma condição alternativa de desenvolvimento desses materiais para o uso de procedimentos restauradores. Com relação ao níquel e cromo, relataram:

Níquel: é a liga mais comumente usada em próteses, tendo também na sua composição cromo ou cobalto, sendo a maior quantidade de Ni (81\%). O níquel pode ser implicado como um material tóxico em grandes quantidades, porém não para os dentes. No ar, a poeira pode conter níquel que, quando inalado, leva à indução carcinogênica. Podemos estar em contato com o níquel em jóias, botões, zíperes e fecho de roupa, induzindo assim à sensibilidade. Uma prevalência foi estimada, e $10 \%$ em mulheres e menos de $1 \%$ em homem, podem apresentar 
reações alérgicas do níquel com as membranas da mucosa. É, então, recomendado fazer testes para verificar a sensibilidade ao níquel quando se suspeita que o paciente possa ter alguma reação alérgica.

Cromo: pode produzir dermatite crônica, já observada e relatada em indivíduos com sensibilidade. A sensibilidade é resultado dos contatos com o sal cromate resultando uma corrosão de tal liga. Relatos de alergia com o cromo são raros.

ANUSAVICE' ${ }^{2}$, em 1985, comparou a evolução positiva e negativa existente em metais nobres. As ligas nobres são basicamente em ouro e paládio, sendo os principais metais nobres. Os metais nobres (ouro, o paládio e platina) não oxidam e são resistentes ao manchamento intra-oral e à corrosão. A composição do paládio-prata nessas ligas é de 53 a 61\% de paládio e 28 a 40\% de prata. Essa liga alternativa, em relação às ligas à base de ouro, tem boa compatibilidade com as porcelanas. O autor concluiu que a seleção da liga ideal deveria ser responsabilidade dos dentistas, para confecção das infra-estruturas das próteses, não devendo ser essa escolha delegada ao técnico do laboratório.

BARAN $^{7}$, em 1985, num estudo onde mostra uma seleção criteriosa do metal para base de coroas de porcelana, relata que o cromo é a base das ligas que podem ser NiCr e CoCr, onde não ocorre manchamento desse metal, pois é influenciado pela boa resistência à corrosão. Em suas características, apresenta alto módulo de elasticidade em relação aos metais nobres, resistência à flexão superior e custo menor. Todas as ligas que possuem o cromo em sua constituição favorecem as propriedades físicas e químicas, sendo utilizada para união do metal com a porcelana. Para a utilização dessas ligas na fabricação de próteses, o indivíduo deveria, primeiro, estar ciente da modificação das técnicas de fundição 
para reproduzir uma fiel adaptação. Diferenças mecânicas são importantes, como o módulo de elasticidade e a dureza, podendo existir variações dessas propriedades entre as ligas de NiCr e CoCr.

RASMUSSEN $^{90}$, em 1987, fez considerações sobre a escolha da liga para confecção de prótese sobre implantes. Os fatores biocompatibilidade, resistência e custo foram colocados em evidência. Outros itens lembrados foram a resistência à corrosão dos metais nobres, sua aceitabilidade pelos tecidos e o tempo que atesta a validade do seu uso. Colocou o paládio-prata como liga nobre para substituição do ouro e ressaltou a importância da utilização de ligas com alta porcentagem de metais nobres. Dentro do contexto, fez considerações e observações sobre o módulo de elasticidade da liga a ser utilizada com os implantes, salientando que a maior exigência está localizada nas regiões de maior extensão não sustentadas por pilares. A liga mencionada como exemplo foi a Optin ( J. M. Ney Co., Conn., USA). Relatou, ainda, que o módulo de elasticidade da liga de paládio prata é $13,6 \times 10^{6} \mathrm{MPa}$ e do titânio puro é $15 \times 10^{6} \mathrm{MPa}$. Então o autor concluiu que a utilização de ligas que fornece uma distribuição de cargas adequada, deverá ser aquela com o valor do módulo de elasticidade próximo ao do titânio.

GOODACRE $^{39}$, em 1989, preconizou a terminologia correta para aplicação e fundição dos metais para coroas metalocerâmicas. A liga é chamada de paládio-prata, cuja composição é de $50 \%$ para $60 \%$ de paládio e $30 \%$ para 40\% de prata. Prata-paládio são ligas à base de prata e não são indicadas para o uso em restaurações metalo-cerâmicas, pois em sua fórmula contém de 60 a 70\% de prata e 30\% de paládio (reverso da porcentagem de paládio-prata). A primeira liga de paládio-prata (Cameo- leite, J.F. Jetenko, L. Co. Inc), foi introduzido em 1973, 
sendo patenteada por Willians Dental Co. inc.) e lançada 1 ano mais tarde, em 1974. Com a evolução das técnicas de fundição e melhora da adaptação marginal, o paládio-prata passou a ser uma liga aceitável para substituir a liga de ouro. Existem alguns relatos indicando problemas com a fundição e porosidade dessas ligas. Essa liga não superaquece e derrete ocorrendo uma alta densidade do metal na fundição, podendo ser comparada com a adaptação de outro metal nobre para cerâmica. A descoloração da porcelana, que poderia ocorrer com o uso da liga de paládio-prata, pode ser reduzida ou eliminada usando certamente uma outra marca de porcelana. Propriedades físicas, características na manipulação e compatibilidade com a porcelana, quando do uso da liga de paládio-prata, podem ser os aspectos mais importantes para serem comparados ou podendo ser superiores a outros metais nobres para aplicação de cerâmica.

\section{O COUNCIL ON DENTAL MATERIALS, INSTRUMENTS AND} EQUIPMENT ${ }^{28}$, em 1989, relatou a restrição do uso de metais não nobres para confecção de próteses, já que essas ligas apresentavam menor quantidade de metais nobres (entre 75 a 78\%), sofrendo manchamento ou corrosão na boca. Como o custo dessas ligas alternativas é mais baixo, a freqüência de uso pelos dentistas é maior, levando assim ao avanço da metalurgia e ao maior conhecimento desses materiais. Com a especificação original $n^{\circ} 5$ da A.D.A, uma proliferação de ligas e sistemas têm provado ser substitutos viáveis das ligas com alto conteúdo em ouro.

Para verificar o comportamento da adaptação marginal de coroas totais sobre troquéis de dentes naturais, quando fundidas com diferentes ligas, TJAN et al. ${ }^{109}$, em 1991, utilizaram seis diferentes ligas. A partir de um mesmo corpo de prova obtiveram vários troquéis e seus respectivos enceramentos com forma de 
coroa total. Os procedimentos de inclusão e de fundição foram padronizados, respeitando os cuidados preconizados para cada grupo de liga utilizada. Após a limpeza e o acabamento, as coroas foram cimentadas sobre seus troquéis e submetidas à observação ao microscópio. O grupo das coroas fundidas em ouro tipo III foi considerado grupo controle ou base de comparação. Os resultados médios encontrados como interface troquel/coroa foram: ouro do tipo III- $8 \mu \mathrm{m}$; liga com baixo conteúdo de ouro e paládio como base- $23 \mu \mathrm{m}$; liga Spirit II (base paládio)- $45 \mu \mathrm{m}$; cobre/alumínio- $60 \mu \mathrm{m}$; níquel/cromo/molibidênio- $86 \mu \mathrm{m}$; prata/paládio- $17 \mu \mathrm{m}$. Os autores concluíram apresenta que o ouro tipo III apresenta resultados em adaptação significantemente superior a qualquer das outras ligas; as ligas à base prata/paládio permitem adaptação melhor do que os outros tipos de ligas; as ligas à base de níquel/cromo/molibidênio apresentaram os resultados menos satisfatórios.

JǾRNEUS; JEMT; CARLSSON ${ }^{56}$, em 1992, examinaram 4 tipos de pilar de conexão (3 graduações do titânio ASTM e uma liga de ouro) que receberam valores de torque entre 20 e $35 \mathrm{Ncm}$. Os valores de torque considerados ótimos para cada modelo de pilar de conexão foram utilizados. A estabilidade de cada articulação foi, então, avaliada nesse estudo in vitro antes e após função horizontal simulada. Apenas o pilar de conexão fabricado com liga de ouro manteve a estabilidade da articulação sob uma carga maior que $50 \mathrm{Ncm}$. Entretanto, os autores estabeleceram que sob cargas típicas, a maior parte dos pilares de conexão manteria a estabilidade. Os fabricantes de implantes reconhecem que o afrouxamento do pilar de conexão é um problema significativo e têm tentado solucionar essa dificuldade por meio de características inovadoras que impedem movimentos rotacionais. 
A significância do planejamento do parafuso e a necessidade de se aplicar um torque correto, mesmo sendo discutível o desalinhamento de um cilindro de ouro e seu respectivo pilar de conexão, levaram PATTERSON; JOHNS ${ }^{85}$, em 1992, a avaliarem a fadiga dos parafusos utilizados em implantes. Para os autores, a fadiga do metal é, talvez, a causa mais comum de falha estrutural. Uma pré-carga pode ser aplicada ao parafuso quando o torque é máximo. Dessa forma, a união que mantém os componentes pode ser perdida. O fato de não se conseguir uma adaptação passiva faz com que não haja uma perfeita união entre os componentes durante a pré-carga, o que pode influenciar uma fadiga reduzida a semanas. Se a adaptação é pobre, durante a pré-carga, pode haver um deslizamento entre as estruturas e o contato poderá ser total. Segundo Junker e Wallace, junções rosqueáveis sobre cargas excêntricas com uma maior précarga, poderão aumentar o tempo de fadiga do parafuso. Para os autores, uma pequena alteração pode ser encontrada nos trabalhos protéticos, ou pode existir algum erro técnico na impressão ou na fabricação das estruturas. Para essa compensação é necessário um apertamento máximo do parafuso e é indicado alcançar um torque apropriado para cada parafuso em particular.

TAN et al. ${ }^{105}$, em 1993, avaliaram a distorção tridimensional em infraestruturas confeccionadas em liga de paládio-prata fundida em monobloco sobre um modelo com cinco implantes. Compararam duas formas de infra-estruturas: "L" e "U" (recomendadas pelo grupo de Toronto). Consideraram o deslocamento dos cilindros de ouro das amostras em relação aos intermediários do modelo mestre quanto aos deslocamentos de translação e de rotação. Empregaram medidas de coordenadas com o auxílio de uma máquina de medidas de coordenadas acoplada ao programa de microcomputador AVAIL (Advanced 
Validator Interfacing Language), o qual armazenava e calculava os dados geométricos. Não encontraram diferenças entre as formas das infra-estruturas. A localização dos cilindros no arco foi associada a deslocamentos de translação e rotação com direção e magnitude específicas. Pequenas distorções rotacionais promoveram fendas verticais amplas quando realizaram o teste de adaptação inicial com apertamento de um parafuso. Entretanto, tais distorções podem ser camufladas quando o torque de apertamento é dado nos parafusos, fazendo a infra-estrutura parecer adaptada, provocando tensões externas de pré-carga no sistema.

No mesmo ano, MARIO; LA CROIX ${ }^{74}$ elaboraram um estudo comparativo, entre uma liga de ouro convencional e uma liga semi-nobre de prata paládio, com 7\% de ouro na sua composição. Após todos os testes e critérios préestabelecidos, foi observado que no emprego desta liga, se comportou de modo seguro no que se tange às suas propriedades físico-químicas e biológicas, quando no uso odontológico. Os autores concluíram, que a liga alternativa seminobre de prata-paládio, comparada com a liga de ouro convencional, desde que empregada observando seus critérios clínico-protéticos, atende de modo satisfatórios as exigências. Assim sendo, acreditamos que esta pesquisa tenha contribuído de maneira relevante para o conhecimento profundo de novos ensaios no campo integrado Metalurgia e Odontologia.

SUTTER; WEBER; SORENSEN ${ }^{104}$, em 1993, apresentaram o desenho e engenharia do Octa-abutment o qual é um pilar restaurador do sistema ITI (Bonefit). Relataram também os resultados de testes de vários parâmetros críticos para a estabilidade longitudinal do complexo implante/supraestrutura com este pilar. O desenho do mesmo se acopla na porção coronária do implante e é 
composto de um cone de $8^{\circ} \mathrm{com}$ um parafuso de $2 \mathrm{~mm}$ de diâmetro. A porção coronal do pilar consiste de uma cabeça octagonal com uma altura total de $1,5 \mathrm{~mm}$ acima do ombro do implante, sobre o qual é acoplado um cilindro de ouro que tem um encaixe preciso até o ombro do implante. Utiliza um parafuso de retenção de titânio oclusal de $2 \mathrm{~mm}$ de diâmetro, com cabeça de 2,5mm. Dois desenhos diferentes são disponíveis para os cilindro de ouro; um para restaurações unitárias com desenho anti-rotacional e outro para múltiplas restaurações. Resultados dos testes mecânicos com os pilares relatados pelos autores garantem que o desenho cônico interno proporciona adaptação friccional, o que elimina o risco de rotação ou afrouxamento das partes. Os resultados dos testes da aplicação de força de rotação até a falha proporcionaram forças maiores de 400Ncm. Quando foram comparados testes de torque de aperto contra torque de afrouxamento os resultados revelaram que o torque de afrouxamento foi entre 10 e $15 \%$ superior ao torque de aperto, o que segundo os autores resulta em um aumento de $20 \%$ na resistência ao afrouxamento para um nível de torque determinado. Em testes de carga dinâmica, foi relatado que após dois milhões de ciclos, o torque de afrouxamento não diminuiu quando comparado com o torque de aperto antes da carga; por estes resultados, os autores acreditam que a estabilidade mecânica deste sistema favorece biologicamente, sendo obtidas restaurações estéticas com procedimentos técnicos simples, o que fornece garantia de sucesso à restauração.

A significância de apertar parafusos de pilar de conexão e cilindros de ouro em implantes osseointegrados de pilar de conexão e cilindros de ouro em implantes osseointegrados com torque correto foi demonstrado em 1994 por BURGUETE et al. ${ }^{19}$, em artigo sobre a importância do apertamento dos pilares de 
conexão a implantes osseointegrados, bem como sobre os métodos de aplicação de torque. Os métodos disponíveis até o momento para o apertamento de pilares de conexão (controle de torque, controle de ângulo e controle de torque/ângulo) foram descritos e os autores concluíram que é necessário o desenvolvimento do dispositivo para aplicação do torque com base em métodos de controle do torque/ângulo.

Em 1994, GOHEEN et al. ${ }^{37}$, avaliaram a capacidade de práticos experimentados no uso de componentes de implantes Bränemark para dar o torque desejado usando chaves de fenda manuais. Foram examinadas também a força do torque e a varibilidade de aparelhos mecânicos. Para clínicos que utilizaram chaves de fenda manuais, os valores variaram de $0,7 \mathrm{Ncm}$ a $18,1 \mathrm{Ncm}$, $1,4 \mathrm{Ncm}$ a $33,7 \mathrm{Ncm}$ e $8,2 \mathrm{Ncm}$ a $36,2 \mathrm{Ncm}$ para os torques de $10 \mathrm{Ncm}, 20 \mathrm{Ncm}$ e 32Ncm, respectivamente Os aparelhos mecânicos operados manualmente produziram valores de torque dentro das tolerâncias especificadas pelos fabricantes em todos os níveis. Foi observada variação significativa dos valores propostos pelos fabricantes como uma função de velocidade de apertamento com o aparelho de torque eletrônico em todos os níveis. Os dados observados indicaram que existe uma grande variação na habilidade dos clínicos para alcançar um torque adequado aplicado aos componentes do implante. Os aparelhos de torque calibrados são imprescindíveis se os procedimentos de torque apropriados forem realizados.

Em um estudo sobre os aspectos biomecânicos dos parafusos, BINON ${ }^{12}$, em 1994, afirmou que deficiente aperto dos parafusos, próteses inadequadas, pouca adaptação dos componentes, carga excessiva, falta de assentamento dos parafusos, desenho inadequado do parafuso e a elasticidade do osso contribuem 
para a instabilidade dos parafusos. Segundo o autor, para se obter uma união estável, valores de torque recomendados nos vários tipos de componentes devem ser seguidos, sendo que para os mesmos devem ser utilizados dispositivos mecânicos de torque que ofereçam maior consistência nas diferentes áreas da cavidade oral. Assim mesmo, afirmou que, a adaptação passiva dos componentes se torna essencial para evitar micromovimentos e instabilidade do parafuso. Um outro fator comentado por ele é a condição de carga excessiva, devido ao número e localização dos implantes, assim como o desenho de um esquema oclusal deva ser adequadamente observado para evitar sobrecargas que levem à instabilidade dos parafusos. Da mesma forma, afirmou que características como diâmetro, comprimento, tipo de roscas, e conexidades dos parafusos nos diferentes sistemas podem predispor fraturas; sendo que a rugosidade excessiva, usinagem ruim, liga com resistência insuficiente e elongação afetam as características desses parafusos. Assim como a qualidade óssea da área receptora do implante tem importância na estabilidade do parafuso, sendo que na maxila, devido a maior quantidade de osso esponjoso, existe uma maior deformação quando forças compressivas são aplicadas. Cargas oclusais na maxila resultam em maior tensão na união osso implante e na união do implante com a prótese, tendo-se como resultado uma maior instabilidade do parafuso. Da mesma forma, afirmou que falhas dos parafusos são mecanismos de proteção dos implantes; sendo que na configuração padrão do sistema Bränemark, a fratura plástica dos parafusos de ouro ocorrem em $16,5 \mathrm{Ncm}$ e no caso dos parafusos do pilar tipo UCLA em elementos isolados, ocorre em $40 \mathrm{Ncm}$; o que permite que o torque seja aumentado em aproximadamente $80 \%$. 
No mesmo ano, SHUTTER et al. ${ }^{103}$ afirmou que o parafuso deve ser considerado como uma parte importante do desenho da supra-estrutura dos implantes e não como um elemento isolado, acreditando que os problemas relacionados a este envolvem a qualidade e desenho da conexão entre o implante e o pilar. Segundo ele a utilização de um parafuso cônico de oito graus em conjunção com $2 \mathrm{~mm}$ de roscas elimina a rotação do pilar através de uma adaptação da fricção mecânica; nesta conexão cônica micromovimentos nas roscas são eliminados não existindo a transmissão de uma carga funcional nas roscas, já que a precisão da conexão cônica absorve as vibrações. Afirma que entre o torque de aperto e o torque de afrouxamento está a diferença principal. Segundo ele no desenho do parafuso tradicional o torque de afrouxamento é $10 \%$ menor que o torque de aperto enquanto que no parafuso cônico o torque de afrouxamento é 10 a $20 \%$ maior que o torque de aperto. Segundo ele quando estes parafusos foram testados em uma situação de carga dinâmica, onde foram apertados com $50 \mathrm{Ncm}$ e com uma carga de $200 \mathrm{~N}$, o torque de afrouxamento depois de 500.000 ciclos foi de $51 \mathrm{Ncm}$ e depois de 2.000 .000 de ciclos foi de $56 \mathrm{Ncm}$, o que significa a inexistência de afrouxamento. No caso de parafusos com desenhos convencionais o torque de afrouxamento foi para $36 \mathrm{Ncm}$ depois de 500.000 ciclos e $27 \mathrm{Ncm}$ depois de 2.000 .000 ciclos, sendo estes apertados a $50 \mathrm{Ncm}$, o que sugere micromovimentos e tendência para afrouxamento do parafuso. Um outro aspecto discutido por SHUTTER é sobre o parafuso oclusal; quando este é de titânio de $2 \mathrm{~mm}$ de diâmetro pode ser conseguido um maior momento de afrouxamento que com o parafuso de ouro de diâmetro menor, sendo que o mesmo princípio da conexão cônica aplicada no parafuso do pilar. 
Em 1995, KANO et al. ${ }^{58}$, analisaram a desadaptação do cilindro de ouro do sistema Nobelpharma, comparando com peças similares fundidas a partir de matrizes calcináveis da empresa Implant Inovatins Inc. (3i) usando diferentes tipos de ligas metálicas: Porson-4, Palliag-M e Durabond. Após a confecção de 5 amostras para cada grupo realizaram as medidas em um projetor de perfil com aumento de 30 vezes. Obtiveram como resultados, em ordem crescente de

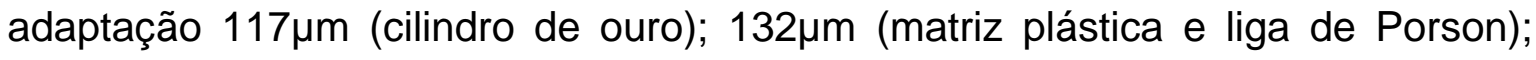

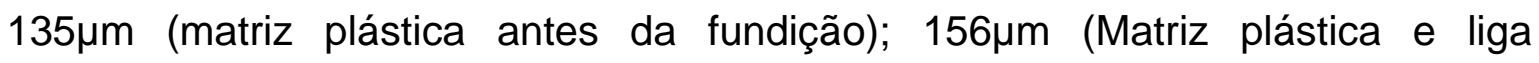

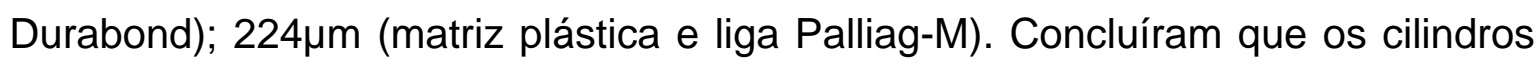
de ouro eqüivalem às matrizes de plástico e as peças fundidas com Porson.

Em 1995, ISA; HOBKIRK ${ }^{47}$, avaliaram, in vitro os efeitos causados pelo aperto dos parafusos de ouro em uma prótese com 5 elementos, assim como os efeitos de se parafusar próteses com diferentes graus de desajustes. Os resultados mostraram que o aperto de cada parafuso de ouro produziu altas forças compressivas, mesmo quando as próteses não eram igualmente distribuídas nem consistentes. Quando diferentes graus de desajuste foram criados na interface intermediário/cilindro de ouro, observou-se que forças de tensão eram produzidas mesmo em desajustes tão pequenos quanto a $10 \mu \mathrm{m}$.

JAARDA; RAZZOOG; GRATTON ${ }^{49}$, em 1995, examinaram os parâmetros geométricos de maior impacto na relação torque / pré-carga, de cinco parafusos de retenção protéticos intercambiáveis. Através de microscopia eletrônica de varredura (MEV), parafusos testes de fenda de dois tipos de ligas foram selecionados de três fabricantes sobre o fato de estes serem intercambiáveis com o parafuso de retenção de ouro Nobelpharma; sendo que estes foram utilizados como grupo controle com o qual os parafusos testes foram comparados. Os 
parafusos de ouro 3i, Impla-Med, e Nobelpharma; e os parafusos de titânio 3i, e Implant Support Systems foram testados. Cinco parafusos de cada tipo e oito parâmetros foram medidos: (A) diâmetro da cabeça do parafuso; (B) comprimento do parafuso; (C) distância entre o pico das roscas; (D) diâmetro principal; (E) diâmetro do pescoço do parafuso; (F) comprimento do pescoço; (G) largura da crista. Os resultados mostraram diferenças estatisticamente significantes em cinco parâmetros, sendo que somente nos parâmetros C e G não apareceram diferenças. Para o parâmetro A o diâmetro da cabeça do parafuso de ouro 3i, e do parafuso de titânio Implant Support Systems, foram maiores que os parafusos de ouro Nobelpharma. Para o parâmetro B, os comprimentos dos parafusos de ouro e de titânio 3i foram menores do que os parafusos do grupo controle; entretanto os parafusos de ouro da Impla-Med e de titânio da Implant Suport System foram maiores. No parâmetro D os parafusos de ouro da Impla-Med tiveram um diâmetro significativamente menor que os parafusos controles. No parâmetro E, os parafusos de ouro Impla-Med e de titânio 3i foram significativamente menores. No parâmetro F, os parafusos de ouro e de titânio 3i tiveram pescoços maiores, enquanto que os parafusos de ouro Implat Support System foram menores. Dessa forma, os autores concluíram que as diferenças encontradas entre os parafusos podem introduzir variáveis desconhecidas no tratamento dos pacientes, e que na base dos princípios de engenharia em relação a desenho dos parafusos, e a relação torque pré-carga, pode ser que as recomendações de torque de aperto para os parafusos Nobelpharma não sejam aceitas como certas para todos os desenhos de parafusos.

SAKAGUCHI; BORGERSEN ${ }^{94}$, em 1995, utilizaram um método de elementos finitos para avaliar o mecanismo de transferência de carga entre os 
componentes protéticos. Criaram modelos baseados na marca 3i representando um pilar reto com seu parafuso, um cilindro de ouro de 3,0mm, e um parafuso de fixação de ouro de 3,0mm, fixados a um implante $3,75 \mathrm{~mm}$ de diâmetro. Nestes componentes foi avaliada a distribuição da tensão nos parafusos depois da aplicação de um torque de $10 \mathrm{Ncm}$ ao parafuso de fixação de ouro e de $20 \mathrm{Ncm}$ ao parafuso de titânio do pilar e sua possível predisposição a falha. Seus resultados mostraram que a elongação do parafuso é obtida enquanto se permite a recuperação elástica do parafuso para produzir uma força de ajuste nos elementos de fixação. A pré-carga no parafuso do pilar resultou em contato na interface implante/pilar; nas primeiras quatro roscas de parafusos do pilar e na interface parafuso de pilar/pilar. As forças mais altas foram geradas na interface implante/pilar $(120,6 \mathrm{~N})$. As forças no pilar na interface parafuso/pilar foram similares em magnitude aquelas roscas dos parafusos $(75 \mathrm{~N})$. As forças totais de contato na interface pilar/implante foram de $188,3 \mathrm{~N}$ e $187,2 \mathrm{~N}$ no pilar na interface pilar/parafuso em direção axial. As maiores tensões foram verificadas em direção da segunda e terceira roscas do parafuso do pilar (10,9Mpa) com a tensão mais alta em direção axial ocorrendo no ângulo formado entre a haste do parafuso do pilar e sua cabeça $(240,7 \mathrm{Mpa})$. Para o torque de $20 \mathrm{Ncm}$ simulado no parafuso de titânio do pilar o limite máximo de elasticidade foi de $52 \%$ da resistência ao escoamento. Depois do carregamento do parafuso de retenção de ouro a força total de contato na interface do parafuso foi de $131,5 \mathrm{~N}$, assim como a força de contato na interface cilindro de ouro/pilar. A força de contato na interface implante/pilar aumentou 20,2\% para 226,4N em direção axial. Existiu uma diminuição de 49,8\% na força total de contato, no pilar, na interface pilar/parafuso para $94,0 \mathrm{~N}$ da força de contato inicial de $187,2 \mathrm{~N}$. As maiores tensões foram 
observadas na união entre a haste do parafuso e sua cabeça. A máxima tensão foi 222,2Mpa em direção axial e de 91,7Mpa em direção transversa, sendo a tensão máxima de 39,3\% da resistência ao escoamento.

Preocupado com as variáveis clinicas que afetam as cargas das próteses sobre implantes, WEINBERG; KRUGER ${ }^{115}$ neste mesmo ano, realizaram uma avaliação comparativa das cargas no parafuso de ouro, parafuso do pilar, e no implante em quatro diferentes situações clínicas que incluíram: inclinação cuspídea, inclinação do implante, desvio horizontal e vertical do implante. Através de uma configuração prótese-implante com dimensões conhecidas (utilizadas como padrão), um modelo matemático foi utilizado para calcular o momento de torque no parafuso de ouro e do pilar e na porção coronal do implante. Concluíram que:

1. Para cada $10^{\circ}$ de aumento na inclinação da cúspide, houve aproximadamente um aumento de $30 \%$ na carga do conjunto prótese/implante.

2. Para cada $10^{\circ}$ de aumento na inclinação do implante houve aproximadamente um $5 \%$ de aumento na carga no conjunto prótese/implante

3. Para cada $\mathrm{mm}$ de desvio lingual do implante houve um aumento de $15 \%$ no momento de torque.

4. Para cada $\mathrm{mm}$ de desvio apical do implante houve um aumento de aproximadamente $4 \%$ do momento de torque.

BASTEN et al. ${ }^{9}$, em 1996, compararam as propriedades de fadiga de dois sistemas de implante/pilar Nobel Biocare utilizados na prática clinica quando apertados com três diferentes valores de torque. Este estudo de laboratório 
simulou uma situação clínica, sendo investigado: (1) o numero de ciclos de carga de fadiga requeridos para criar falhas nos pilares ceraone e esteticone; (2) se existia um efeito na carga de fadiga nos sistemas de pilares ceraone e esteticone quando o torque foi aumentado ou diminuído $20 \%$ do valor de torque recomendado pelo fabricante. Os implantes foram incluídos em resina epóxica utilizando-se um dispositivo, onde o diâmetro do implante foi centralizado na resina. O torque foi aplicado utilizando-se um torquímetro Tohnichi 9 BTG-A, calibrado com uma precisão de $0,6 \mathrm{Ncm}$. Sobre os pilares (ceraone e esteticone) um cilindro de ouro foi colocado, encerado e fundido com uma liga metálica (Degudent H / Degussa), sendo que no pilar ceraone um orifício foi realizado no topo da fundição para permitir o aperto do parafuso, e a supra-estrutura foi reposicionada ao pilar e cimentada com cimento fosfato de zinco. No pilar esteticone a supra-estrutura fundida e finalizada foi parafusada com o torque requerido. Uma máquina de fadiga foi utilizada para aplicar uma tensão senoidal em cada amostra, sendo que a máquina parou quando existiu uma falha da amostra. A carga foi aplicada com uma angulação de $30^{\circ}$, simulando uma inclinação cuspídea. A máquina foi programada para aplicar uma carga cíclica a $16 \mathrm{~Hz}$ e $70 \mathrm{~N}$ durante todo o teste. Após 2000 ciclos a máquina foi parada e os parafusos reapertados no valor de torque especificado, depois reiniciada até a falha de um dos componentes. Os resultados mostraram no pilar ceraone que dez dos 15 implantes fraturam entre 15.000 e 676.000 ciclos; em nove amostras a fratura foi localizada abaixo do final do parafuso de ouro; na décima amostra tanto o implante quanto o parafuso do pilar fraturaram ao mesmo nível. Quatro parafusos do pilar falharam entre 169.000 e 1.492 .000 ciclos. No pilar esteticone só um parafuso do pilar de titânio fraturou, nenhum dos parafusos de ouro 
falharam. Todos os outros parafusos falharam na parte das roscas, próximo da haste, estas fraturas foram localizadas aproximadamente $2 \mathrm{~mm}$ abaixo do topo do implante. Uma significativa diferença estatística foi encontrada entre os dois tipos de pilares e entre os diferentes níveis de torque utilizados em cada sistema. Os autores concluíram que: (1) Existem diferenças estatisticamente significantes entre os dois pilares testados em relação ao numero de ciclos para a falha; (2) não houve diferença estatisticamente significante em relação aos ciclos para a falha para três grupos do esteticone e três grupos do cereone; (3) o elo fraco do sistema esteticone está no parafuso de titânio do pilar e não no parafuso de retenção de ouro; (4) em 10 das 15 amostras do sistema ceraone o elo fraco foi o implante de titânio; (5) em 4 das 15 amostras do sistema ceraone foi o parafuso de ouro do pilar.

BINON; MACHUGH ${ }^{15}$, em 1996, avaliaram a influência da liberdade rotacional em implantes de hexágono externo de dimensões diferentes, na estabilidade da união parafusada. No seu experimento, utilizaram dois grupos diferentes de pilares UCLA não segmentados, sendo um grupo com pilar hexagonal pré-fabricado em ouro com seu parafuso de fixação de titânio; e outro grupo com pilar hexagonal fundível em plástico e seu correspondente parafuso de fixação. Com estes, pilares cônicos total metálicos foram obtidos com 8mm de altura por 8mm de largura. Como grupo controle utilizaram pilares pré-fabricados em ouro. Nas amostras, foram aplicados $20 \mathrm{Ncm}$ de torque inicialmente e depois do primeiro milhão de ciclos foram reapertados a $30 \mathrm{Ncm}$. Em todas as amostras foram aplicadas cargas cíclicas utilizando a metodologia desenvolvida por Binon previamente, com 133,3N de carga, uma rotação anti-horária de 28 ciclos por minuto, 1,150 ciclos por minuto de carga vertical até ocorrer a falha do parafuso. 
Seus resultados mostraram uma média de liberdade rotacional de $5^{\circ}$ em ambos grupos testes, sendo todas as amostras do grupo pré-fabricado afrouxaram entre 384.215 e 409.170 ciclos, na primeira parte do experimento. No segundo grupo teste, só um implante falhou em 597.366 ciclos, as outras amostras permaneceram estáveis no primeiro milhão de ciclos, sendo que o segundo grupo teste teve uma maior resistência ao afrouxamento, na primeira e segunda parte do experimento. Encontrou-se também uma correlação direta entre a liberdade rotacional entre o pilar/implante e o afrouxamento do parafuso; sendo que esta união é mais resistente ao afrouxamento quanto menor é a liberdade rotacional.

Avaliando a compatibilidade de alguns parafusos de ouro disponíveis no mercado JAARDA; RAZZOOG; GRATTON ${ }^{48}$, no ano de 1996, fizeram um trabalho onde foram testados 5 parafusos (ouro e titânio) de 3 marcas comerciais: 3 i ; ImplaMed; Implant Support Systems tendo os parafusos Nobelpharma como controle. Os parafusos de ouro foram rosqueados a um torque de $10 \mathrm{Ncm}$ através de um torquímetro. Quando a variabilidade entre-sistemas não era maior que a variabilidade intra-sistemas, o parafuso era considerado compatível. O teste de resistência á tração foi realizado, sendo que os parafusos receberam carga até a sua fratura. Todos os parafusos foram significativamente diferentes quando comparados ao da Nobelpharma e quando comparados entre si. Houve também grande variabilidade nos resultados em relação ao tipo de liga utilizadas. Os autores concluíram que a grande variabilidade entre os parafusos testados em relação a resistência á tração pode influenciar o sistema.

No ano de 1996, CARR et al. ${ }^{22}$, estudaram a resistência do parafuso de ouro e a carga a que o mesmo está submetida quando se variam os componentes com os quis são fabricados as próteses. Os autores confeccionaram próteses 
sobre pilares convencionais, usando cilindros de ouro pré-fabricado e outras, usando cilindros de plástico. Instalaram as próteses e estudaram o efeito sobre o parafuso de ouro. Concluíram que os parafusos de ouro seguram as próteses fabricadas com cilindros de ouro estavam em condições de carga muito melhores que aqueles que prendiam as próteses fabricadas sobre os cilindros de plástico. Observaram também que os cilindros de plástico sofrem mais alteração nos resultados finais quando se variavam os procedimentos laboratoriais, como, por exemplo: variando a liga, o tipo de revestimento ou tipo de acabamento. Concluíram que o uso do cilindro pré-fabricado em ouro oferece vantagens em relação à magnitude de carga e à precisão dos parafusos de ouro.

KANSU; AYDIN ${ }^{59}$, em 1996, avaliaram o potencial de 10 ligas para confecção de próteses em relação à toxidade e à alergia. Em uma primeira parte do estudo, foram comparadas a biocompatibilidade dos materiais em teste histopatológico. As ligas: Au; Au-Pd-Ag-Pt; Au-Pd-Ag; Ag-Pd; Pd; Au-Pd-Ag; PdAg; Cr-Ni; Cr-Co-Cr-Co, juntamente com uma liga de ouro de 22 quilates, foram avaliadas histopatologicamente com uma implantação subcutânea. Cada disco do material foi implantado por 15, 30 e 60 dias em 111 ratos. Foram observados, durante a evolução dos testes, edema, proliferação capilar, alteração da espessura epitelial, fibrose, infiltrado de plasmócitos, infiltrado de linfócitos, hialinização e infiltrado de células gigantes. Para determinar a contagem, foi utilizado o seguinte gabarito: não apresentavam reação (-); reação leve (+); reação moderada $(++)$; reação severa $(+++)$. O grupo controle foi o de ouro de 22 quilates e para a análise foi utilizado um microscópio 40x. Respostas amenas ocorreram para as liga de ouro de 22 quilates. Uma resposta mais vigorosa é observada para amostra de Ni-Cr. Para as amostras Au e Pd as respostas foram 
similares. Para o grupo com baixo conteúdo de ouro e para o paládio prata houve um bom desempenho entre metal básico e precioso. Histologicamente, o grupo com liga não nobre em relação à liga nobre demonstrou reação tecidual mais vigorosa. O metal do grupo $\mathrm{Cr}-\mathrm{Ni}$ (Wiron-88) demonstrou uma forte resposta quando comparados com Cr-Co (Wirocast and Wironium). O estudo enfatiza, então, a necessidade de se observar e tomar cuidado com as características biológicas e relacionando as propriedades do metal selecionado para prática clínica.

KANSU; AYDIN ${ }^{60}$, em 1996, utilizaram o sal das ligas para observar o potencial alérgico desses metais usando testes subcutâneos, tentando assim revelar a importância do potencial biológico dessas ligas para serem selecionadas na prática clínica:

SAL

- Sulfato de Níquel

Cr-Ni (Wiron-88)

- Dicromato de potássio----------- Cr-Ni (Wiron-88)

Cr-Co (Wirocast, Wironium

- Nitrato de prata Au-Pd-Ag (GoldEWL-G, Argenco 9)

Pd-Ag (EWL-G, Argenco 9)

- Nitrato de cobalto

Cr-Co (Wirocast Wironium)

- Sulfato de Níquel

Cr-Ni (Wiron-88)

- Sulfato de Cobre

$\mathrm{Au}$ (22 carat)

- Cloreto de paládio Au-Pd-Ag-Pt (Iropal W)

Au-Pd-Ag (Argenco 9, Gold EWL-

G)

Pd (Argipal)

- Cloreto de platina

Au-Pd-Ag-Pt (Iropal W)

- Cloreto de ouro

$\mathrm{Au}$ (22 caract) 
No grupo controle foi utilizado líquido estéril de petróleo. Os resultados foram anotados após 72 horas do teste cutâneo em que foi usado o seguinte critério: 0 - Resposta negativa; $1(+)$ - eritema; 2(++) eritema + edema; 3(+++) eritema + edema bolha. Os resultados dos testes usando a solução de sal dos metais apresentaram uma severa reação alérgica de 5\% da solução do sulfato de níquel em relação ao grupo controle, sendo que o dicromato de potássio e nitrato de cobalto também apresentaram uma severa reação alérgica. O nitrato de prata e o sulfato de cobre propiciaram reação alérgica moderada. O cloridrato de paládio, cloridrato de cobre e o cloridrato de ouro não apresentaram nenhuma reação alérgica. Dessa forma, concluíram que as propriedades físicas e químicas levaram à escolha da liga, devendo-se tomar cuidado com histórias de alergia ao metais. Os pacientes deveriam ser beneficiados com teste subcutâneo evitando assim a contaminação por níquel.

Através de um estudo de análise tridimensional de elemento finito, SERTGÖZ ${ }^{97}$, em 1997, simulou uma situação de prótese total fixa no arco mandibular, suportada por 6 implantes localizados na região anterior e com extensões em cantilever bilaterais de $16 \mathrm{~mm}$. A finalidade do trabalho era determinar a melhor combinação de materiais para a confecção da restauração protética quanto à infra-estrutura e ao material da superfície oclusal. Para tanto, utilizou resina acrílica, resina composta e porcelana como materiais para a superfície oclusal e ligas de ouro, prata-paládio, cobalto-cromo e titânio, como materiais para a infra-estrutura. Uma carga vertical total de $172 \mathrm{~N}$ foi empregada, o que correspondia à média de força durante a mastigação em uma prótese fixa implanto-suportada mandibular, com duas unidades em cantilever posterior bilaterais, ocluindo contra prótese total superior. Os pontos de aplicação estavam 
localizados no centro dos implantes terminais, no final das extremidades livres, à meia distância entre o centro dos implantes terminais e o final dos cantileveres e também em 4 pontos distribuídos na região anterior, entre os implantes distais. O estresse gerado no tecido ósseo ao redor dos implantes foi de pequena magnitude. Os estresses máximos foram bem inferiores aos limites de tração e compressão do osso cortical e medular. A utilização de materiais mais resilientes para a confecção da infra-estrutura não alterou o prognóstico biológico das próteses fixas implanto-suportadas, não havendo efeito deletério no tecido ósseo. A utilização de um material mais rígido para a confecção da infra-estrutura diminuiu o estresse gerado nos parafusos de ouro. Isso, provavelmente, significa que a alta resistência da infra-estrutura à torção reduz o risco de sobrecarga mecânica nos parafusos de retenção, especialmente em infra-estruturas com extensões em cantilever. Sugeriram que a utilização de materiais mais rígidos poderia prevenir falhas protéticas. Biomecanicamente, a infra-estrutura em liga de cobalto-cromo com a superfície oclusal em porcelana foi a melhor combinação de materiais encontrada.

LEINFELDER $^{69}$, em 1997, em uma revisão de literatura, discutiu alguns dos mais recentes achados relatados sobre os sistemas de ligas que possibilitam uma boa resposta do tecido. Inicialmente, as ligas à base de ouro eram usadas para confecção de inlays, onlays e coroas e pontes. Porém ocorreu a introdução na década de 50, das ligas $\mathrm{CoCr}$ e $\mathrm{NiCr}$ devido ao alto custo do ouro. Então, $\mathrm{CoCr}$ e $\mathrm{NiCr}$ apresentam propriedades necessárias a essa substituição: 1) módulo de elasticidade ou de dureza alto e 2) o estresse requerido para deformação desse metal teve que ser muito maior do que para ligas de ouro e também pelo aumento do módulo de elasticidade permitir que haja mais espaço para acomodar a 
porcelana. Porém, a temperatura de fundição dessas ligas é mais alto do que a das ligas de ouro. A adaptação marginal é aceitável comparando ao ouro. Este metal é biologicamente aceito. O níquel-cromo no meio bucal não apresenta corrosão e dissolução, apresentando uma segurança a respeito de indicação de alergia ou ocorrência de lesões intrabucais. O autor concluiu que a principal razão para o uso dessas ligas é o custo, não colocando em risco os pacientes por não apresentarem propriedades alérgicas.

SCHULTE; COFFEY ${ }^{96}$, em 1997, preocupados com a fratura ou desaperto do abutment e parafuso de retenção, realizaram um estudo onde avaliaram a habilidade de retenção de 9 sistemas de abutment (Lificore biomedical, CHASKA, M.N), onde os abutment eram parafusados para coroas cimentadas, abutment UCLA, abutment cônico com cinta de 1, 2, 3mm, abutment sustentado por uma prótese parafusada, abutment de $5 \mathrm{~mm}$ para coroas cimentadas e abutment para sustentar uma prótese separada. Os parafusos de retenção das coroas eram de ouro e titânio e receberam o torque de $10 \mathrm{Ncm}$. Os parafusos dos abutments receberam 30Ncm de torque (DTG-12; John Chatillon \& Sons, Inc., Greensborc, NC), e foram soltos e rapertados em 10min, 20min e 24 horas do aperto inicial. A media de retenção para os parafusos do abutment para coroas cimentadas foi de $23,6 \mathrm{Ncm}$ e para o parafuso do UCLA foi de $23,9 \mathrm{Ncm}$, o parafuso do abutment cônico com cinta de $1 \mathrm{~mm}$ foi de $24,0 \mathrm{Ncm}$ e são menos retentivos que os demais grupos. Porém o parafuso para abutment para prótese destacável apresenta a maior retenção com média de $28,4 \mathrm{Ncm}$ comparando com os outros parafusos a média foi de $25,7 \mathrm{Ncm}$, não apresentando diferença estatística. Para os parafusos de retenção o parafuso de ouro apresentou mais resistência $8,1 \mathrm{Ncm}$ que o de titânio 7.1Ncm. Então concluiu-se: devemos selecionar um abutment ideal e o 
torque para os parafusos de $30 \mathrm{Ncm}$ eliminando o parafuso de retenção das próteses.

Em 1998 observando a freqüência de afrouxamento de parafuso de ouro McGLUMPHY; MENDEL; HOLLOWAY ${ }^{77}$, ofereceram soluções práticas para minimizar estes problemas clínicos. Muitos produtos, componentes e técnicas têm sido sugerida para manter o parafuso estável. Estas sugestões incluem rosca antivibracional, interligação mecânica direta, alterações no desenho do parafuso, e mecanismo de controle de torque. Todas estas idéias têm ajudado a minimizar o problema de afrouxamento do parafuso, mas nenhuma tem eliminado problema completamente. O afrouxamento do parafuso pode causar maiores problemas, tais como perda óssea ou fratura do implante. Existem dois fatores envolvidos na conservação do parafuso do implante apertado: (1) aumentar a força de travamento, e (2) diminuir as forças de separação.

Para conseguir uma união segura, os parafusos devem ser tensionados para produzir uma força de travamento maior que a força externa que tende a separar. No desenho de um parafuso de junta rígida, o mais importante do ponto de vista funcional é a força de travamento inicial desenvolvida pelo aperto do parafuso. A força de travamento é usualmente proporcional ao torque. Um pequeno torque pode permitir a separação da união e resultar na fadiga do parafuso ou afrouxamento. Um grande torque pode causar falha do parafuso ou tirar a rosca do parafuso. Aplicado ao torque desenvolve uma força dentro do parafuso chamada pré-carga que é uma carga inicial no parafuso em tensão Esta força de tensão no parafuso desenvolve uma força compressiva entre as partes. Entretanto, a pré-carga do parafuso é igual á força de travamento em magnitude. A pré-carga é determinada pelos seguintes fatores: 
1. torque aplicado

2. liga de parafuso

3. desenho da cabeça do parafuso

4. liga do intermediário

5. superfície do intermediário

6. lubrificante

O torque é controlado pela resistência mecânica do parafuso e o modo como é aplicado. O valor do torque ótimo pode ser calculado pelo apertamento da parafuso até que ele falhe. $75 \%$ deste valor é um torque ótimo para aplicar no parafuso. Desta maneira, uma força de travamento significante pode ser desenvolvida com o mínimo de risco de fratura do parafuso.

Os incidentes de afrouxamento pela resistência do parafuso aumentam se uma infra-estrutura não passiva é forçada a se adaptar pelo apertamento do parafuso. A infra-estrutura original aplicada a forças de separação da união com o sistema devido á tentativa de retornar á posição original. Todas as infra-estruturas não passivas devem ser seccionadas e soldadas para garantir uma adaptação passiva.

É muito pequeno o conhecimento da condição do conjunto parafuso e abutment antes da carga e depois do desenvolvimento da carga. LANG et al. ${ }^{65}$, em 1999, examinaram a força do aperto transmitido para o implante com e sem o uso do dispositivo contratorque durante o aperto do parafuso do abutment. Para este experimento foram usados 30 implantes $3,75 \times 10 \mathrm{~mm}$ (SDCA 065, Nobel Biocare AB Göteborg Sweden) e 10 implantes com plaforma 5x10mm (SDCA 6660 Nobel Biocare $A B$ ). Os 30 implantes 3,75 x 10mm foram divididos em grupos de 10 implantes onde 10 abutment tipo Ceraone (SDCA 068), esteticone (SDCA 136) e Procera foram selecionados para cada implante deste grupo, e os outros 10 
implantes 5x10mm receberam abutment Ouro-Adapt (DCA 1086-0). Um implante e um abutment formam uma amostra. Os grupos foram subdivididos em grupo 1A, 2A, 3Ae 4A; Grupo 1B, 2B, 3B e 4B onde o A era apertado pelo controlador de torque e sem o uso do contra torque e o B usava o dispositivo de contra-torque. As amostras foram posicionadas de uma forma seguramente dominado pelo torquimetro BTG-6 Tohmichi e também serviu para marcar de gabarito para transmissão de força. A média de torque para o grupo $1 \mathrm{~A}$ foi $28,62 \mathrm{Ncm}$ e $1 \mathrm{~B}$ $2,90 \mathrm{Ncm} ; 2 \mathrm{~A} 19 \mathrm{Ncm} ; 2 \mathrm{~B} 1,80 \mathrm{Ncme}$ para o procera $3 \mathrm{~A} 30,10 \mathrm{Ncm}, 3 \mathrm{~B} 2,20 \mathrm{Ncm}$; OurAdapt 4A 38,40Ncm, 4B 3,50Ncm. Apresentou uma diferença significativa com a ausência do dispositivo de contra torque. Em média $91 \%$ da carga recomendada para o aperto do parafuso foi transmitida para a interface osso/implante na ausência do dispositivo de contra-torque, e menos de $10 \%$ da carga do aperto do parafuso foi transmitido para o implante quando o dispositivo contra torque foi utilizado. Então o contra torque deverá sempre ser usado para evitar que forças excessivas sejam transmitidas para o implante.

FAULKNER; WOLFAARDT; CHAN $^{33}$, em 1999, determinaram se o Perioteste têm potencial para detectar clinicamente o afrouxamento do parafuso do pilar nas restaurações de próteses sobre implantes, determinando-se dessa forma a efetividade do periotest em detectar mudanças na rigidez da união, no estudo também foram comparadas medidas subjetivas realizadas por três clínicos experientes. Foi desenhado um dispositivo especial, onde foram fixados rigidamente quatro implantes aos quais foram unidos pilares com um torque de $10 \mathrm{Ncm}$. Após calibração do instrumento uma serie de torque de 20 , 32, e 45Ncm foram aplicados, sendo posteriormente afrouxados. Os resultados mostraram que o Periotest foi encontrado ser mais sensível do que a detecção manual para 
avaliação do afrouxamento do parafuso do pilar; entretanto o instrumento não foi sensível ou suficiente para indicar deterioração do afrouxamento do parafuso antes da perda da pré-carga.

Com o objetivo de avaliar comparativamente o grau de micro infiltração de fluídos, na interface implante/pilar GROSS; ABRAMOVICH; WEISS ${ }^{41}$, neste mesmo ano, avaliaram cinco sistemas de implantes comercialmente disponíveis. Três conjuntos pilar / implante de cada um dos sistemas Spline, ITI, Nobelpharma (ceraone), Steri-Oss, e 3i, foram utilizados, sendo que para o experimento torques de aperto de $10 \mathrm{Ncm}, 20 \mathrm{Ncm}$, e o torque recomendado pelos fabricantes foram aplicados. Os conjuntos implante/pilar, foram imerso em uma serie de tubos de silicone, contendo corantes de baixo peso molecular, os quais foram imersos em água destilada a uma pressão de ar constante, para evitar a passagem passiva dos fluidos através da interface. Leituras foram realizadas em intervalos de 5, 20, e 80 minutos desde o tempo de ativação da pressão inicial. Antes de cada leitura, os constituintes do tubo primário foram misturados para assegurar a distribuição homogênea do corante e transferidos para um micro tubo secundário de $0,6 \mathrm{ml}$, para a realização das leituras em um espectofotômetro. Os resultados mostraram um aumento gradual na microiinfiltração com o passar do tempo, para todas as amostras observadas. Como as três amostras iniciais do sistema Steri-Oss mostraram médias e desvios padrão consideravelmente mais altos que os outros sistemas, o número de amostras foi aumentado para sete, sendo que ainda assim foram encontrados valores médios de microinfiltração notavelmente mais altos. Quando as amostras foram comparadas quanto ao torque aplicado, foi encontrada uma interação entre o valor de torque e o grau de micro-infiltração, sendo que esta diminuiu significativamente na medida que o torque aumentou de 
$10 \mathrm{Ncm}$ para $20 \mathrm{Ncm}$, até o torque recomendado pelos fabricantes. Diferenças estatisticamente significantes foram encontradas entre os sistemas testados.

GROSS et al. ${ }^{40}$, em 1999, avaliaram o torque de aperto gerado de forma manual por nove clínicos experientes em prótese sobre implantes utilizando cinco diferentes sistemas de implantes. Na metodologia empregada, uma condição clínica foi simulada sobre um manequim odontológico no qual foi fixado um implante na área de um primeiro molar maxilar direito. Neste, os clínicos foram orientados a aplicar cinco vezes o torque que normalmente usam sob condições clínicas (torque habitual); e cinco vezes o máximo torque que eles poderiam aplicar (torque máximo), utilizando a chave de cada sistema; sendo que entre cada torque aplicado um descanso mínimo de 30 segundos foi permitido. Para as leituras do torque gerado por cada clínico, o implante foi conectado a um torquímetro (Tohnichi/Japan), que foi fixado no manequim. Os resultados mostraram uma variabilidade no torque produzido por cada clínico e entre os diferentes clínicos; sendo que no torque habitual foram encontradas médias de 7,0 a $14,6 \mathrm{Ncm}$ o que significa uma média de porcentagem de 29 a $55 \%$ do torque recomendado pelos fabricantes. Quando o torque máximo foi aplicado foram encontrados valores entre 9,4 a 19,9Ncm, uma média de porcentagem de 32 a $76 \%$ do torque recomendado pelos fabricantes, em nenhum dos testes os clínicos atingiram os níveis de torque recomendados pelos fabricantes, sendo demonstrada uma alta inconsistência na geração do torque nos diferentes sistemas testados

STANDLEE; CAPUTO ${ }^{102}$, ainda neste mesmo ano, avaliaram a precisão de sete dispositivos de torque eletrônicos (Nobel Biocare modelo DEA-020) em uso clinico. No seu experimento, desenvolveram uma metodologia onde utilizaram um 
torno em miniatura como implante teste para transferir a rotação gerada pelos dispositivos a uma máquina de testes Instron. Dez repetições foram realizadas por cada dispositivo em cada nível de torque de 10, 20 e $32 \mathrm{Ncm}$. Os resultados obtidos mostraram que os dispositivos foram precisos, porém inexatos, ou seja, eles tiveram um pequeno desvio padrão, mas o torque gerado foi diferente em relação ao torque para o qual foram programados, com uma ampla variação do torque gerado pelos dispositivos do mesmo modelo. No torque de $10 \mathrm{Ncm}$, foi observada uma tendência a gerar valores de torque superiores aos programados $(-22 \%$ a $+165 \%)$. Em $20 \mathrm{Ncm}$ as médias de torque foram mais próximas ao programado $(-40 \%$ a $+40 \%)$, enquanto que em $32 \mathrm{Ncm}$, foi observada uma tendência a aplicar um torque baixo $(-44 \%$ a $+14 \%)$ do torque programado. Os autores acreditam que quando um sobre torque é aplicado nos parafusos, uma maior pré-carga é gerada ou deformação plástica e fratura do parafuso podem ocorrer; entretanto quando um torque baixo é aplicado existe uma maior possibilidade de afrouxamento do parafuso.

GIL et al. ${ }^{36}$, em 1999, relataram um estudo com o propósito de comparar a corrosão e o comportamento de íons metálicos. As ligas utilizadas foram 6: Ti (Rematitan), Au-Ag-Pd (argenco 4); Ag-Au-Pd (Selector 3); Pd (Cerapall 2), AgPd (Aldenor 40), NiCr (Verabond). Um microscópio óptico (MEF 4, Olympus, Japão) foi utilizado para observar o processo de corrosão. A corrosão das superfícies foi observada por um microscópio elétrico de varredura (JEOL 6400, Japão). As medidas foram feitas em 1, 3, 5, 10, 24 e 120 horas. Avaliaram-se a resistência e a corrosão de 6 ligas metálicas utilizadas e Odontologia clínica, medindo a resistência e a polarização em meio a uma saliva artificial. Avaliou a densidade crítica da corrente (JCR), densidade da corrente passiva (ip) e o potencial de 
corrosão (Ecr) e a depressão crítica. A liberação de íons metálicos das diferentes ligas foram analisadas em um meio de saliva a $37^{\circ} \mathrm{C}$ e $\mathrm{pH} 6,7$. A liga de níquelcromo exibiu uma corrosão (-100Mv) e uma grande quantidade de liberação de íons $\left(19 \mathrm{Ma} / \mathrm{cm}^{2}\right)$. A de titânio apresentou um baixo valor de liberação de íons $\left(0,85 \mathrm{Ma} / \mathrm{cm}^{2}\right)$ e uma boa resistência à corrosão $(-20 \mathrm{Mv})$ devido a uma película passiva na superfície do metal. A liga com alto conteúdo de ouro Au-Ag-Pd, (15Mv) apresentou-se melhor em relação às outras ligas testadas.

No mesmo ano SARTORI ${ }^{98}$, comparou a interface que se estabelece entre intermediários do tipo estético de diversas empresas e seus respectivos cilindros protéticos, fabricados em materiais diferentes. Foram selecionados os cilindros das empresas: Nobel Biocare, 3i e Conexão, fabricados em ouro, e Conexão e Carbontec, produzidos em plástico. A observação marginal, realizada em microscópio ótico, encontrou medidas que variaram de 5,7 a 10,49um quando os cilindros eram fabricados em ouro e de 17,8 a aproximadamente $20,0 \mu \mathrm{m}$ quando eram fabricados em plástico. Após as leituras iniciais, os cilindros receberam enceramento, foram incluídos e fundidos com ligas à base de ouro, de prata/paládio e de níquel/cromo e novamente analisados. As medidas variaram de 5,8 a $20,4 \mu m$ quando os cilindros de ouro foram fundidos com as ligas de ouro e prata/paládio, e de 32,10 a $141 \mu \mathrm{m}$ quando os cilindros em plástico foram trabalhados de forma similar, porém com a liga de níquel-cromo. Os resultados demonstraram que os cilindros usinados em plástico sofrem variabilidade de comportamento quando à estabilidade dimensional das margens, em grau maior do que os cilindros usinados em ouro.

CASTILIO $^{24}$, em 2000, avaliou a adaptação da interface intermediário/componentes protéticos (cilindro), fundidos, em titânio e cobalto- 
cromo, em monobloco e após a realização de soldagem a laser. Utilizou 30 cilindros de plástico torneados e 15 barras cilíndricas para conexão dos mesmos. Cada corpo de prova era constituído de 3 cilindros unidos entre si, num total de 10 corpos de prova, sendo que 5 foram fundidos em titânio e 5 em cobalto-cromo. Foram realizadas análises e mensurações das interfaces antes e após a soldagem a laser através de um microscópio comparador. As infra-estruturas fundidas em monobloco apresentaram uma maior interface, com desajuste médio de $26,164 \mu \mathrm{m}$ e $19,943 \mathrm{~m}$ após a soldagem a laser. Houve diferenças estatisticamente significantes entre os dois materiais utilizados, obtendo-se um desajuste médio de $21,262 \mu \mathrm{m}$ para as infra-estruturas de titânio e 24,845 $\mu \mathrm{m}$ para as de cobalto-cromo. Os resultados não mostraram interação entre as três condições estudadas (material, técnica e cilindros). A autora sugeriu que estudos devem ser realizados para testar diferentes materiais e tecnologia, pois a contribuição para o avanço da ciência é fundamental, assim como para a redução de custo das próteses sobre implantes.

ABOYOUSSEF; WEINER; EHRENBERG ${ }^{1}$, no ano de 2000, avaliaram uma forma de aumentar a resistência ao afrouxamento da união coroa / pilar; realizando quatro sulcos em forma de $v(1 \times 1 \mathrm{~mm})$ ao redor da área periférica dos pilares (pilares modificados). No estudo três desenhos de pilares para testar a resistência a forças rotacionais, foram utilizados, sendo estes: convencionais de $3 \mathrm{~mm}$, convencionais modificados e esteticones. Cada grupo foi fixado sobre análogos de implantes (3i), e aplicado um torque de $20 \mathrm{Ncm}$ utilizando um dispositivo eletrônico de torque. Em cada amostra parafusos de ouro hexagonais foram apertados sobre os pilares com $10 \mathrm{Ncm}$ de torque. Uma força rotacional foi aplicada até a falha na união pilar/implante ou na união cilindro de ouro/pilar 
ocorrer. Seus resultados mostraram um afrouxamento do parafuso nos três grupos testados, não ocorrendo nenhuma fratura. Nos grupos esteticone e convencional modificado o afrouxamento ocorreu na interface pilar/implante, enquanto que no grupo convencional na interface cilindro de ouro/pilar. Uma média de falha, de $70 \mathrm{Ncm}$ e $71 \mathrm{Ncm}$ de torque, para o grupo convencional modificado e esteticone respectivamente; no grupo convencional a média de falha foi de $21,28 \mathrm{Ncm}$. Os autores concluíram que a adição de característica de forma de resistência anti-rotacionais aumentam o comprimento do braço de alavanca o que pode ser um fator importante na resistência da perda da pré-carga causada pela ação do torque.

Discutindo os principais aspectos de uma conexão de hexágono externo e a estabilidade do parafuso nesta união, BINON ${ }^{13}$, neste mesmo ano, descreveu os princípios de funcionamento dos componentes e cada um dos fatores que podem levar a falhas da interface pilar/implante. Segundo o autor, a função básica do parafuso é criar uma força de travamento entre as duas partes da conexão, de forma a prevenir a separação, perda da tensão e evitar afrouxamento quando exposto a vibração ou cargas cíclicas externas. O aperto cria uma tensão tanto na cabeça do parafuso que assenta no pilar, como entre as roscas internas do implante e as roscas do parafuso; essa tensão é denominada de pré-carga, sendo esta, diretamente proporcional ao torque aplicado. Vários fatores podem prejudicar a pré-carga e conseqüentemente a estabilidade da união. Rugosidade da superfície, deformação plástica, interação elástica, fricção, temperatura, fluídos corrosivos, dobramento, desalinhamento, desadaptação, rigidez, tolerância de usinagem, cargas cíclicas, fadiga, desenho do parafuso e incompatibilidade do material. Ao analisar a superfície dos componentes, afirma que a condição das 
superfícies das partes que entram em contato tem uma influência direta na obtenção de uma adequada força de travamento e manutenção da estabilidade. Quando é aplicada uma pré-carga no parafuso e a força de travamento une as partes, se inicia um processo de achatamento das micro-rugosidades existentes na superfície devido à compressão gerada pelo contato entre as superfícies metálicas; quando estas superfícies se achatam, a distância microscópica diminui, e a força de travamento e a pré-carga reduzem. Para minimizar este efeito, o parafuso deve ser apertado no valor de torque requerido e após cinco minutos realizar um reaperto com o mesmo torque aplicado. Para o autor quando a interface não esta corretamente alinhada devido a desadaptação dos componentes, a união é seriamente comprometida, já que a pré-carga aplicada é direcionada ao alinhamento das partes, e mais pré-carga é requerida para unir as partes, assim o torque aplicado se torna insuficiente para obter uma força de travamento adequada.

CIBIRKA et al. ${ }^{25}$, em 2001, examinaram diferenças no destorque após testes de fadiga em implantes com hexágono externo. Sendo que as dimensões entre o hexágono externo do implante e o hexágono interno do pilar foram alteradas, ou o hexágono externo do implante eliminado. Três desenhos experimentais de implantes foram utilizados no seu trabalho; dez de cada desenho. (1) Implante de plataforma regular de 3,75mm com hexágono externo convencional, tendo uma superfície média de largura hexagonal de 2,700mm e uma altura de $0,633 \mathrm{~mm}$. (2) Implante de plataforma regular de $3,75 \mathrm{~mm}$, com hexágono externo modificado, tendo uma média de largura hexagonal de 2,664mm e uma altura de $0,608 \mathrm{~mm}$. (3) Implante de $3,75 \mathrm{~mm}$ com hexágono removido por desgaste para criar uma forma circular com um diâmetro de 
2,668mm e uma altura de $0,668 \mathrm{~mm}$. Trinta pilares procera CAD/CAM (Nobel Biocare) foram fabricados com uma plataforma de carga inclinada com 25 graus. Os implantes foram fixados rigidamente em um dispositivo especial, e os pilares apertados com um parafuso de ouro a $32 \mathrm{Ncm}$, utilizando-se um controlador eletrônico de torque (Nobel Biocare). O conjunto fixado no dispositivo foi levado a uma máquina de ensaios. Uma carga dinâmica foi aplicada sobre a plataforma de cada pilar por um pistão em uma única direção. A máquina foi controlada com uma carga cíclica entre 20 e $200 \mathrm{~N}$ de força, a oito ciclos por minuto, sendo contínua por 5,000,000 de ciclos. Um exame macroscópico e radiográfico da interface pilar / implante de cada amostra foi realizado. Depois da carga, as amostras foram fixadas em um dispositivo, e com um medidor de torque Tohnichi BTG-6 foram removidos os parafusos e registrados os valores do destorque. Através do exame macroscópico e radiográfico não foi observado afrouxamento ou deslocamento rotacional na interface pilar/implante. A média de destorque nos três desenhos testados foi de $14,40,14,70$, e $16,40 \mathrm{Ncm}$ nos desenhos 1,2 , e 3 respectivamente. Os autores concluíram que o aumento da distância no entre o largo do hexágono externo do implante e o hexágono interno do pilar não produz efeito estatisticamente significante nos valores de destorque do parafuso depois de 5.000.000 de ciclos em testes de fadiga. A eliminação do hexágono externo do implante e no aumento da altura teve um efeito significante nos valores de destorque do parafuso de ouro.

Com o objetivo de testar a precisão de dispositivos eletrônicos de torque Nobelpharma DEA 020 (Nobel Biocare) que estavam em uso clinico por um tempo mínimo de cinco anos, MITRANI et $\mathbf{a l}^{75}$, em 2001, compararam o torque gerado por estes, com o toque gerado por dispositivos novos. No seu trabalho 
desenvolveram uma técnica no laboratório que simulou uma situação clínica utilizando um implante osseointegrado $13 \times 3.75 \mathrm{~mm}$ do sistema Bränemark sobre o qual foi colocado um pilar ceraone, fixado com um parafuso de ouro. Para medir a quantidade de torque produzida por cada dispositivos um medidor analógico de torque Tohnichi 9BTG-A com uma precisão de $\pm 3 \%$ foi utilizado. Os testes de torque foram realizados em 10, 20 e $32 \mathrm{Ncm}$ em alta e baixa velocidade, sendo realizado em cada nível de torque dez repetições para cada dispositivo. Seus resultados não mostraram existir correlação significante entre o torque gerado pelos dispositivos e o tempo em uso; ao comparar os dispositivos em uso clínico com os dispositivos novos, os autores também não encontraram diferenças estatisticamente significantes.

PESUM et al. ${ }^{86}$, em 2001, avaliaram e compararam forças axiais compressivas e torques aplicados simultaneamente em parafusos de ouro por pessoas com diferentes graus de experiência. Para o estudo foi fixado em resina acrílica, um implante osseointegrado (Nobel Biocare) $3,75 \times 8 \mathrm{~mm}$ de comprimento. Um pilar convencional standard de $3 \mathrm{~mm}$ foi unido ao implante por meio do correspondente parafuso, com um torque de $20 \mathrm{Ncm}$. Uma coroa total metálica assentada passivamente ao implante foi unida ao pilar com um parafuso de ouro aplicando-se um torque de $10 \mathrm{Ncm}$. Estudantes sem experiência em restaurações com implantes, residentes de próteses com menos de dois anos de experiência e professores da faculdade com no mínimo de cinco anos de experiência em restaurações com implantes foram orientados a apertar e afrouxar os parafusos de ouro três vezes. A magnitude e duração da força axial compressiva e o torque dado foram avaliados simultaneamente utilizando uma célula de carga em miniatura, adaptada a um dispositivo eletrônico de torque. Os 
resultados mostraram que os professores fixaram os parafusos com uma força axial compressiva maior que os estudantes e os residentes, sendo a quantidade de torque um pouco menor que o recomendado $10 \mathrm{Ncm}$. Os professores tiveram uma menor variação nos procedimentos de aperto e afrouxamento. Concluindo que pessoas com uma maior experiência na área, tem uma maior consistência nos procedimentos de aperto e afrouxamento dos parafusos de ouro. Uma maior força axial compressiva foi aplicada durante o afrouxamento quando comparada com a força de aperto. Forças compressivas removeram parte da pré-carga resultando em quantidade diminuída de torque necessária para remover o parafuso de ouro, o que pode explicar porque os estudos de remoção de torque mostram valores menores durante a remoção do parafuso, do que na sua colocação.

TAN; NICHOLLS ${ }^{106}$, em 2001, mediram e compararam a pré-carga produzida em parafusos de sete diferentes tipos de pilares hexagonais. A medida da pré-carga foi realizada fixando dois strain gauge ao pilar que foi unido a um implante 3,75 x 15mm (Bränemark system, Nobel Biocare). Pilares convencionais standard, esteticone, miruscone, pilar de titânio, ceraone, cilindro de ouro, e tiadpat foram utilizados. Um controlador eletrônico de torque (Nobel Biocare) aplicou 20 ou $32 \mathrm{Ncm}$ de torque em alta e baixa velocidade, seguindo o indicado pelo fabricante, e a pré-carga foi registrada no computador, através dos strain gauges. Os resultados encontrados nos diferentes pilares mostraram médias de pré-carga de $181,6 \mathrm{~N}$ convencionais, $291,3 \mathrm{~N}$ esteticone, $456,5 \mathrm{~N}$ miruscone, 369,7 pilar titânio, 643,4N ceraone, 536,3N cilindro de ouro, e 556,9N tiadapt. Diferenças estatisticamente significantes foram encontradas entre os diferentes sistemas e na velocidade de aplicação do torque. Pilares com parafusos de ouro 
tiveram maiores valores de pré-carga. Dessa forma os autores concluíram que a pré-carga na união implante / pilar depende do desenho, diâmetro, e material do parafuso, assim como do torque de aperto e da velocidade do torque.

Adaptação passiva, segundo SAHIN; ÇEHRELII ${ }^{92}$, em 2001, é sinônimo de uma "adaptação ideal". Teoricamente, uma infra-estrutura deveria proporcionar uma adaptação passiva, o que seria indução de tensão zero nos componentes de implantes e ao osso adjacente na ausência de cargas. Entretanto, uma adaptação realmente passiva é impossível de ser obtida. Os procedimentos clínicos e laboratoriais utilizados na confecção de infra-estruturas são inadequados para propiciar tal adaptação. Complicações protéticas como afrouxamento e fratura dos parafusos, fratura do intermediário, da infra-estrutura e material de cobertura têm sido documentadas e relacionadas à desadaptação das infra-estruturas. Não há estudos clínicos longitudinais comprovando falhas nos implantes atribuídas especificamente à falta de adaptação da infra-estrutura. Uma adaptação marginal aceitável entre os componentes não significa a obtenção de uma adaptação passiva. Sugerem que o método ideal para se determinar a passividade de uma infra-estrutura seria a análise de tensão gerada em cada intermediário e/ou componente protético antes e após o apertamento dos parafusos e/ou cimentação da mesma. Tal procedimento só seria possível com a utilização de strain gauges (extensômetros). Cada passo na confecção de uma infra-estrutura influência a adaptação final e, segundo os autores, os materiais e técnicas utilizados atualmente não são precisos dimensionalmente, havendo necessidade de futuros desenvolvimentos e estudos.

Em 2001, através de revisão da literatura sobre a aplicação da análise de elemento finito em Implantodontia, GENG; TAN; LIU ${ }^{34}$ discutiram sobre os 
achados encontrados com essa metodologia quanto à interface osso-implante, a conexão prótese-implante e próteses implanto-suportadas por vários implantes. Relataram que as propriedades dos materiais simulados influenciam a distribuição e a manutenção dos esforços no modelo de elemento finito e, por isso, resultados de muitos estudos não podem ser generalizados para situações clínicas. O osso, por exemplo, é um material isotrópico. Significa que tem diferentes propriedades quando medido em diferentes direções e a maioria dos estudos avaliados considera os materiais homogêneos e com propriedades lineares. Ligas metálicas com baixo módulo de elasticidade promovem esforços mais intensos na interface osso-implante e recomendaram a utilização de ligas metálicas rígidas para uma melhor distribuição dos esforços. A distribuição dos esforços em próteses suportadas por vários implantes é de grande complexidade, incluindo os seguintes fatores mecânicos: inclinação e posição dos implantes, forma e extensão da infra-estrutura, material da prótese, comprimento do cantilever, interface entre componentes protéticos e implantes e interface osso-implante.

RIBAS; RIBEIRO ${ }^{91}$, em 2001, realizaram uma revisão de literatura e sugeriram indicações das ligas alternativas mais utilizadas para confecção de uma prótese fixa unitária, assim como alguns cuidados na fase laboratorial, de forma a obter sucesso clínico.

Ligas do sistema prata-paládio: essas ligas sem cobre podem conter de $70 \%$ a $72 \%$ de prata e cerca de $25 \%$ de paládio e são semelhantes à liga de ouro tipo III. Outras ligas baseadas na prata podem conter $60 \%$ de prata e $25 \%$ de paládio e cerca de $15 \%$ de cobre, sendo que neste caso suas propriedades se aproximam do ouro tipo IV. A liga de prata-paládio está atendendo de modo 
satisfatório as exigências clínicas e laboratoriais por isso estão sendo indicadas para coroas unitárias metalocerâmicas, próteses fixas, pinos intracanais e RMF.

Ligas do sistema níquel-cromo: As propriedades da liga níquel-cromo foram melhoradas pela adição de pequenas quantidades de berílio em até $2 \%$ no peso diminuindo, assim, o índice de corrosão e manchamento na porcelana. 0 berílio é geralmente adicionado com o intuito de reduzir a temperatura de fusão e melhorar a capacidade de brunimento. Essas ligas têm comportamento clínico semelhante ao das ligas de ouro tipo IV, reduzindo os valores de dureza.

Ligas para metalocerâmica: $\quad$ Têm a capacidade técnica de se unir à cerâmica e podem ser classificadas em ligas nobres e de metais básicos, compartilhando três aspectos em comum: a) potencial de se unir à porcelana odontológica; b) coeficiente de expansão térmica compatível com a porcelana; c) sua temperatura de solidez é suficientemente alta para permitir a aplicação, sobre elas, de porcelana de baixa fusão. As principais ligas para metalocerâmica dividem-se em dois grupos: 1) ligas de metais básicos (níquel-cromo, cromocobalto e outros sistemas); 2) ligas de metais nobres (ouro-platina-paládio, ouropaládio-prata, ouro-paládio, paládio-prata alto conteúdo de paládio). Os autores concluíram que essas ligas apresentam diferentes propriedades mecânicas e composição, implicando cuidados clínicos e laboratoriais específicos para cada liga, sendo que apresentam maior aceitação nos consultórios odontológicos.

No ano de 2002, LEE et al. $^{86}$, investigaram o efeito da mastigação simulada sobre componentes de implantes, utilizando análise de vibração para documentar o mecanismo básico de afrouxamento do parafuso em um meio oral simulado. Um dispositivo pneumático cilíndrico para a aplicação das cargas cíclicas foi fabricado para simular o movimento mastigatório. Sendo que 13 pilares 
standards de $4 \mathrm{~mm}$ de altura foram conectados a implantes de hexágono externo com um parafuso de titânio, no qual foi aplicado um torque de $20 \mathrm{Ncm}$. Em cada conjunto implante pilar foi fixado uma coroa unitária com um parafuso de ouro de $3 \mathrm{~mm}$ onde foi aplicado um torque de $10 \mathrm{Ncm}$. Nos corpos de provas foram aplicadas cargas utilizando o dispositivo mencionado, com uma força de $100 \mathrm{~N}$, em um ângulo de $30^{\circ}$ do eixo do implante, a uma freqüência de $1 \mathrm{~Hz}$. Um grupo controle de 13 corpos de prova com as mesmas características do grupo experimental foi utilizado, onde foram aplicadas cargas axiais com as mesmas especificações. O efeito de um milhão de ciclos e várias forças de torques $(2,4,6$, 8, 10, e 12Ncm), no afrouxamento do parafuso foram avaliados pela análise de vibração. Os resultados mostraram que o modo de vibração foi dividido em quatro estágios, para o afrouxamento dos parafusos de ouro: (1) deslocamento inicial; (2) vibração inicial; (3) deformação elástica; e (4) estágio de recuperação. Entretanto os estágios de deslocamento e vibração inicial não foram perceptíveis no afrouxamento dos parafusos de ouro. Do grupo experimental quatro parafusos de ouro afrouxaram antes de 1.000 .000 de ciclos, e não houve afrouxamento no grupo controle. O afrouxamento do parafuso não teve efeito no estágio de deformação elástica. Concluído-se que o torque de aperto tem um efeito significante no afrouxamento do parafuso, sendo que este torque deveria ser maior de $10 \mathrm{Ncm}$ como recomendado para os parafusos de ouro neste sistema de hexágono externo.

RAFEE et $\mathbf{a l}^{88}$, em 2002, avaliaram o efeito de repetidos torques e a contaminação da saliva na máxima resistência a tração de parafusos de fenda retenção de ouro. Quarenta e cinco parafusos (3i) divididos em nove grupos foram testados, sendo que um grupo OX onde não foi aplicado torque serviu como 
controle. Em quatro grupos sob condições de contaminação foi determinada a resistência à tração em diferentes números de repetições de $10 \mathrm{Ncm}$ de torque: grupo 1X, grupo 5X, grupo 10X, grupo 20X. Estes mesmos grupos sob condições de contaminação também foram testados, conformando-se um total de oito grupos testes e um grupo controle. Os resultados mostraram valores médios de fratura de $97,6 \pm 2,2 \mathrm{~kg}$ (grupo 0X) a 102,0 $\pm 2,1 \mathrm{~kg}$ (grupo 5X); sendo que não foram encontradas diferenças estatisticamente significantes entre os grupos quando estiveram ou não sob condições de contaminação. Em todos os grupos não existiu uma diminuição significativa nos valores de carga para fratura. Os autores sugeriram que os parafusos testados podem ser apertados e removidos acima de 20 vezes sem afetar a máxima resistência tração.

Com o objetivo de comparar a precisão de dispositivos mecânicos de aplicação de torque em próteses sobre implantes, STANDLEE et al. ${ }^{102}$, neste mesmo ano, avaliaram três sistemas de torque. No experimento, utilizaram a mesma metodologia desenvolvida por eles em um trabalho anterior, na qual o torque gerado pelos diferentes dispositivos é transferido a uma máquina Instron através de um torno em miniatura. Seis dispositivos Nobel Biocare (em 10 e 20 Ncm), cinco Strauman ITI (em 15 e 35Ncm), e seis Dyna Torq ITL (em 10, 20 e 30Ncm), foram testados, sendo realizadas um mínimo de dez repetições em cada nível de torque. Os resultados obtidos mostraram que no dispositivo eletrônico Nobel Biocare existiu uma tendência a uma maior precisão na aplicação do menor torque $(10 \mathrm{Ncm})$, porém variações significantes entre $8 \%$ e $41 \%$ foram encontradas nestes dispositivos de forma individual. No dispositivo ITI e ITL, uma menor variabilidade nos valores de torque gerados foi observada, com uma variação não maior de $10 \%$, sendo os valores de torques gerados próximos aos 
programados pelos fabricantes. Concluíram que o torque gerado por cada dispositivo individual tem uma variação em diferentes graus, do torque para o qual os mesmos são programados.

BONACHELA ${ }^{16}$, em 2002, avaliou a adaptação da interface pilar/componentes protéticos, utilizando cilindros de plásticos, fundidos em titânio e cobalto-cromo, em monobloco e após a realização de soldagem a laser em função dos parafusos de fixação desses cilindros, parafusos de ouro e de fenda com aplicação de um torque de $10 \mathrm{Ncm}$. Em seu estudo, utilizou dez amostras, sendo que cada uma estava composta de três componentes protéticos unidos entre si por uma barra. Cinco amostras foram fundidas em titânio e cinco em cobalto-cromo. Mensurações foram realizadas nas interfaces pilar/componente protético com cada tipo de parafuso de fixação, antes e após a soldagem a laser, com a utilização de um microscópio comparador. Seus resultados mostraram não existir em diferenças estatisticamente significantes em relação à liga metálica utilizada, solda e parafusos. Na fundição de liga de cobalto-cromo, a utilização dos parafusos de fenda e de hexágono mostraram diferenças estatisticamente significantes, sendo que na fundição em monobloco uma melhor adaptação para os parafusos de fenda foi observada $(24,13 \mu \mathrm{m})$, quando comparada com os parafusos hexagonais $(27,93 \mu \mathrm{m})$.

DUYCK; NAERT ${ }^{31}$, em 2002, avaliaram a possibilidade de se empregar a cimentação associada a próteses parafusadas sobre implantes como forma de compensar desadaptações. Utilizaram um modelo com 3 implantes, 4 infraestruturas em paládio-prata e 2 tipos de intermediários: cilíndricos e cônicos. As amostras foram primeiro parafusadas e depois parafusadas em associação a um cimento. Através de extensômetros afixados nos intermediários, a pré-carga foi 
medida em 4 diferentes situações: boa adaptação em todos os intermediários, com 1 intermediário desadaptado (100 $\mu$ m verticalmente), com os intermediários 1 e 2 desadaptados $(200 \mu \mathrm{m}$ horizontalmente) e com intermediários 1 e 3 desadaptados (200 $\mu \mathrm{m}$ horizontalmente). A pré-carga externa nos intermediários, medida após o apertamento dos parafusos da prótese, foi utilizada para indicar a qualidade de adaptação. Cada prótese foi submetida a 10 apertamentos com torque de $10 \mathrm{Ncm}$. Os resultados mostraram que as forças axiais foram menores e os valores dos momentos de torção foram maiores nas amostras desadaptadas. O cimento não foi capaz de reduzir a pré-carga externa. Os autores concluíram que este não é um procedimento eficaz, pois, apesar de visualmente compensar desadaptações, não favorece uma melhor transmissão de forças para os implantes.

MURPHY et al. ${ }^{84}$, em 2002, em uma investigação clínica durante 5 anos, realizaram o acompanhamento de infra-estruturas parafusadas confeccionadas com 2 diferentes ligas, com propriedades diferentes. Uma liga utilizada foi o grupo A: ouro (Chicago IV) e a outra grupo B: prata-paládio (Palliag-M). Um mesmo técnico do laboratório executou os procedimentos laboratoriais de alimentação, inclusão e fundição das ligas de acordo com as instruções dos fabricantes. A liga de prata-paládio é muito sensível, e um preciso controle da temperatura de fundição e pressão são essenciais para assegurar a exatidão da adaptação da infra-estrutura. Então as próteses foram parafusadas com torque de $10 \mathrm{Ncm}$. Após a instalação das próteses, foi feito um acompanhamento de 3, 6 e 12 meses, verificando-se a adaptação e, depois de 5 anos, as próteses foram removidas para observar a osseointegração dos implantes. Foi tirada uma radiografia imediatamente na instalação e após 5 anos de instaladas as próteses. Uma 
comparação entre a $1^{\mathrm{a}}$ e a $2^{\mathrm{a}}$ radiografia foi feita em relação à altura óssea, entre as infra-estruturas do grupo A (ouro) e grupo B (prata-paládio), não ocorrendo diferença estatisticamente significantes. Então os autores concluíram que, para uma ótima infra-estrutura sob implantes, deve-se levar em consideração alguns requisitos como a biocompatibilidade, correta fabricação, exatidão na adaptação e uma alta resistência frente à função, e que a liga de prata-paládio pode ser considerada uma substituta para a liga de ouro.

ZITZMANN; MARINELLO ${ }^{117}$, em 2002, apresentaram uma revisão de literatura sobre as opções de próteses implanto-suportadas para pacientes edêntulos. Dentre as alternativas do material da prótese, indicaram a utilização de infra-estruturas em liga áurea, em cobalto-cromo ou em titânio. As técnicas de confecção incluem a fundição em monobloco, a soldagem a laser e a fresagem. Como as ligas metálicas possuem propriedades físicas diferentes, cada uma oferece vantagens e desvantagens, de acordo com a técnica utilizada, com a dimensão da prótese e com o conforto do paciente. Recomendaram a liga de cobalto-cromo para casos em que há pouco espaço oclusal por permitir infraestruturas mais resistentes.

RAMBHIA et al. $^{89}$, em 2002, determinaram a influência de defeitos na resistência a tração de parafusos de retenção de ouro, e examinaram a microestrutura e microdureza, e os principais componentes constituintes de parafusos de duas marcas comerciais (3i e Nobelpharma) e dois lotes diferentes. Dois parafusos 3i, e dois Nobelpharma foram incluídos em resina acrílica e preparados através de procedimentos metalográficos para serem examinados os defeitos, utilizando-se microscopia ótica. A microestrutura da superfície dos parafusos foi examinada por condicionamento das amostras preparadas com 
solução de ácido nítrico e ácido hidroclorídrico. Em outra parte do estudo 36 parafusos, foram submetidos a testes de tensão para determinar a resistência à fratura. Os sítios de fratura foram analisados através de microscopia eletrônica de varredura, para identificar defeitos que pudessem levar a falhas desses parafusos. Os resultados das análises microscópicas não revelaram defeitos significativos nos parafusos examinados. Diferenças foram encontradas na microestrutura, microdureza, composição da liga, e valores de fratura a carga, de ambos fabricantes. Características metalúrgicas diferentes e diferenças no processo de fabricação foram encontradas nos parafusos. Os valores de fratura foram de $850 \mathrm{~N}$ a $1093 \mathrm{~N}$. Uma diferença significante foi encontrada nos valores médios de fratura de diferentes lotes nos parafusos 3i. A fratura dúctil foi a condição de falha dos parafusos. A partir destes dados os autores concluíram que estas diferenças podem afetar os resultados clínicos quando estes parafusos são utilizados.

TAN; NICHOLLS ${ }^{107}$, neste mesmo ano, afirmaram que uma ótima précarga no parafuso de retenção de ouro é necessária para manter a estabilidade da união pilar/cilindro de ouro; pelo que mediram a condição de pré-carga obtida no parafuso de ouro em três sistemas de aplicação de torque. Dispositivos de torques manuais, controladores de torque eletrônico e aplicação através de chaves de torque foram comparados. Cinco implantes (Nobel Biocare) foram fixados com resina acrílica numa mandíbula edêntula. Nestes, pilares "standards" de $4 \mathrm{~mm}$ foram fixados aos implantes utilizando parafusos com um torque de 20Ncm. Em cada pilar três Strain Gauge foram fixados para obter as medidas através de um computador. No pilar um cilindro de ouro foi utilizado e um parafuso de ouro com cabeça plana foi testado aplicando-se $10 \mathrm{Ncm}$ de torque; 
utilizando-se três dispositivos de torques manuais (Nobel Biocare), quatro controladores de torques eletrônicos (Nobel Biocare), e três operadores aplicaram um torque manual. Os resultados mostraram que os dispositivos de aplicação de torque manual tiveram uma variação significativa na pré-carga induzida sobre o parafuso de ouro, média de 291,2N; controladores de torque eletrônico produziram média de $384,3 \mathrm{~N}$; e os diferentes operadores produziram média de 140,8N. Os controladores de torque eletrônicos produziram uma maior pré-carga que os outros dos sistemas de torque testados, porém os autores sugerem uma recalibração destes dispositivos em intervalos de tempo regulares, para assegurar um ótimo resultado. A média de pré-carga produzida pelos dispositivos de torque manuais foi a mais próxima da quantidade de pré-carga teoricamente recomendada nestes parafusos 300N. O uso de chaves manuais para aplicação do torque produziu uma pré-carga insuficiente ao parafuso de ouro, sendo inconsistente entre os diferentes operadores. Os autores acreditam também, que quando o cilindro de ouro é submetido aos diferentes processos de confecção da prótese, fundição e polimento; a pré-carga é prejudicada. 
PROPOSIÇÃO 


\section{3- Proposição}

Considerando a necessidade da determinação de padrões que possibilitem análise comparativa, a fim de avaliar a adaptação vertical entre componentes protéticos para implante tipo esteticone/e cilindros pré-usinados, antes e após a sobrefundição, com diferentes condições de aparafusamento em condição de prótese unitária, o presente trabalho propõe-se a avaliar:

1- A adaptação vertical da interface intermediário tipo esteticone/cilindro usinado industrialmente antes e após a sobrefundição nas seguintes condições:

A- Cilindro de ouro sobrefundido em liga de PdAg;

B- Cilindro de $\mathrm{NiCr}$ sobrefundido em liga de NiCr.

2- O papel do parafuso de fixação de ouro, em relação à condição adaptação vertical dos cilindros, variando a quantidade de torque aplicado: 10 e $20 \mathrm{Ncm}$.

3- O papel do parafuso de fixação de titânio, em relação à condição de adaptação vertical dos cilindros, variando a quantidade de torque aplicado: 10 e $20 \mathrm{Ncm}$.

4- A possível correlação entre as variáveis: tipo de liga dos cilindros, tipo de liga para sobrefundição, adaptação da interface em relação aos parafusos de fixação decorrente da condição de torque. 
MATERIAL E MÉTODOS 


\section{4- Material e Métodos}

\section{1- Confecção do modelo mestre}

Para realização dos testes, foi confeccionada por um torneiro mecânico especializado uma base sextavada em latão com as seguintes características: $2 \mathrm{~cm}$ de altura e $2 \mathrm{~cm}$ de diâmetro, em cujo centro foram feitas roscas, de modo que um implante com hexágono externo de comprimento $10 \mathrm{~mm}$ e 3,75mm de diâmetro, código 517710 (Conexão Sistemas de Prótese - São Paulo - SPBrasil), fosse rosqueado (Figura 4.1.1, 4.1.2.), tendo-se o cuidado de se manter exposto o hexágono, e apresentando como limite final visível a base de assentamento do implante. Sobre o implante, foi acoplado e parafusado um intermediário tipo esteticone, com cinta metálica de 2mm, código 022022 (Conexão Sistemas de Prótese - São Paulo - SP - Brasil), com um torque mecânico de $20 \mathrm{Ncm}$, executado pelo controlador de torque (NobelBiocare Torque Controler ${ }^{\mathrm{TM}}$, Gotemburgo, Suécia) (Figura 4.1.3). 


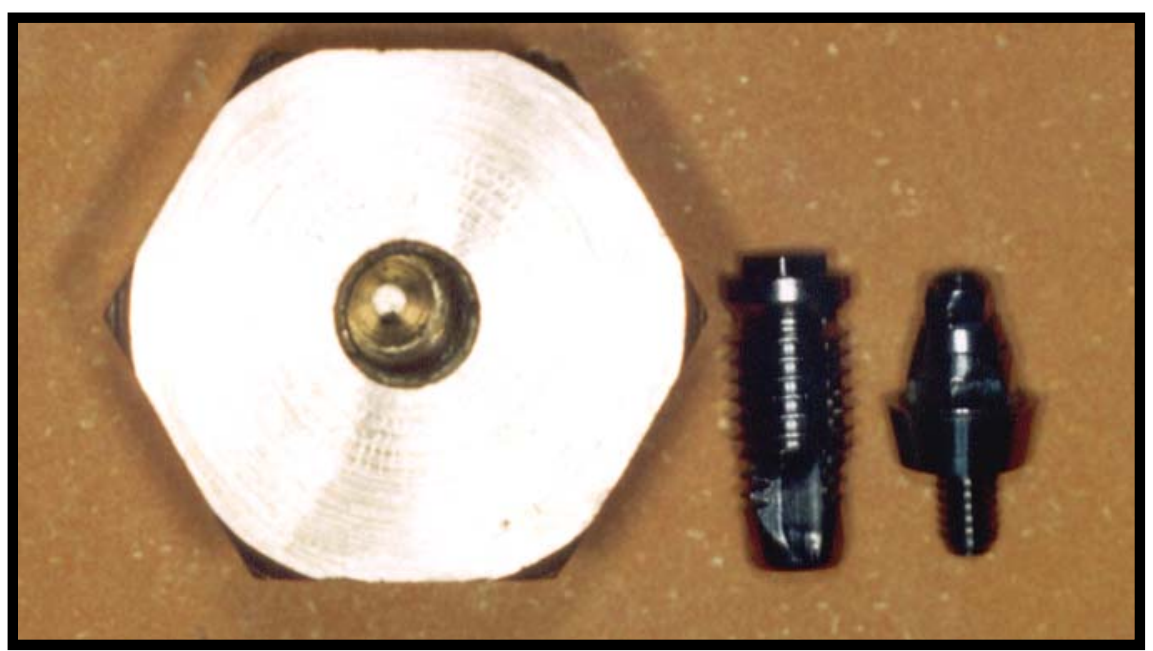

Figura 4.1.1: Base sextavada, implante e intermediário.

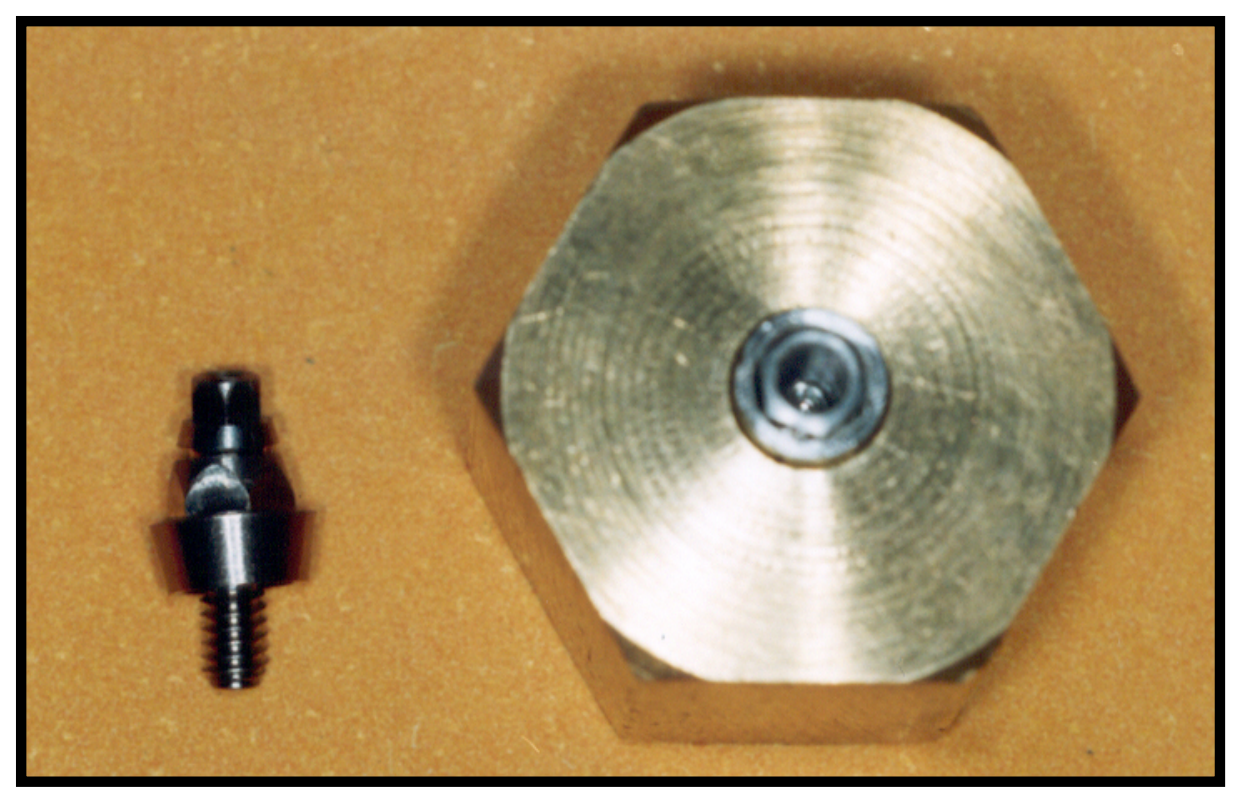

Figura 4.1.2: Base sextavada, implante instalado no orifício central e intermediário. 


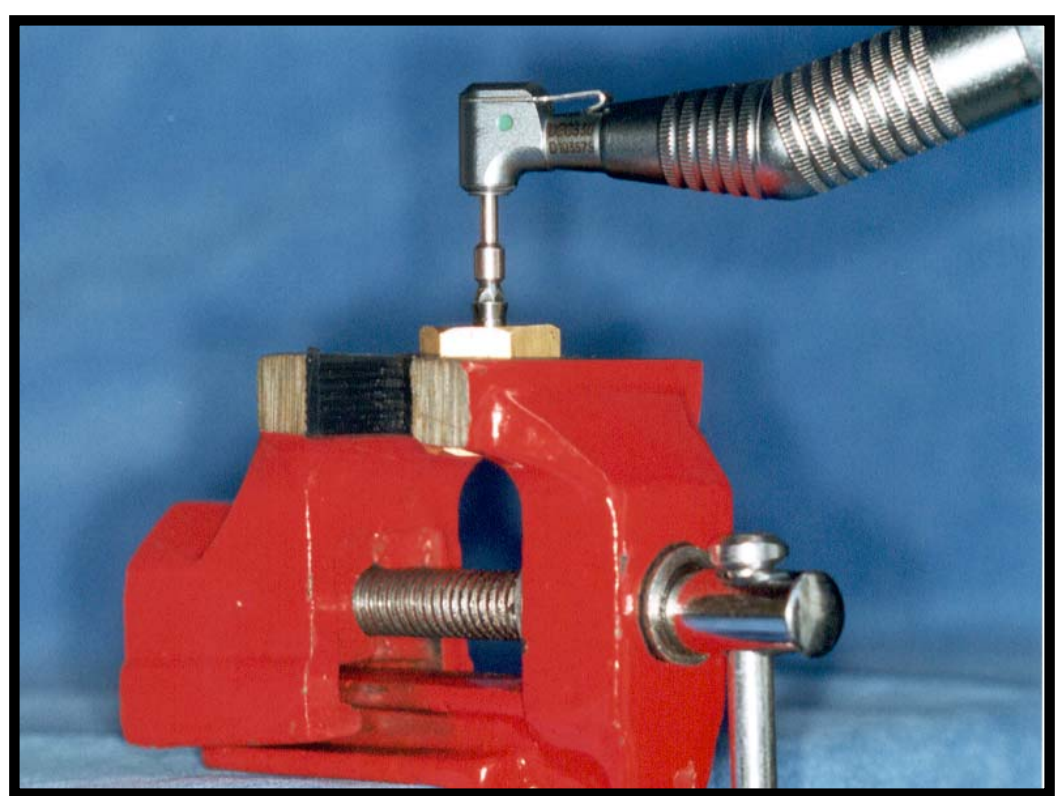

Figura 4.1.3: Instalação do intermediário à base através do Controlador de torque (Nobel Biocare).

\section{4-2: Divisão dos corpos de prova}

Este trabalho foi dividido em dois grupos para realização da análise estatística e para avaliação da adaptação da interface entre intermediário tipo esteticone/e cilindros, como mostra a tabela 4.2.1: 
Tabela 4.2.1: Divisão dos grupos para avaliação da interface vertical.

\begin{tabular}{|c|c|c|c|c|c|}
\hline & & & Quantidade & Fabricante & Código \\
\hline \multirow{3}{*}{$\begin{array}{l}\bar{O} \\
\frac{0}{\partial} \\
\text { 品 }\end{array}$} & $\begin{array}{l}\text { Cilindro pré- } \\
\text { usinado }\end{array}$ & $\begin{array}{c}\text { Ouro tipo IV com } \\
\text { A/R }\end{array}$ & 8 & $\begin{array}{c}\text { Conexão } \\
\text { Brasil }\end{array}$ & 106002 \\
\hline & \multirow{2}{*}{$\begin{array}{l}\text { Parafusos de } \\
\text { fixação com } \\
\text { hexágono }\end{array}$} & Ouro & 8 & $\begin{array}{c}\text { Conexão } \\
\text { Brasil }\end{array}$ & 011002 \\
\hline & & Titânio & 8 & $\begin{array}{c}\text { Conexão } \\
\text { Brasil }\end{array}$ & 011004 \\
\hline \multirow{3}{*}{$\begin{array}{l}\overline{\bar{O}} \\
\bar{O} \\
\frac{0}{\partial} \\
\text { 品 }\end{array}$} & $\begin{array}{l}\text { Cilindro pré- } \\
\text { usinado }\end{array}$ & $\mathrm{NiCr} \operatorname{com} \mathrm{A} / \mathrm{R}$ & 8 & $\begin{array}{l}\text { C.O.B.E. } \\
\text { Brasil }\end{array}$ & \\
\hline & Parafusos de & Ouro & 8 & $\begin{array}{l}\text { Conexão } \\
\text { Brasil }\end{array}$ & 011002 \\
\hline & hexágono & Titânio & 8 & $\begin{array}{c}\text { Conexão } \\
\text { Brasil }\end{array}$ & 011004 \\
\hline
\end{tabular}

Como exemplo da divisão dos grupos temos a Figura 4.2.1, mostrando um dos cilindros e parafusos de ouro e titânio com hexágono.

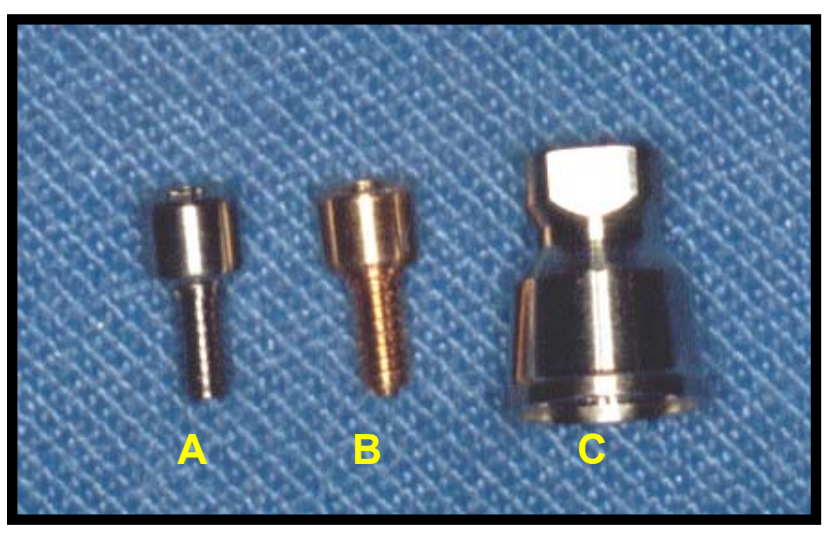

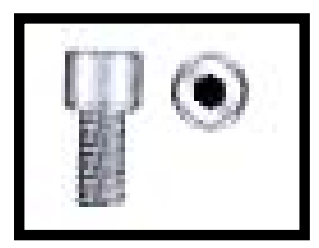

D

Figura 4.2.1: A- Parafuso de fixação da prótese em titânio, B- Parafuso de fixação da prótese em ouro, C- Cilindro de ouro e D- Visão oclusal do hexágono do parafuso de fixação. 


\section{3- Medida da adaptação vertical na interface entre intermediário/cilindros antes da sobrefundição.}

A análise dessa interface foi realizada com auxilio do microscópio óptico Mitutoyo TM- modelo 5050/JAPAN, código 176-811A, com aumento 150 vezes (ocular de 15x e objetiva de 10) e cabeçotes micrométricos código 164-162, com mostrador digital embutido e precisão de $1 \mu \mathrm{m}$ (Figura 4.3.1).

Os cilindros de todos os grupos foram assentados um de cada vez ao hexágono do intermediário e apertado primeiramente à $10 \mathrm{Ncm}$ pelo controlador de torque (Nobel Biocare-Torque Controler ${ }^{\mathrm{TM}}$-Gotemburgo-Suécia) (Figura 4.3.2) por um parafuso de fixação de ouro código 011002. A base era segura por uma morsa para evitar que esta não se movimentasse durante os torques (Figura 4.3.3), e levada para a leitura da desadaptação dessa interface (Figura 4.3.4). Após essa primeira leitura, o mesmo parafuso foi apertado a $20 \mathrm{Ncm}$, pelo mesmo controlador de torque, e foi feita a leitura novamente. Então, acionou-se o contratorque do mesmo controlador para a total remoção desse parafuso. Ainda mantendo o mesmo cilindro, empregou-se o parafuso de fixação de titânio código 011004 e o mesmo tipo de aperto e leitura foi realizado. Então, para cada, cilindro obtiveram-se dois parafusos, um de ouro e o outro de titânio, variando a quantidade de torque aplicada. Procedeu-se dessa maneira para todos os cilindros dos grupos I e II. 


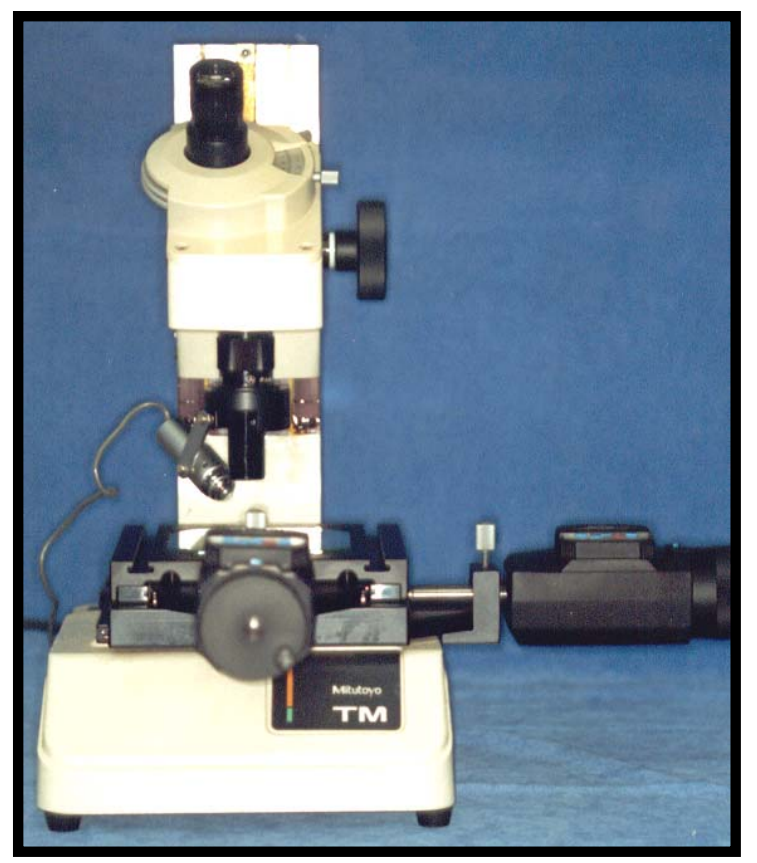

Figura 4.3.1: Microscópio óptico Mitutoyo, modelo 5050/Japan

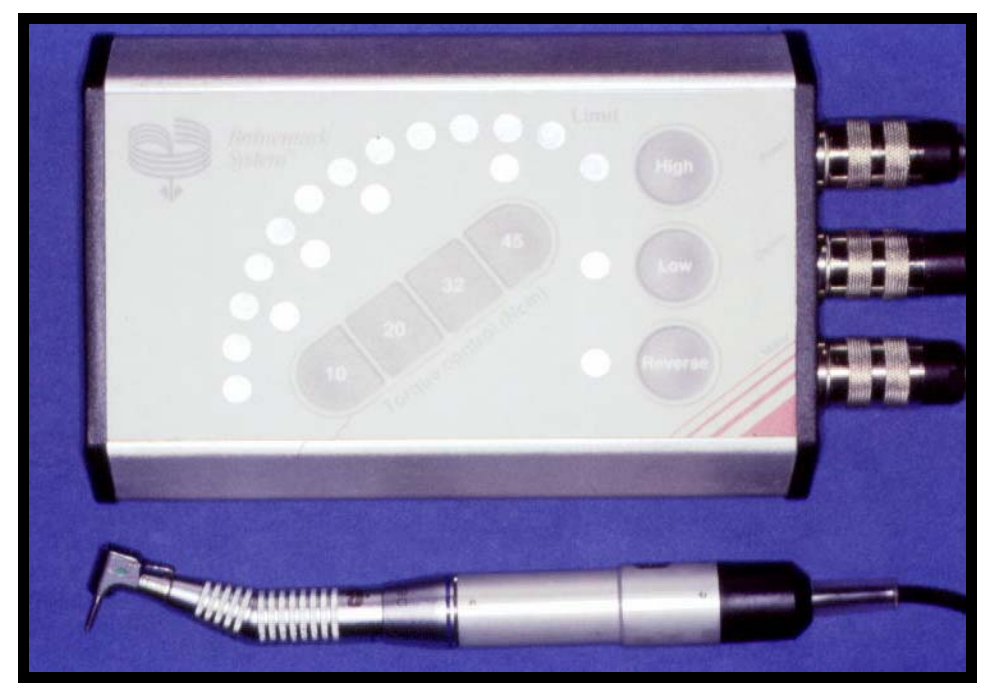

Figura 4.3.2: Controlador de torque (Nobel Biocare). 


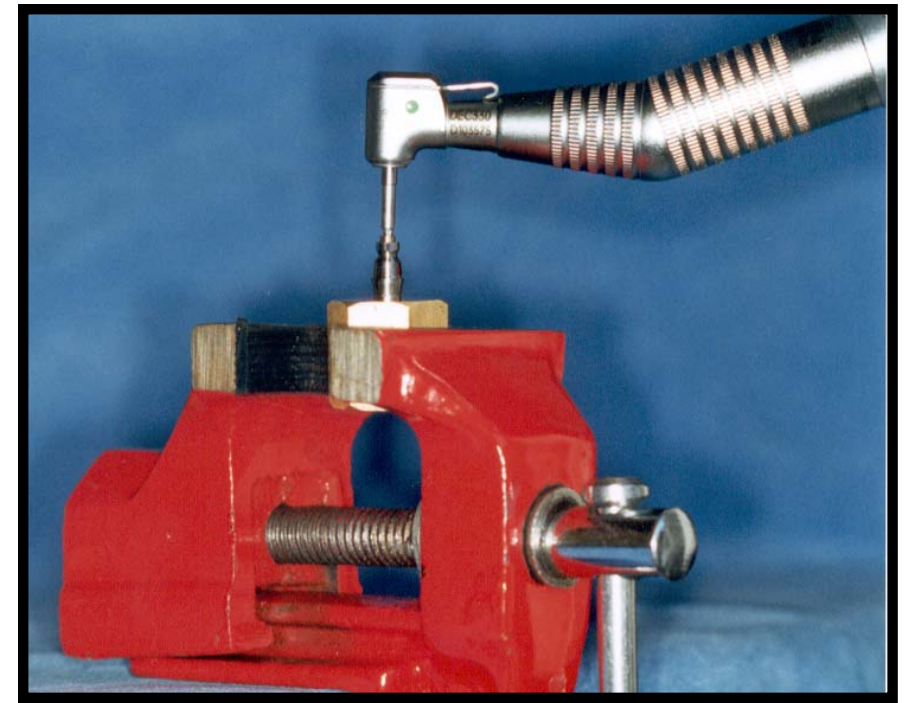

Figura 4.3.3: Exemplo da instalação de um cilindro ao intermediário através do torquímetro (Morsa adaptada à mesa para fixar o corpo de prova)

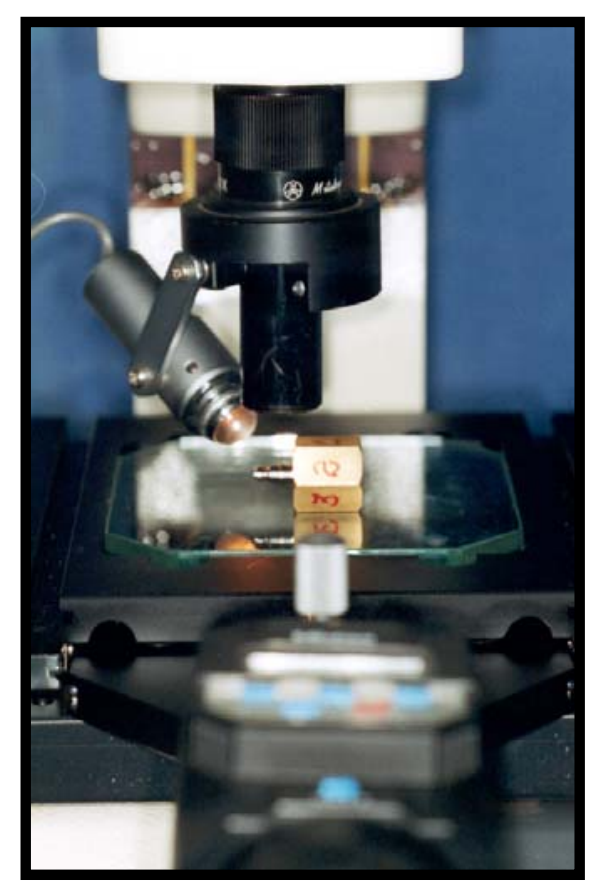

Figura 4.3.4: Leitura da adaptação vertical de um cilindro em microscópio óptico. 
Cada cilindro recebeu no seu exterior uma marca com um caneta para metal, vermelha, sendo que a base do corpo de prova também foi marcada. $A$ base, sextavada, foi enumerada de 1 a 6 , sendo que a face 1 coincidia com a mesma posição da marca do cilindro (Figura 4.3.5). Isso foi possível devido ao fato de serem anti-rotacionais. Esse espaço foi analisado de perfil, começando na face 1 , e assim sucessivamente até a 6 . As medidas eram executadas quando as interfaces se apresentavam paralelas e quando as linhas ordenada e abscissa do microscópio óptico definiam a posição de um ponto central entre o cilindro e o intermediário (Figura 4.3.6). Essas medidas eram expressas em micrometros.

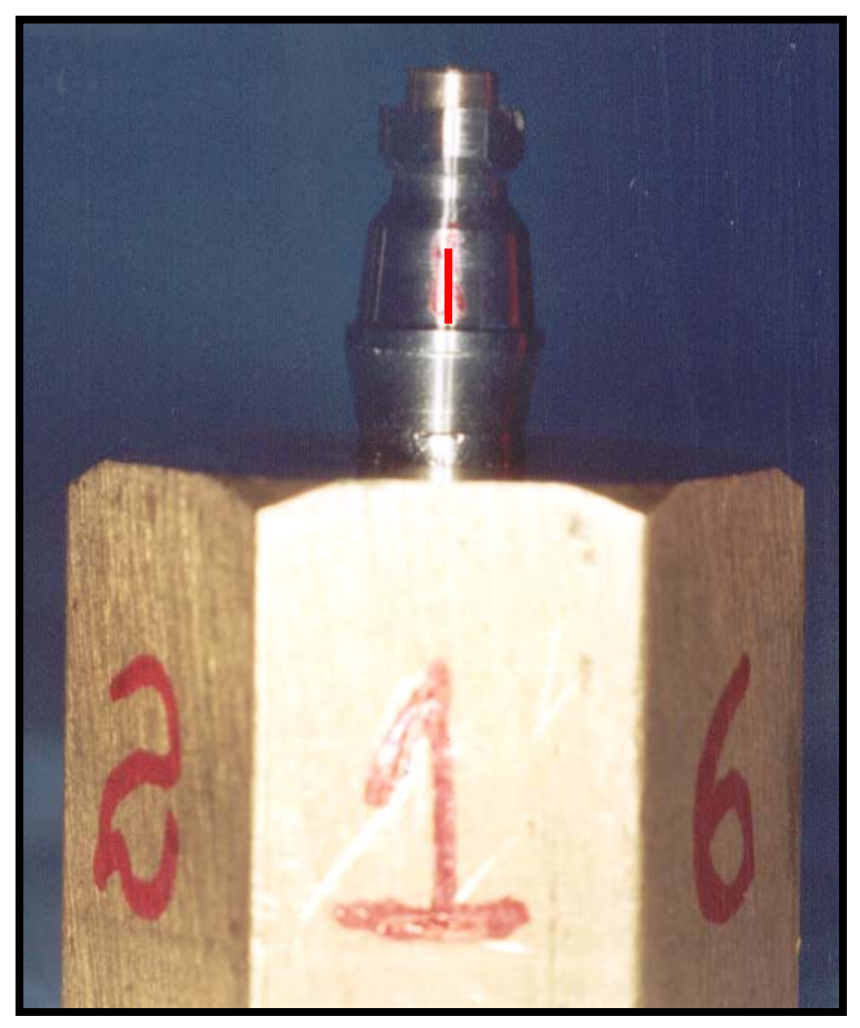

Figura 4.3.5: Base sextavada numerada com o cilindro em posição, também marcado. 


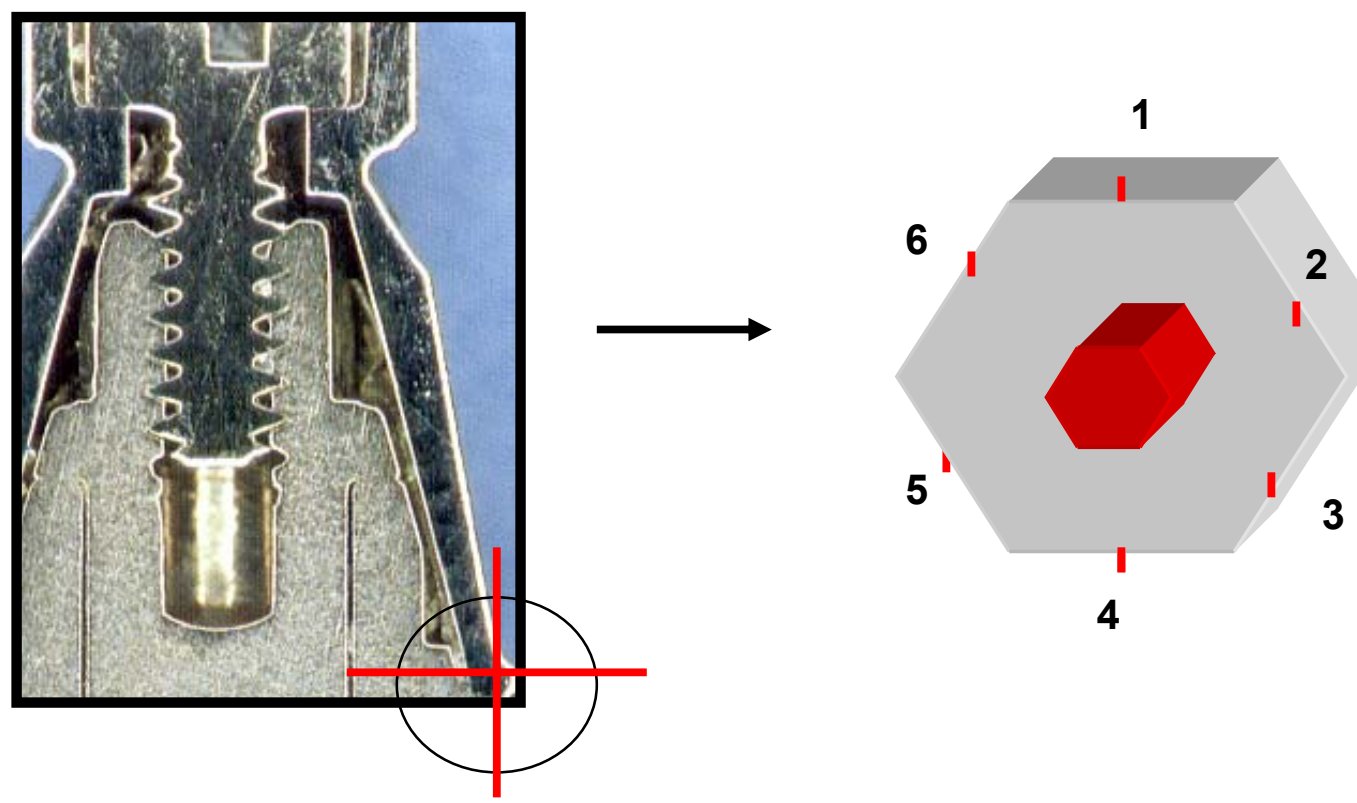

Figura 4.3.6: Corte esquemático e seqüência numérica das áreas onde eram feitas as medições entre intermediários e cilindros.

Cada face foi medida três vezes, em todos os 16 cilindros, num total de 48 medidas determinando, assim, uma média entre elas.

Considerou-se como desadaptação vertical a ocorrência de qualquer espaço existente na interface entre intermediário/cilindro visível ao microscópio.

Considerou-se como adaptação vertical quando era possível observar um contato íntimo entre as superfícies de assentamento do intermediário/cilindro. A essa ausência de espaço atribuiu-se o valor zero.

\section{4- Enceramento dos corpos de prova}

Os cilindros, agora chamados de corpos de prova, foram posicionados ao conjunto intermediário/implante (que estava sobre a base sextavada) e este foi transferido para a base cilíndrica (Figura 4.4.1), que serviu apenas para os 
processos de enceramento, inclusão e sobrefundição. Um cilindro escolhido aleatoriamente recebeu um enceramento (Kota-Indústria e Comércio-São PauloSP) na forma de pré-molar (Figura 4.4.2) o qual inicialmente serviu para a realização de uma matriz de silicone (Figura 4.4.3) para a confecção dos demais. Então, todos os cilindros foram esculpidos com o mesmo formato, para receber a sobrefundição, respeitando-se durante a escultura, que a face vestibular coincidisse com a face onde o cilindro foi marcado; e consequentemente, o lado 1 da base do corpo de prova. Por sua vez, cada cilindro foi apertado por um parafuso de trabalho protético código 167000 (Conexão Sistemas de Prótese-São Paulo-SP-Brasil) para dar estabilidade. Na base cilíndrica confeccionaram-se dois orifícios circulares e um na forma de $\mathrm{V}$ na face correspondente a vestibular, de forma que a matriz se encaixava perfeitamente nesta base. Na matriz, confeccionou-se um orifício em uma das suas extremidades, onde era gotejada cera liquefeita através de um conta-gotas, procedendo-se, assim ao enceramento de todos os outros corpos de prova. Em seguida, aguardava-se a total solidificação da cera para a matriz ser removida (Figura 4.4.4). A utilização da matriz objetivou a padronização dos corpos de prova. Uma vez concluído o enceramento estas eram cuidadosamente avaliadas e se removiam pequenos excessos de cera. 


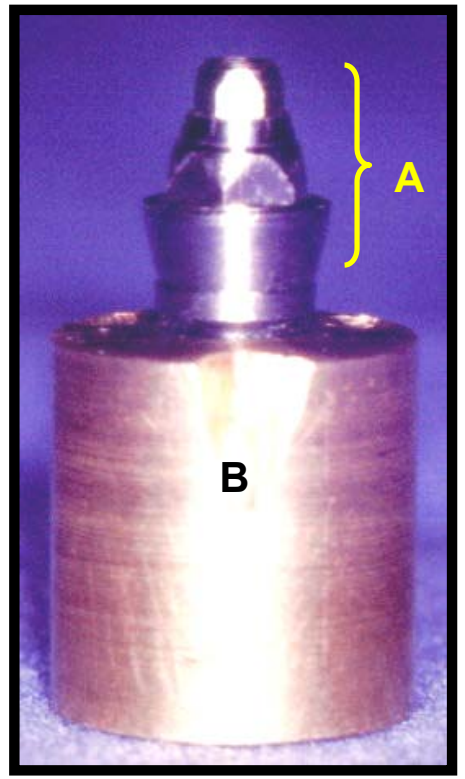

Figura 4.4.1: A- Conjunto esteticone/implante transferidos para, BBase utilizada na fase laboratorial.
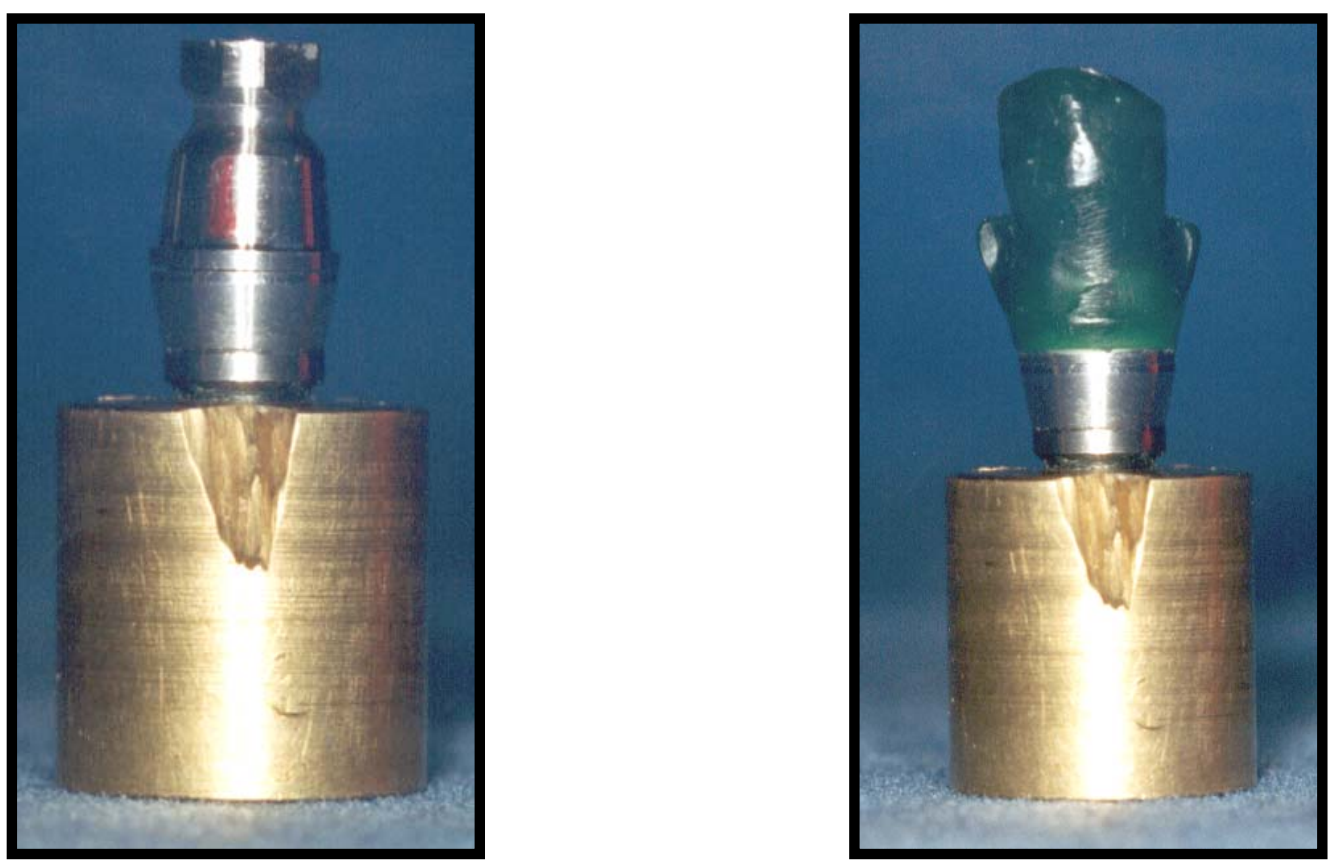

Figura 4.4.2: A- Cilindro em posição, B- Enceramento para a confecção da matriz 

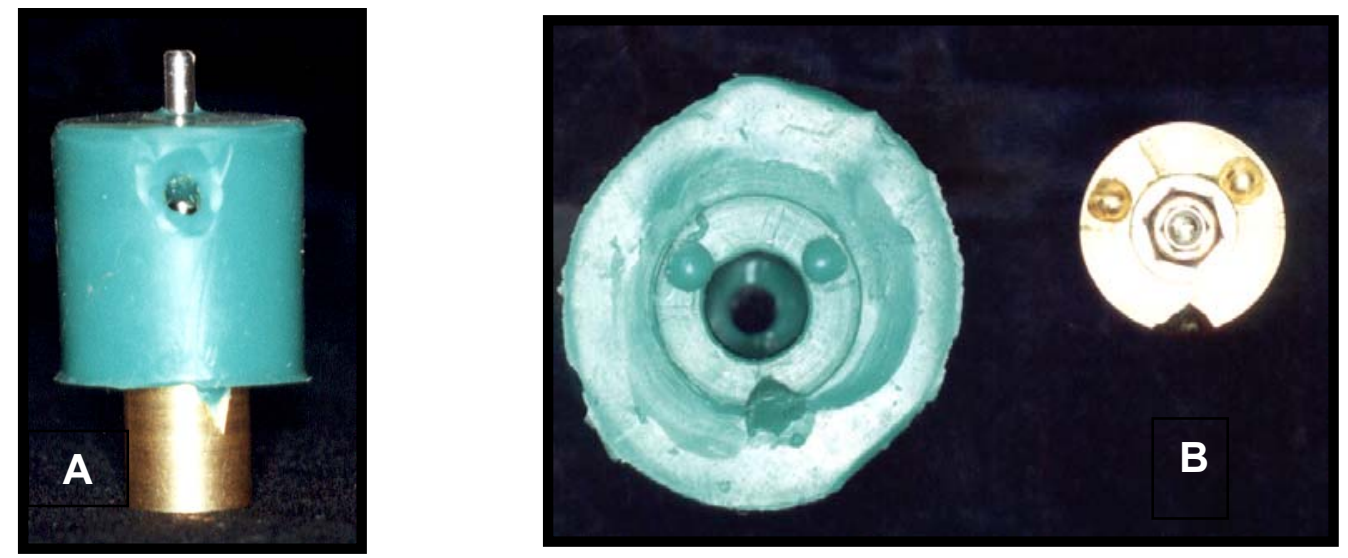

Figura 4.4.3: Matriz confeccionada. A- Matriz em posição na base cilíndrica e B- Visão oclusal da matriz em silicone e base.
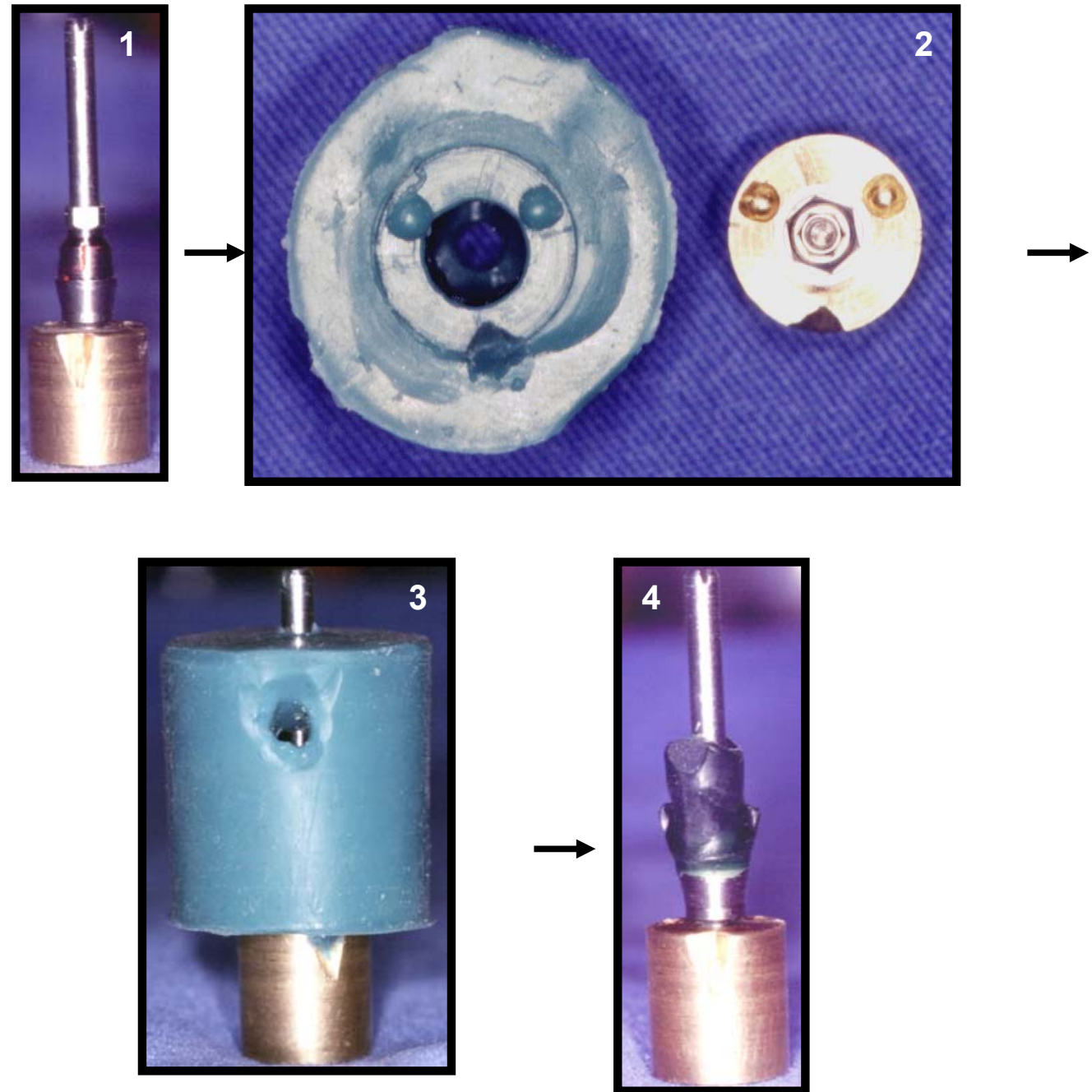

Figura 4.4.4: Seqüência da realização dos enceramnetos de todos os corpos de prova. 
Foram realizados 16 corpos de prova, sendo que os 8 cilindros de ouro tipo IV foram sobrefundidos com uma liga semi-nobre de paládio-prata (Proton Lacroix LTDA - Rio de Janeiro - Brasil), e os 8 cilindros de níquel-cromo foram sobrefundidos em níquel-cromo ( Vera - Bond II - Albadent - Califórnia - U.S.A.) (Figura 4.4.5).
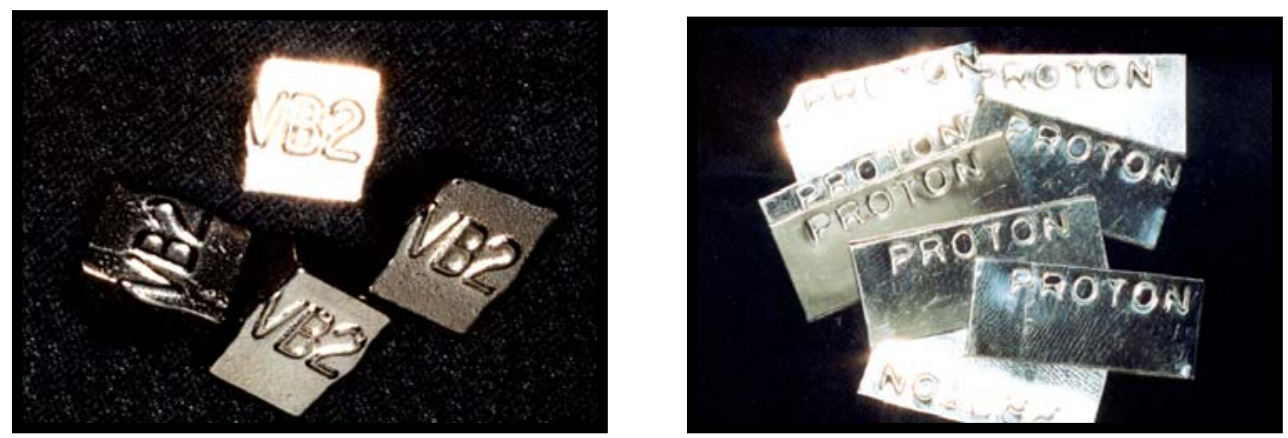

Figura 4.4.5: Ligas utilizadas (Vera Bond II e Proton).

\subsection{Inclusão dos corpos de prova}

Em uma base formadora de cadinho, foi adaptada uma barra do tipo Speedbar (ESBG 100-Phoenix Tech. Inc.) que é um sprue do tipo indireto, indicado para casos em que vários elementos serão incluídos em um mesmo anel (Figura 4.5.1). Incluíram-se em cada anel, 4 corpos de prova. Estes foram posicionados no sprue através de um fio de cera de $2 \mathrm{~mm}$ de espessura (Figura 4.5.2). 


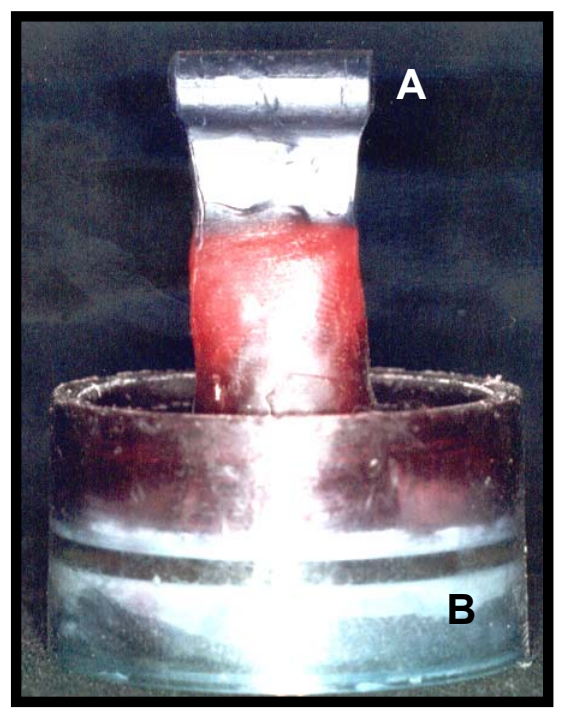

Figura 4.5.1: A-Sprue horizontal e B- base formadora de cadinho.
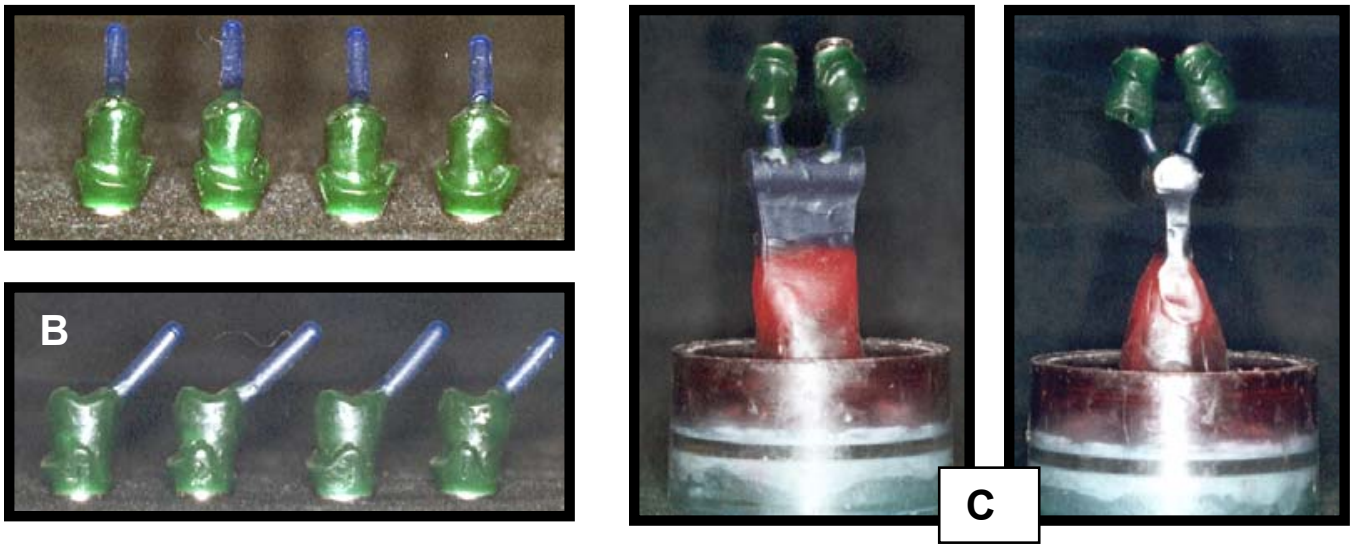

Figura 4.5.2: A- Corpos de prova encerados, B-Vista lateral dos corpos de prova encerados e C- Posicionamento dos corpos de prova no sprue antes da inclusão.

Aplicou-se um agente redutor de tensão superficial (Anti-bolhas-KotaIndústria e Comércio-São Paulo-SP), em toda as superfícies do padrão em cera, retirando-se os excessos com jatos intermitentes de ar. Após essas etapas um anel de silicone com capacidade para $90 \mathrm{gr}$ de revestimento foi adaptado à base formadora de cadinho (Figura 4.5.3). 


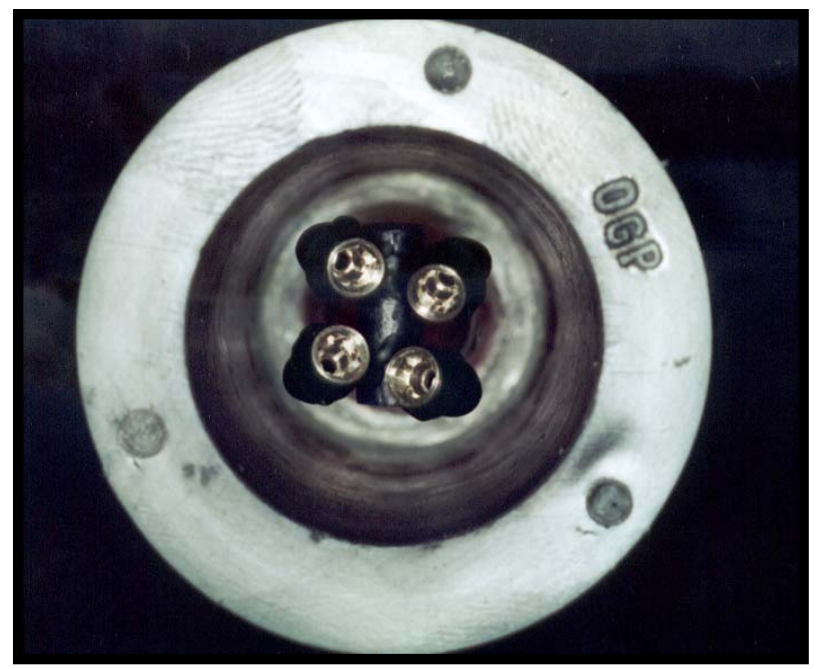

Figura 4.5.3: Anel de Silicone sobre a base formadora de cadinho, com os corpos de prova posicionados.

O revestimento utilizado foi do tipo aglutinado por fosfato de micropartículas (Talladium Micro-Fine 1700-Odontológica), o qual foi proporcionado de acordo com as especificações do fabricante dependendo do tipo de liga utilizada. A espatulação do revestimento foi realizada de acordo com a técnica do próprio fabricante, que consistiu em incorporar o pó ao líquido, espatular por aproximadamente 10 segundos e levar à espatulação mecânica (Vcuum Power Mixer Plus-Whip Mix Corporation-USA), por 40 segundos.

Os cilindros com enceramento, foram pincelados com o revestimento na porção interna de cada cilindro e, então, preencheu-se por completo o anel de silicone com o revestimento ainda sob vibração.

A inclusão foi realizada manualmente, com auxilio de vibração mecânica. Aguardou-se o tempo de presa do revestimento, de acordo com as especificações 
da empresa (18 minutos, a uma temperatura de $\pm 22^{\circ} \mathrm{C}$ ), antes de se prosseguir aos passos seguintes.

\section{6- Fundição dos corpos de prova}

Após a remoção da base formadora de cadinho e do anel de silicone, os corpos de prova obtidos na inclusão foram colocados no interior do forno (Radiance-Jelrus-USA), pré-aquecido a uma temperatura de $750^{\circ} \mathrm{C}$, em posição reta sobre uma base sulcada, para eliminação da cera e melhor ventilação do padrão de revestimento. O forno foi ajustado, então, a $930^{\circ} \mathrm{C}$ por mais meia hora.

O cadinho cerâmico, previamente aquecido, foi posicionado no braço da centrífuga para fundição, que foi ativada sempre com a mesma quantidade de voltas. A liga NiCr foi colocada no local apropriado e fundida da forma uniforme e gradual, através de um maçarico (RPM 247.5-Swiss Made), com proporções adequadas de propano/oxigênio. A obtenção do aspecto da liga em seu ponto de liquefação foi entre 1280 e $1330^{\circ} \mathrm{C}$ para a liga de $\mathrm{PdAg}$, e de 1350 à $1450^{\circ} \mathrm{C}$ para a liga de $\mathrm{NiCr}$, determinando assim o momento de liberar a trava da centrífuga a fim de que o metal fosse injetado no interior do molde. O mesmo procedeu-se para as duas ligas, variando apenas a temperatura de fusão.

O revestimento foi removido da parte interna dos corpos de prova com ácido hidroflorídrico a 45\%, e a parte externa recebeu jateamento de óxido com micro esferas de vidro o suficiente para remover todo o revestimento a uma distância de 5cm, por 10 segundos, não atingindo a superfície interna dos corpos de prova protegidas por análogos de abutments de esteticone parafusado a cada cilindro. 
Então, os corpos de prova já fundidos e limpos (Figura 4.6.1) receberam averiguação com lupa Lactona $4 \mathrm{X}$ de aumento, para identificação de possíveis bolhas ou irregularidades, as quais poderiam descartar os corpos de prova.

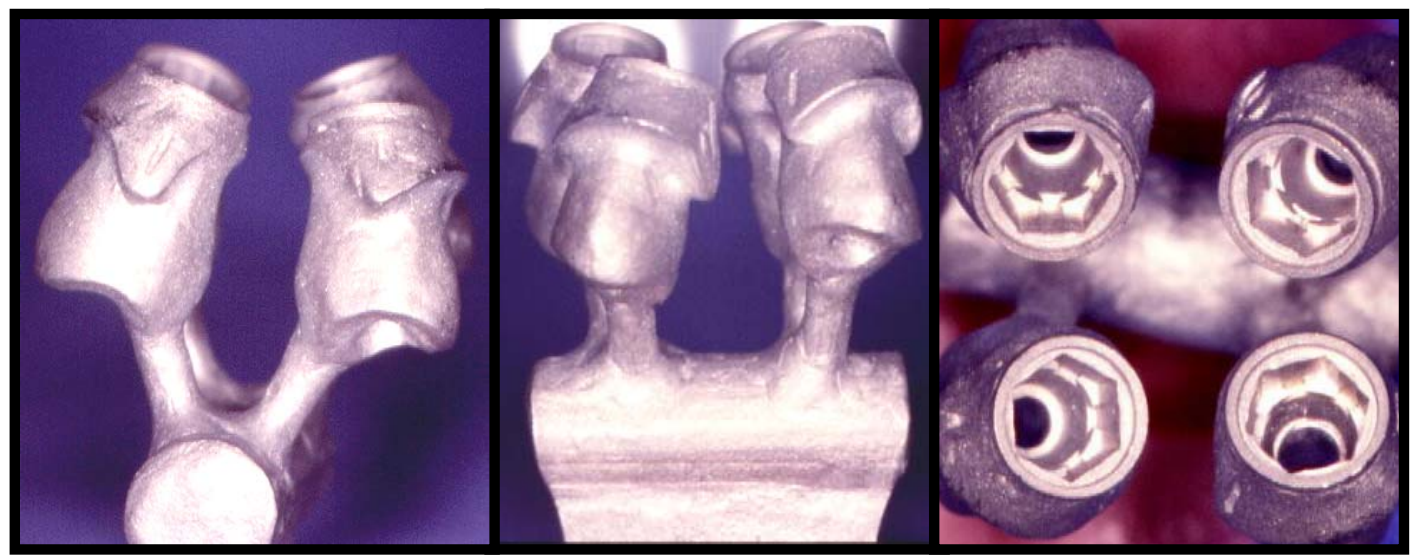

Figura 4.6.1: Corpos de prova após a sobrefundição, jateados e limpos antes de serem separados do sprue e canais de alimentação.

O conjunto intermediário/ implante retornou para a base sextavada, agora com os cilindros sobrefundidos, para a realização das novas leituras.

\section{7- Medida da adaptação vertical na interface entre}

\section{intermediário/cilindros após a sobrefundição}

Após a sobrefundição, os corpos de prova foram avaliados novamente na interface entre intermediário/cilindros com auxilio do mesmo microscópio óptico citado anteriormente, variando-se o torque dos parafusos de retenção e o tipo da liga destes parafusos (Figura 4.7.1). 


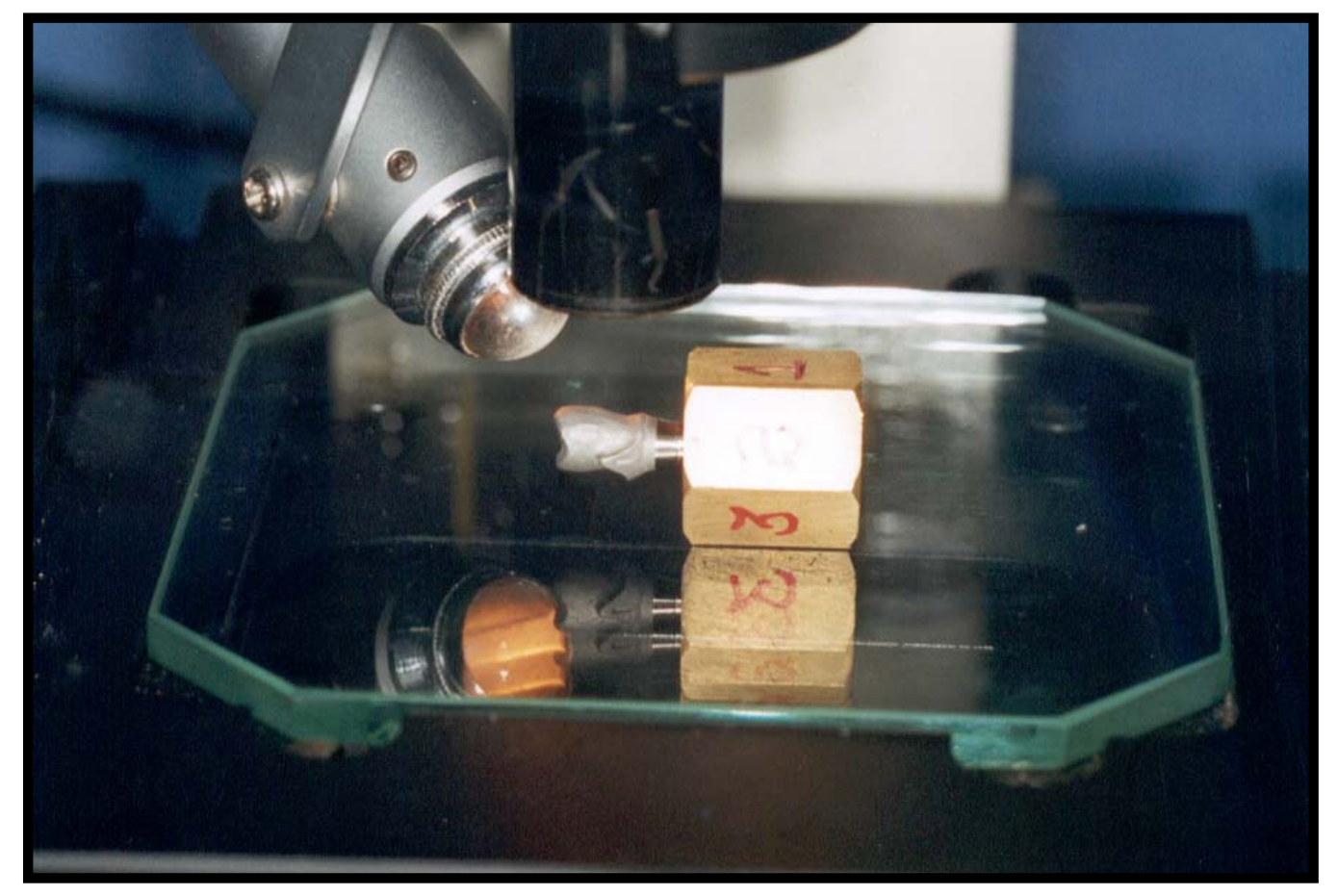

Figura 4.7.1: Corpo de prova após a sobrefundição, adaptado novamente ao intermediário na base sextavada e levado ao microscópio óptico para a realização das segundas leituras. 
Resultados 


\section{5- Resultados}

A Tabela 1 mostra a média e o desvio-padrão da adaptação vertical dos cilindros da liga $\mathrm{NiCr}$ e de ouro, antes e após as sobrefundições com liga de $\mathrm{NiCr}$ e PdAg, com torque nos parafusos de fixação hexagonal de 10 e $20 \mathrm{Ncm}$, expressos em micrometros.

Antes da realização das sobrefundições, a média da adaptação vertical foi menor para os cilindros de $\mathrm{NiCr}$ com torque de $20 \mathrm{Ncm}$. Após as sobrefundições, a média da adaptação vertical foi menor para os cilindros de ouro com torque de $20 \mathrm{Ncm}$.

Após as sobrefundições, os valores da adaptação vertical aumentaram para os cilindros de $\mathrm{NiCr}(10$ e $20 \mathrm{Ncm})$ e diminuíram para os cilindros de ouro (10 e $20 \mathrm{Ncm})$.

Tabela 1: Média e desvio-padrão da adaptação vertical das amostras de $\mathrm{NiCr}$ e Ouro, com parafuso de ouro e torques de 10 e $20 \mathrm{Ncm}$, antes e após as sobrefundições.

\begin{tabular}{cccc}
\hline & Antes & Após & Número \\
\hline NiCr 10 & $14,02 \pm 5,63$ & $20,93 \pm 7,10$ & 8 \\
NiCr 20 & $10,95 \pm 5,68$ & $15,77 \pm 4,72$ & 8 \\
Ouro 10 & $14,41 \pm 3,84$ & $11,79 \pm 4,06$ & 8 \\
Ouro 20 & $12,26 \pm 3,69$ & $9,59 \pm 3,25$ & 8 \\
\hline
\end{tabular}

A Tabela 2 mostra a média e o desvio-padrão dos cilindros de $\mathrm{NiCr}$ e ouro, antes e após as sobrefundições com liga de NiCr e PdAg, com torque de 10 e 20Ncm, quando da utilização do parafuso de titânio, em micrometros. 
Antes da sobrefundição, a média de adaptação vertical foi menor para os cilindros de $\mathrm{NiCr}$ com $20 \mathrm{Ncm}$ de torque. Novamente, após as sobrefundições, a média de adaptação vertical foi maior para os cilindros de $\mathrm{NiCr}$ e menor para os cilindros de ouro.

Tabela 2: Média e desvio-padrão da adaptação vertical das amostras dos cilindros de $\mathbf{N i C r}$ e Ouro, com parafuso de titânio e torques de 10 e $20 \mathrm{Ncm}$, antes e após as sobrefundições.

\begin{tabular}{cccc}
\hline & Antes & Após & Número \\
\hline NiCr 10 & $15,79 \pm 5,87$ & $21,46 \pm 7,27$ & 8 \\
NiCr 20 & $12,20 \pm 5,19$ & $17,90 \pm 7,06$ & 8 \\
Ouro 10 & $17,26 \pm 5,79$ & $11,59 \pm 4,03$ & 8 \\
Ouro 20 & $14,99 \pm 5,25$ & $9,41 \pm 3,72$ & 8 \\
\hline
\end{tabular}

Gráfico 5.1: Representação gráfica das médias e desvio padrão da adaptação vertical, dos cilindros de ouro e $\mathrm{NiCr}$ antes e após a sobrefundição e troque de 10 e $20 \mathrm{Ncm}$.

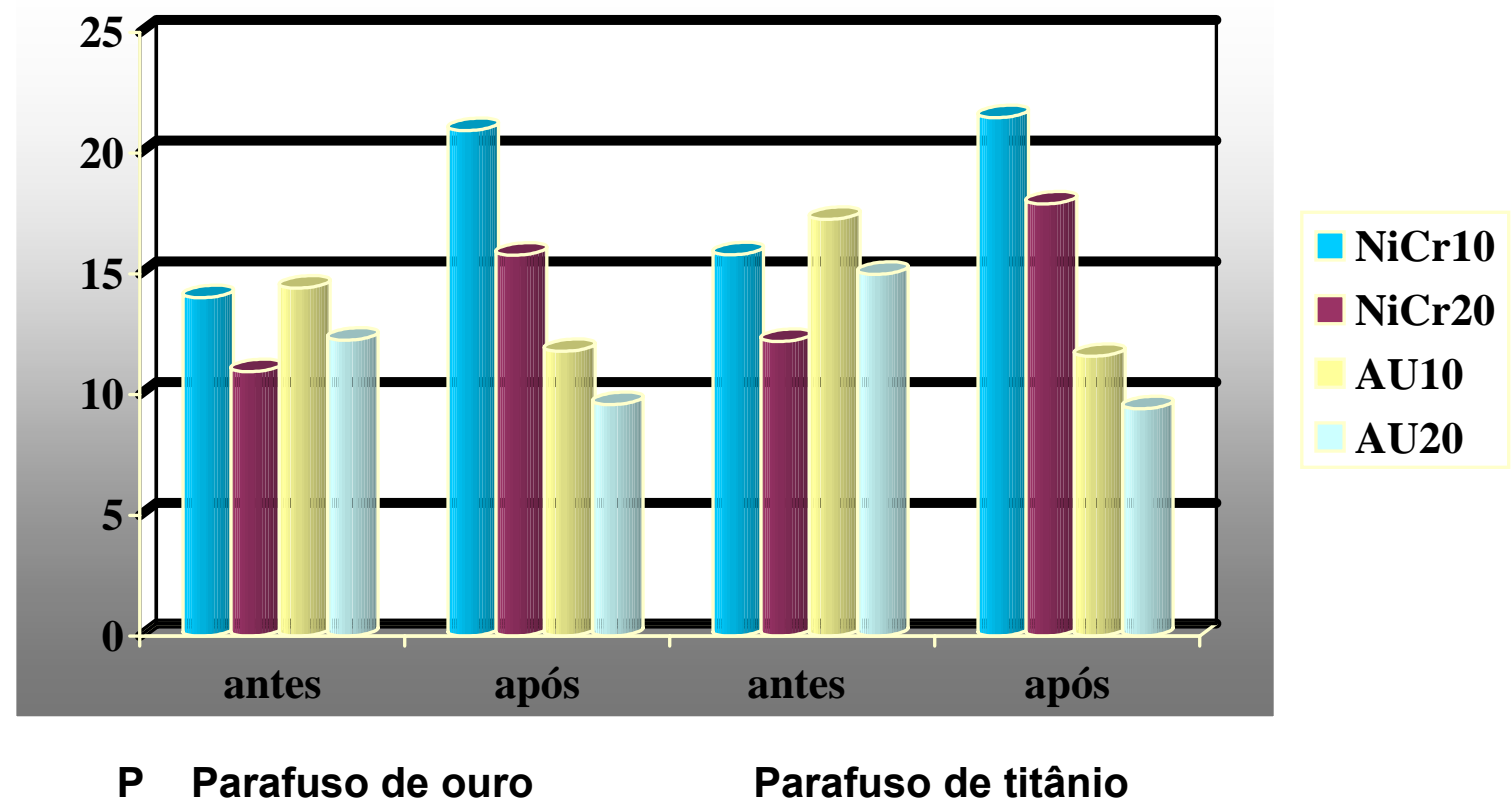


Para comparação da adaptação vertical, antes e após as sobrefundições foi utilizado teste não paramétrico de Wilcoxon, com nível de significância de 5\%, onde foram detectadas diferenças estatisticamente significantes observadas na tabela 3.

Tabela 3: Comparação entre os valores da adaptação vertical, antes e após as sobrefundições, com utilização do parafuso de ouro.

\begin{tabular}{cccc}
\hline Comparação & Antes & Após & Interpretação \\
\hline NiCr 10 (antes e após) & 0,005 & $-2,52$ & Significativa \\
NiCr 20 (antes e após) & 0,010 & $-2,10$ & Significativa \\
Ouro 10 (antes e após) & 0,86 & 1,12 & Não significativa \\
Ouro 20 (antes e após) & 0,91 & 1,40 & Não significativa \\
\hline
\end{tabular}

Para comparação da adaptação vertical, antes e após as sobrefundições foi utilizado teste não paramétrico de Wilcoxon, com nível de significância de 5\%, onde foram detectadas diferenças estatisticamente significantes, como observads na Tabela 4.

Tabela 4: Comparação entre os valores da adaptação vertical, antes e após as sobrefundições, com utilização do parafuso de titânio.

\begin{tabular}{cccc}
\hline Comparação & Antes & Após & Interpretação \\
\hline NiCr 10 (antes e após) & 0,03 & $-1,82$ & Significativa \\
NiCr 20 (antes e após) & 0,03 & $-1,82$ & Significativa \\
Ouro 10 (antes e após) & 0,96 & 1,82 & Não significativa \\
Ouro 20 (antes e após) & 0,97 & 1,96 & Não significativa \\
\hline
\end{tabular}

Com relação aos valores obtidos quando da variação do material do parafuso (ouro ou titânio), uma análise das Tabelas 1 e 3 mostra que as 
sobrefundições nos cilindros NiCr com parafuso de ouro e de titânio possuem diferenças semelhantes de adaptação vertical (torques de 10 e 20Ncm).

Para os cilindros de ouro, a diferença de adaptação é igual tanto para o parafuso de ouro quanto para o parafuso de titânio (nos torques de 10 e 20Ncm), sendo mais decisivo o material empregado para a sobrefundição (ouro) e não o tipo de parafuso.

Tabela 5: Diferenças entre as médias da adaptação vertical, antes e após as sobrefundições, com variação do material do parafuso, quantidade de torque e tipo de liga utilizada, em micrometros.

\begin{tabular}{|c|c|c|c|c|}
\hline $\begin{array}{l}\text { Cilindro } \\
\text { Parafuso }\end{array}$ & $\begin{array}{c}\mathrm{NiCr} 10 \\
\text { (antes e após) }\end{array}$ & $\begin{array}{c}\mathrm{NiCr} 20 \\
\text { (antes e após) }\end{array}$ & $\begin{array}{c}\text { Ouro } 10 \\
\text { (antes e após) }\end{array}$ & $\begin{array}{c}\text { Ouro20 } \\
\text { (antes e após) }\end{array}$ \\
\hline Ouro & 6,91 & 4,82 & $-2,62$ & $-2,67$ \\
\hline Titânio & 5,67 & 5,70 & $-5,67$ & $-5,58$ \\
\hline
\end{tabular}

Gráfico 5.2: Representação gráfica das médias e desvio padrão da adaptação vertical, antes e após a sobrefundição, com variação da liga dos parafusos de fixação, quantidade de torque e cilindro utilizado.

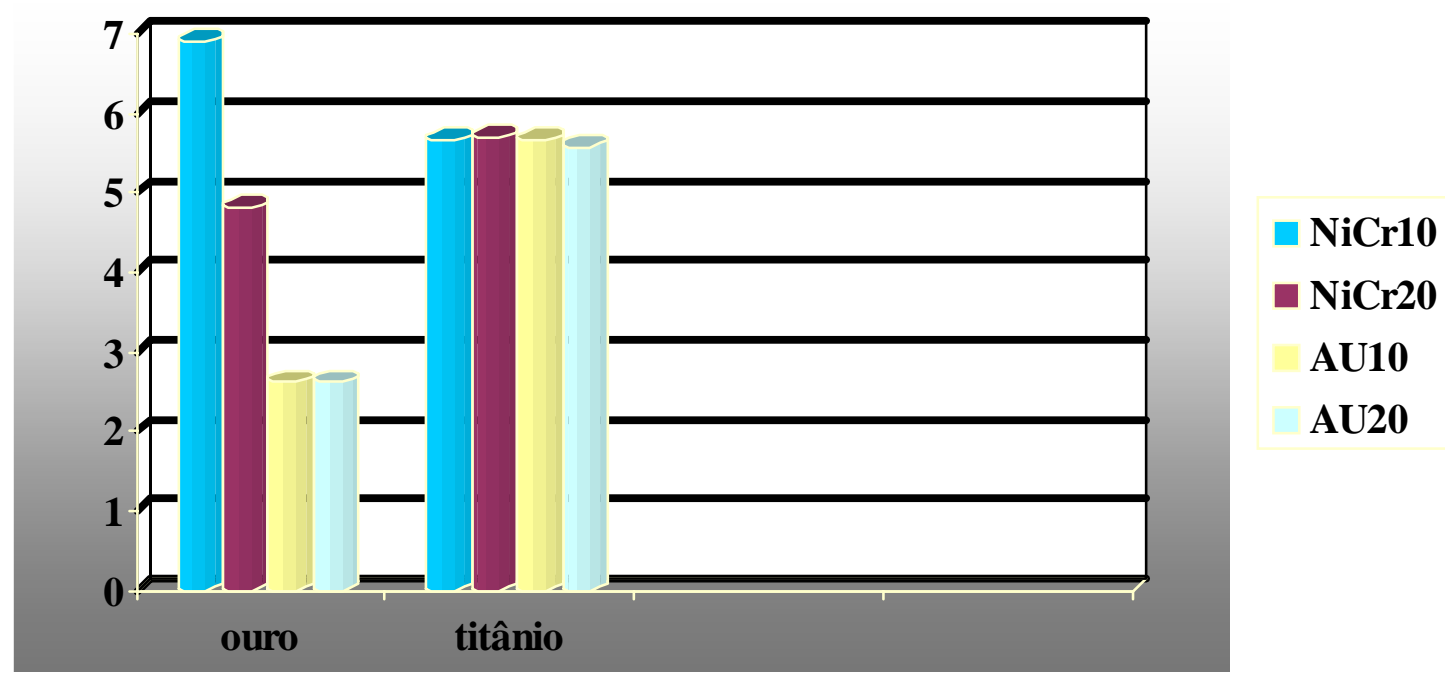


DIscussão 


\section{6- Discussão:}

Em acompanhamentos clínicos longitudinais, o uso de implantes osseointegrados como suporte de próteses unitárias é um procedimento clínico viável, onde comprovados índices de sucesso são relatados ${ }^{3,5,32,35,44,51,52,63,71,87}$. Com freqüência são desenvolvidos novos implantes e componentes pelos fabricantes, no intuito de obter resultados que garantam melhoras na estética e na função das restaurações unitárias, que são o grande desafio do cirurgião-dentista reabilitador.

Falhas protéticas são comuns nesse tipo de restauração, principalmente no referente à estabilidade do parafuso de fixação que une o pilar ao implante, ou do parafuso que une a prótese ao pilar. Altas percentagens de falhas são reportadas nos estudos de acompanhamento clínico ${ }^{3,5,10,32,44,51,86,95}$. Pesquisas clínicas e laboratoriais são realizadas com o objetivo de se estabelecerem as principais causas desse tipo de falhas, de forma que possam proporcionar dados que permitam o desenvolvimento de componentes que levem à diminuição ou à eliminação desse problema.

As próteses unitárias sobre implantes são as mais difíceis de serem respostas devido à sua biomecânica complicada quando se trata da substituição de elementos dentários nas áreas de pré-molares e molares. Isso porque, mesmo áreas, as forças oclusais são maiores e uma incorreta oclusão ${ }^{62}$, pode levar ao aumento das tensões nos componentes e osso, tornando a união mais susceptível a falha ${ }^{5}$. A cúspide com pouca inclinação leva componentes de forças laterais pequenos e a uma maior relação de contato cêntrico, o que terá como 
conseqüência uma maior concentração de forças axiais, tornando favorável a distribuição das cargas nos componentes ${ }^{115}$.

O comportamento biomecânico das restaurações unitárias, no setor posterior, e os altos índices de falhas na estabilidade da união implante/pilar, principalmente na área de molar ${ }^{5}$, levou pesquisadores a sugerirem a utilização de implantes de largo diâmetro ${ }^{25}$, ou uso de sistemas de implantes com conexões que permitam estabelecer restaurações mais estáveis ${ }^{63,103,104}$ e, consequentemente, determinar um maior índice de sucesso.

A conexão hexagonal externa, que inicialmente foi desenvolvida para permitir a instalação do implante no leito cirúrgico, tornou-se fundamental para restauração unitária já que permitiu desenvolver um mecanismo de estabilidade anti-rotacional entre o implante e a restauração. Esse aspecto também é importante na precisão da transferência da posição para o modelo de trabalho e a confecção de uma adequada relação de contato com os dentes adjacentes. Além disso o hexágono torna a interface implante/ pilar mais resistente ${ }^{25}$.

A adaptação e precisão dos componentes também têm sido relatadas como um aspecto importante na estabilidade da união implante/pilar/cilindro de ouro $^{12,15,20,22,29,33,42,50,61,111}$. Variações na consistência da fabricação dos componentes podem levar à implicações clínicas de diferentes magnitudes. O diâmetro da base do implante requer um tamanho consistente com mínimas variações, com o intermediário e cilindro, já que diferenças podem resultar na formação de um espaço ou fendas, o que possivelmente provocará uma invasão bacteriana, acúmulo de placa e uma resposta tissular adversa ${ }^{41,50}$.

Análise da adaptação vertical entre intermediários tipo esteticone/ e cilindros, sem sobrefundição, foi primeiramente observada neste estudo. É 
evidente que os sistemas de conexão estudados têm uma alta consistência dentro de cada um dos grupos, sendo que diferenças aceitáveis são encontradas. Esses sistemas de conexão foram utilizados para análise da adaptação vertical microscópica óptica, na interface intermediário/cilindro dos grupos estudados. Observou-se que existem irregularidades no contorno da interface cilindro/intermediário, sendo estas arredondadas ou biseladas na parte mais externa (Figuras 6.1 e 6.2, exemplos das interfaces avaliadas). Isso coincide com os relatos encontrados na literatura ${ }^{20,29,57}$. Apesar dessa condição poder ter alguma repercussão biológica, como a de dificultar a inspeção, a presença desta condição não significa a ausência de adaptação, sendo que a leitura foi realizada sem considerar o bisel gerado pelos componentes, o que daria uma falsa desadaptação. Assim, os valores obtidos representam o espaço vertical real da interface. Provavelmente essas alterações não tenham muito importância na estabilidade da interface, porém esse fator é importante, já no acúmulo de placa e aumento da atividade bacteriana nessas áreas podem ocorrer e provocar alterações gengivais. 


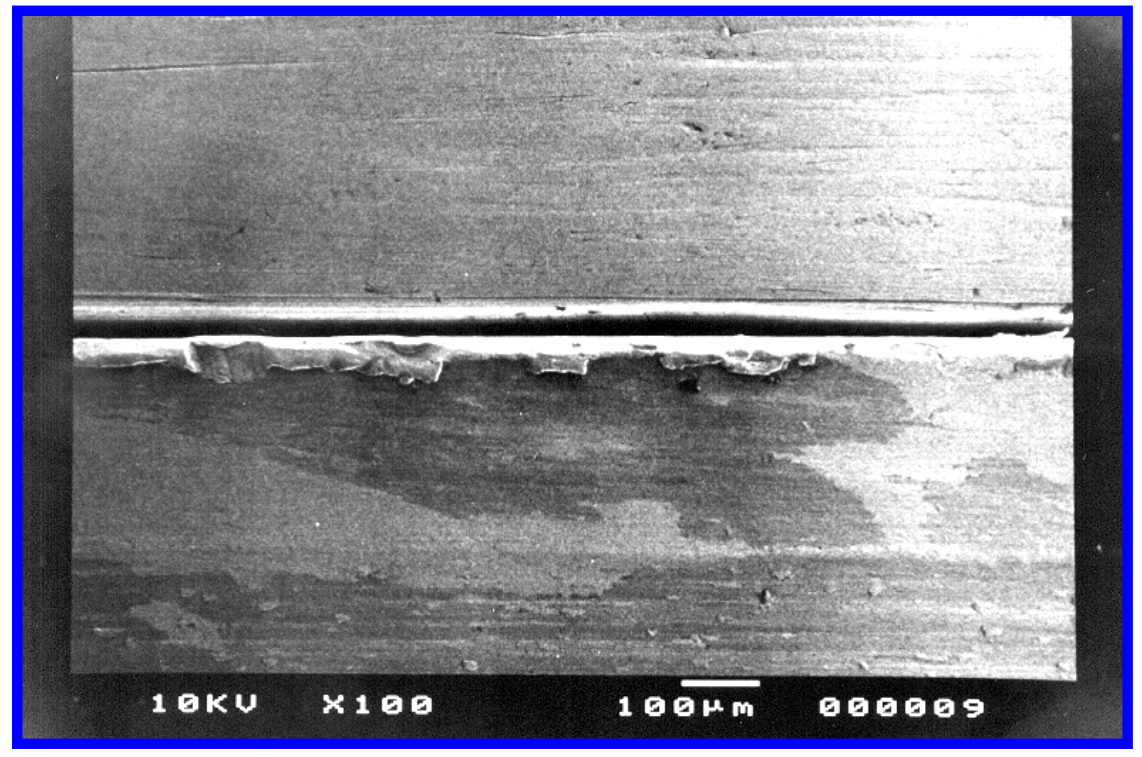

Figura 6.1: Fotomicrografia da interface cilindro/intermediário do grupo I. mostrando alteração da adaptação vertical e irregularidades no bordos.

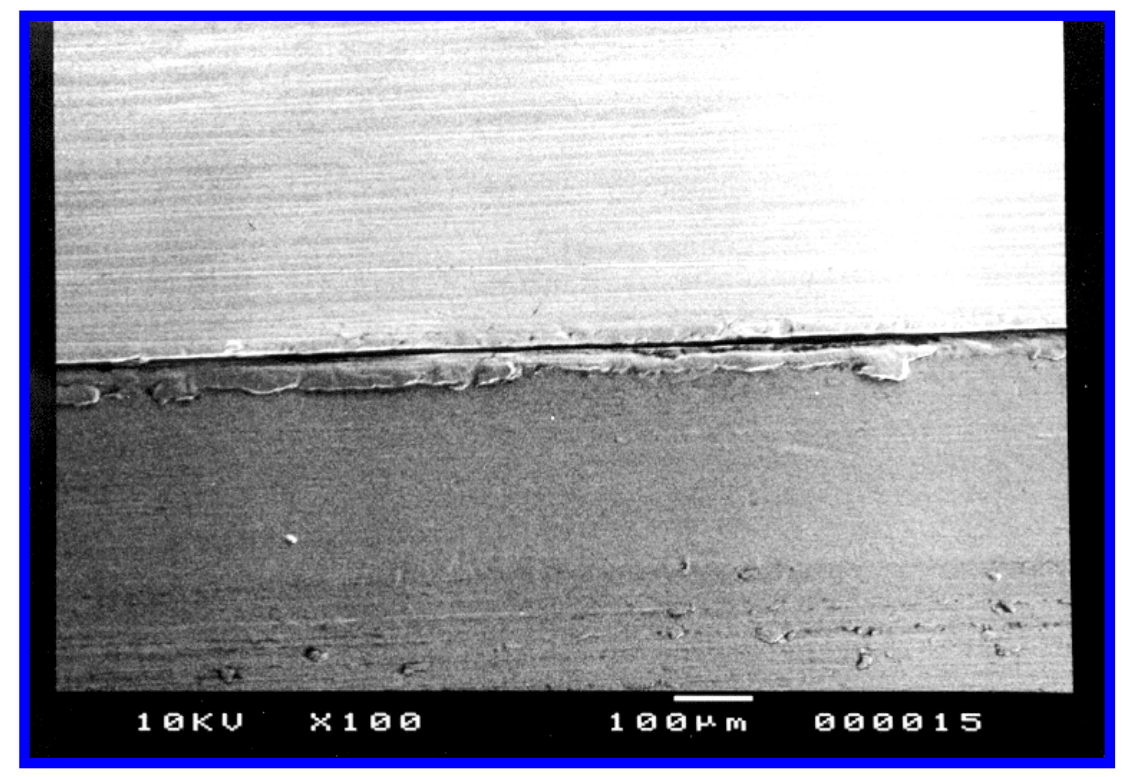

Figura 6.2: Fotomicrografia da interface cilindro/intermediário do grupo II, mostrando alteração da adaptação vertical e irregularidades nos bordos. 
Estes achados são também relatados na literatura em que se pode observar que alterações na adaptação vertical dos componentes foram encontradas também por BINON ${ }^{15}$.

Nos grupos I e II avaliados, foram encontradas médias da adaptação vertical entre 3,68 e 17,26 $\mu \mathrm{m}$, ao torque de 10 e $20 \mathrm{Ncm}$, mostradas no gráfico 6.1.

Gráfigo 6.1: Representação gráfica das médias da adaptação vertical expressas em micrometros dos grupos I e II, ao torque de 10 e $20 \mathrm{Ncm}$, antes da sobrefundiçao.

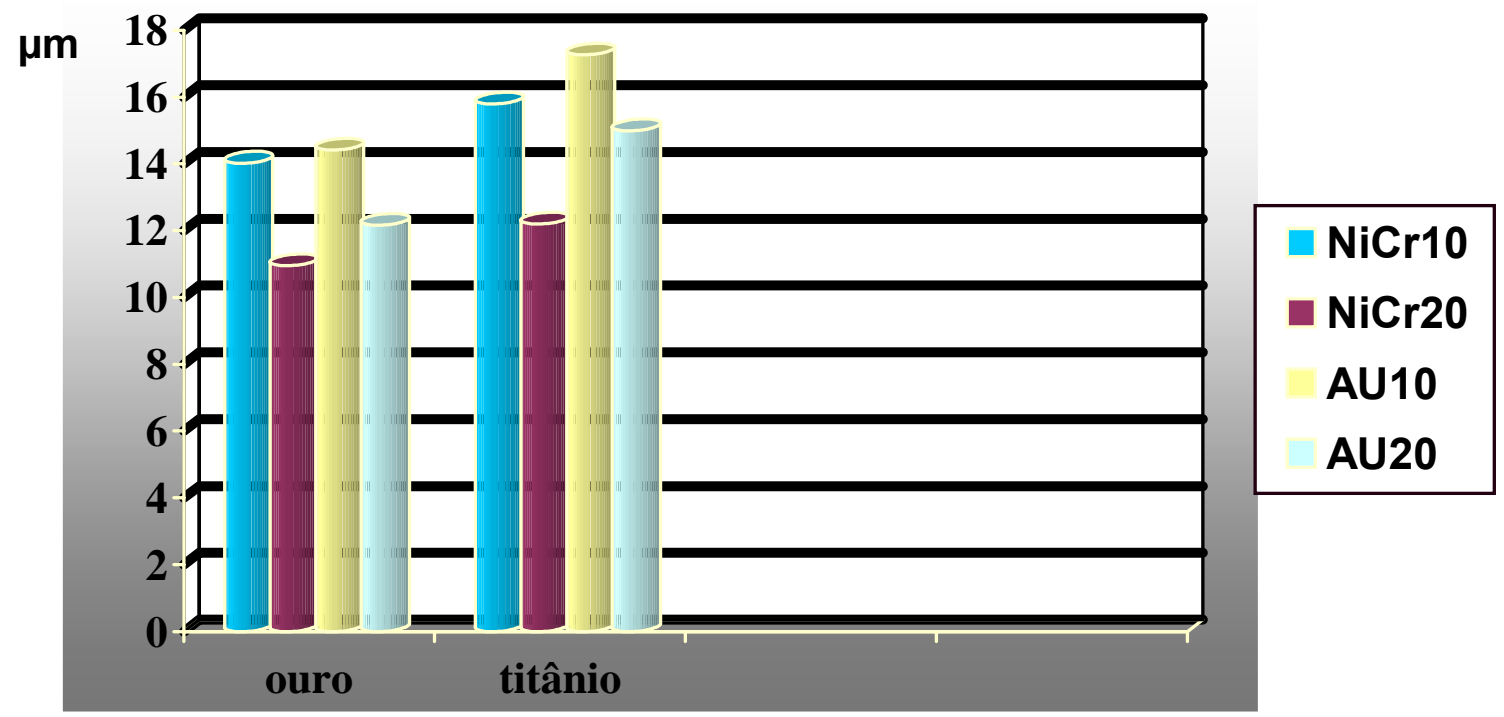

Ao se compararem os valores de adaptação vertical nos grupos estudados, com resultados reportados na literatura, é possível observar diferenças que podem estar relacionadas às alterações próprias dos componentes e as metodologias empregadas. 
Assim, no trabalho de $\mathrm{KANO}^{57}$, que serviu como base na metodologia empregada em nossas avaliações, houve médias de desadaptação vertical de 9,50 $\mu \mathrm{m}$, nos sistemas Implamed, 3i, Lifecore, Conexão e Nobel Biocare. Em nossas avaliações, obtivemos médias para o grupo I e II entre 3,69 a 17,26 $\mu \mathrm{m}$, ao torque de 10 e $20 \mathrm{Ncm}$ antes da sobrefundição.

O trabalho de TAVAREZ ${ }^{108}$, que avaliou desadaptação da interface implante/pilar nos sistemas UCLA cimentado, Emfils cimentado, TMI cimentado, UCLA parafusado e Ceraone cimentado, encontrou médias de desadaptação entre 3,85 e $12,88 \mu \mathrm{m}$. Temos que deixar claro que, nesse caso, os sistemas foram avaliados na interface pilar/implante, enquanto que no nosso trabalho foi avaliada a interface intermediário/cilindro que torna difícil realizar comparação.

Ao se comparar a adaptação vertical dos grupos estudados antes da sobrefundição, foram encontradas diferenças estatisticamentes significantes entre os grupos I e II quando utilizamos parafusos de fixação de ouro (Tabela 5.1) e titânio (Tabela 5.2). Isso é representado pelas Figuras 6.3, 6.4, 6.5 e 6.6. 


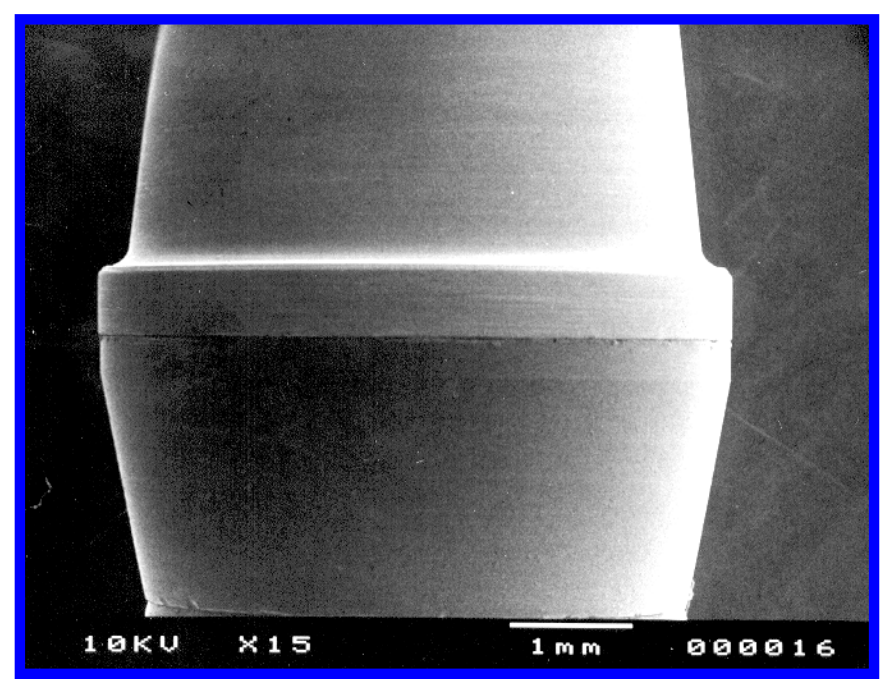

Figura 6.3: Exemplo de cilindro de ouro ( grupo I) com adaptação vertical adequada.

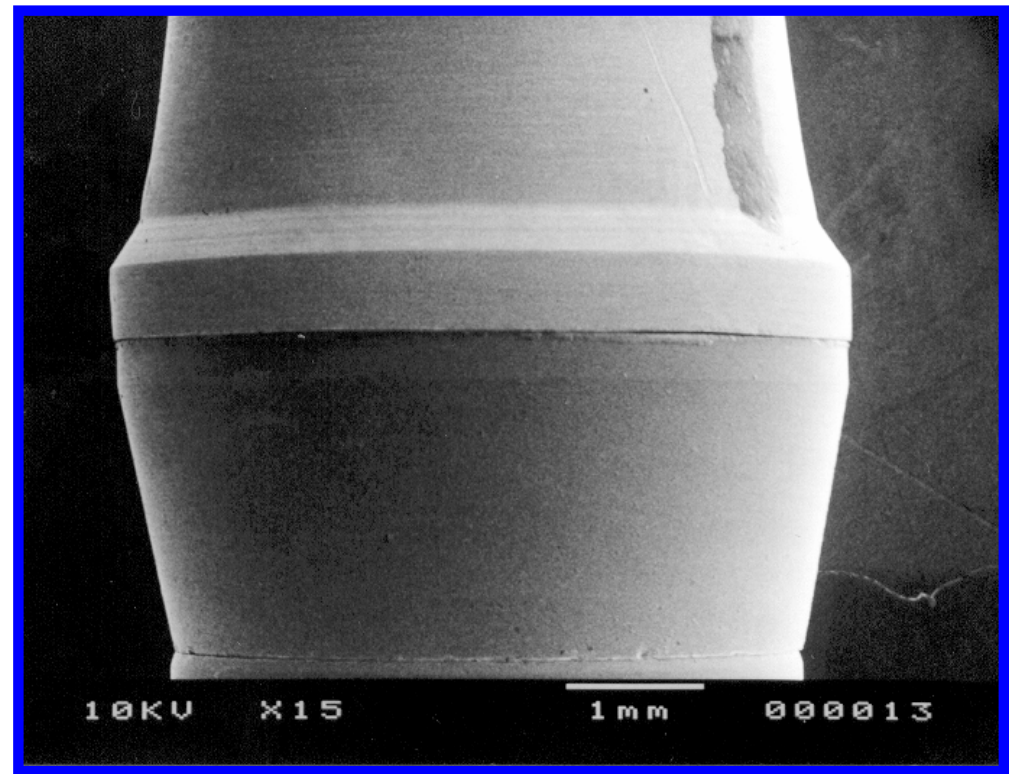

Figura 6.4: Exemplo de cilindro de ouro (grupo I) com imperfeições adaptação vertical. 


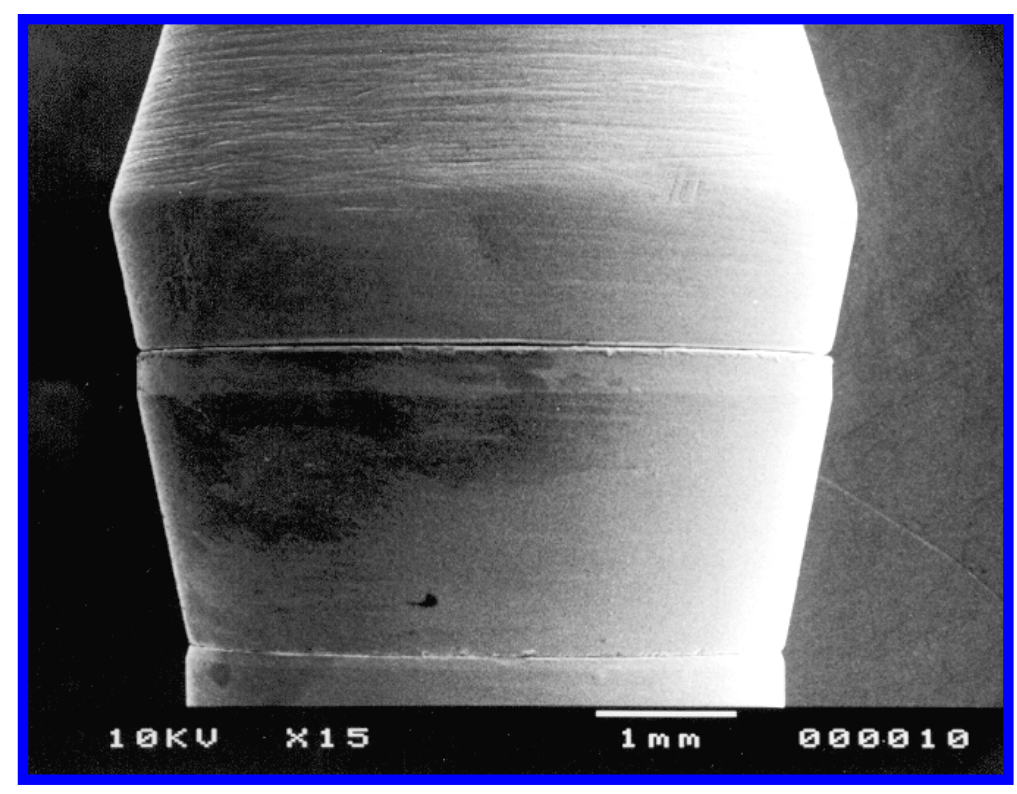

Figura 6.5: Exemplo do cilindro de NiCr (grupo II) com adaptação vertical adequada.

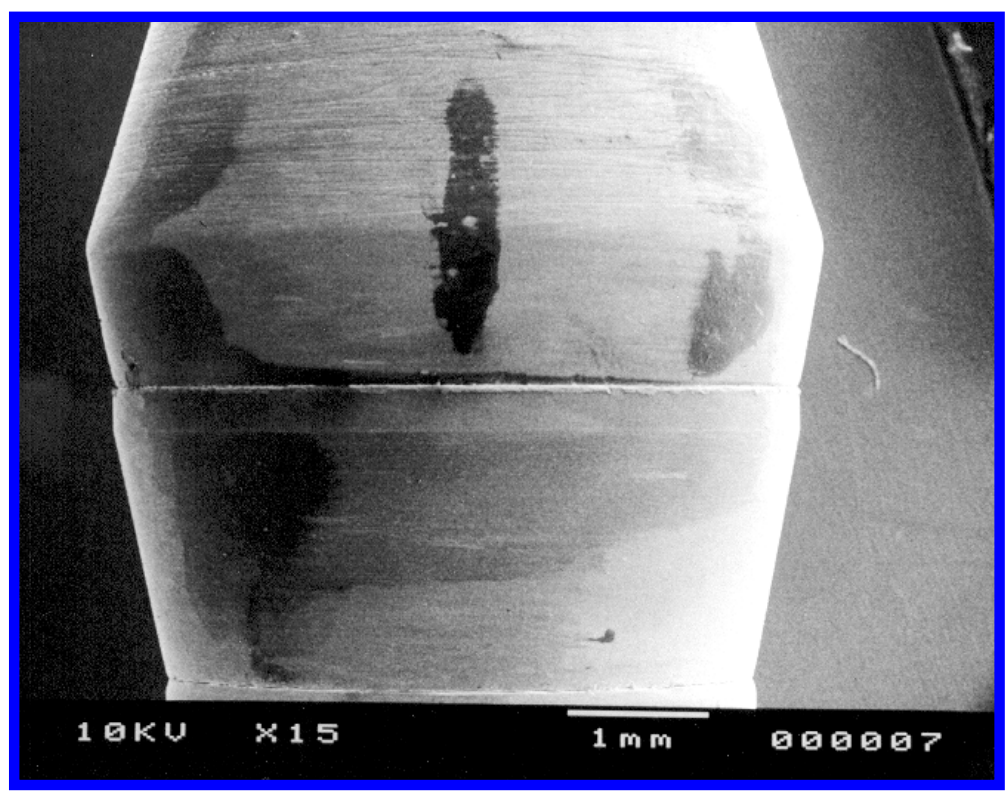

Figura 6.6: Exemplo do cilindro de NiCr (grupo II) com imperfeições de adaptação vertical. 
A adaptação é considerada importante por ter uma relação direta com a estabilidade da união intermediário/cilindro. Uma pobre adaptação ou desadaptação dos componentes tem como conseqüência uma menor área de superfície de contato entre o intermediário e o cilindro na circunferência da conexão. Assim, a desadaptação leva a uma menor estabilidade, favorecendo micromovimentos entre as partes, provocando maiores tensões sobre a união, e conseqüentemente, levando ao afrouxamento do parafuso.

Dessa forma, quando a interface não está corretamente alinhada, devido à desadaptação, a rigidez do conjunto é seriamente comprometida BINON ${ }^{14}$. Nessa situação, o torque aplicado no parafuso para o aperto é primeiramente direcionado para o assentamento das partes afetando, assim, a produção da précarga. É importante deixar claro que a função do parafuso é apenas manter as partes unidas, já em contato, por uma força de travamento e não aproxima-las sob tensão.

A forma, tamanho, material de revestimento do parafuso e a condição de manutenção da pré-carga também têm sido bastante estudos e reportados na literatura ${ }^{85}$. Afirmaram que a ausência de adaptação passiva faz com que as superfícies dos componentes não entrem em contato quando é aplicada a précarga, fazendo com que o parafuso receba toda a carga e diminua sua resistência à fadiga. Observaram, também, duas áreas onde existe uma maior concentração de tensão nos parafusos de fixação e onde provavelmente, se inicia a fadiga. A primeira está entre a haste e cabeça do parafuso, que é uma conseqüência do raio e o diâmetro da curvatura, e a primeira rosca que é conseqüência da geometria e onde se concentra uma grande quantidade de tensão. 
Nesse sentido, BURGUETE et al. ${ }^{19}$ afirmaram que a pré-carga depende do coeficiente de fricção, da geometria das roscas e das propriedades do material; sendo o primeiro fator de maior relevância, já que depende da dureza do material, do polimento da superfície, da quantidade e propriedade do lubrificante e da velocidade do aperto. Assim, o coeficiente de fricção aumenta com a dureza do material e a rugosidade da superfície; e diminui com o emprego de lubrificação. Também, JØRNEUS et al. ${ }^{56}$ mostraram que o desenho da cabeça do parafuso, material do parafuso e o aperto são parâmetros significantes na estabilidade.

Outros estudos mostraram que a condição de produção de pré-carga dos parafusos de ouro é superior quando comparada com os parafusos de titânio. Essa condição é sugerida por JAARDA; RAZOOG; GRATTON ${ }^{48}$, como conseqüência de que a resistência ao escoamento da liga de ouro permite uma maior elongação que a liga de titânio, a qual possui maior resistência ao escoamento. Assim quando o parafuso de ouro é submetido a um torque recomendado pelo fabricante, de $32 \mathrm{Ncm}$, produz uma pré-carga de 468,2N, enquanto no parafusamento de titânio com um torque recomendado pelo fabricante de $20 \mathrm{Ncm}$, produz uma pré-carga de $381,5 \mathrm{~N}$.

Contrariamente a esses estudos JAARDA; RAZZOOG; GRATTON ${ }^{49}$ submeteram cinco diferentes tipos de parafusos de ouro e de titânio a testes de tração, e encontrando diferenças estatisticamentes significantes na resistência à tração e ao cisalhamento em todos os parafusos testados, quando comparados com os parafusos de ouro Nobelpharma. Porém determinaram que a máxima resistência à tração foi encontrada em um parafuso de titânio. Os autores afirmaram que a grande variabilidade nos resultados em relação ao tipo de liga utilizada, pode ter influência no comportamento diferente dos parafusos de 
retenção de ouro e de titânio. Também RAFEE et al. ${ }^{88}$ submeteram parafusos de retenção de ouro a testes de resistência à tração, sob condição de repetidos torques e de contaminação, encontrando que os mesmos podem ser apertados e removidos acima de 20 vezes sem afetar a resistência à tração, e que a contaminação com saliva humana não afeta a resistência dos mesmos.

Já para BINON ${ }^{12}$, diferentes condições podem levar a um inadequado aperto do parafuso:

- Baixa pré-carga na união do parafuso e uma inadequada força de travamento;

- Falhas no reaperto do parafuso após a inserção e assentamento inicial;

- Variáveis induzidas pelo operador na aplicação do torque;

- Dificuldade de acesso na região posterior da boca;

- Variação do torque produzido pelos diferentes dispositivos mecânicos.

Em nosso trabalho, os parafusos utilizados para os grupos I e II foram os de liga de ouro e titânio, variando o torque aplicado de 10 e $20 \mathrm{Ncm}$, como mostra a Tabela 5.5.

Assim, foi encontrado que a liga dos parafusos de fixação não interfere na adaptação. Porém os parafusos ao receberem um torque de $20 \mathrm{Ncm}$, antes da sobrefundição, tem diminuida numericamente a adaptação vertical entre intermediário/cilindro.

A eficiência do torque pode ser realizado através de torquímetros. Foi utilizado o Torque Controler (Nobel Biocare) neste experimento minuciosamente aferido antes de iniciar, pois torquímetros podem variar não dando o torque preciso nas próteses. Os torquímetros elétricos podem ser considerados os mais precisos $^{102}$. Em um estudo comparando três dispositivos para torque Nobel 
Biocare, Strauman ITI e Dyna Torq ITL, concluíram que o elétrico foi o mais preciso e que os torquímetros devem sempre ser aferidos, pois um correto torque evita problemas, comparando também aos torques manuais, quando cada pessoa o aplica de uma forma e um valor, não devendo ser usado ${ }^{37}$.

Um outro aspecto que poderia influenciar na condição de uma boa adaptação vertical seria o torneamento ou fundição dos cilindros para confecção das próteses sobre implantes osseointegrados. As ligas metálicas áureas e suas características vêm sendo alvo de discussão na Odontologia, sendo também as mais indicadas para próteses sobre implantes devido a sua boa adaptação ${ }^{42}$. Porém, com o seu custo muito elevado, os profissionais passaram a utilizar ligas não nobres em seus trabalhos.

Com o propósito de diminuir os custos e favorecer as diferentes condições sociais da população, começou-se a estudar e pesquisar outras ligas não preciosas para fabricação de próteses metalo-cerâmica ${ }^{69}$, sendo elas à base de cabalto-crômio, ou cobalto-níquel-crômio. Nelas observou-se uma forte união do níquel ao opaco de várias porcelanas. A liga de $\mathrm{NiCr}$, aparece cada vez mais acentuada nos nossos trabalhos clínicos. proporcionando mais confiança na sua indicação devido a características tais como: módulo de elasticidade superior, densidade menor, resistência nove vezes maior e menor flexibilidade ${ }^{83}$.

Uma técnica mundialmente aceita e que determina uma excelente precisão é a utilização de cilindros pré-fabricados de ouro $5,61,42,56,67$. Apesar de possibilitar boas propriedades biológicas, físicas e de adaptação, essas ligas ainda apresentam o problema do alto custo, não se enquadrando nas condições econômicas de grande parte da população que necessita de um tratamento protético reabilitador. 
Uma das curiosidades deste trabalho foi a avaliação de cilindros préfabricados em ouro ${ }^{22}$ tipo IV (Conexão Sistemas De Prótese-São Paulo-SPBrasil), os quais são utilizados em grande parte das pesquisas e em tratamentos restauradores sobre implantes, por serem os mais aceitos, e de $\mathrm{NiCr}$ (Viron 99) pré fabricado em um laboratório (C.O.B.E.-Bauru-SP-Brasil) utilizados para confecção de próteses unitárias sobre intermediários tipo esteticone. Os cilindros pré fabricados em liga não nobre foram inseridos nesta pesquisa devido ao fato de serem mais baratos e para verificarmos se realmente podemos usá-los na prática diária. As ligas a base de $\mathrm{NiCr}$ não apresentam propriedades tóxicas, alérgicas, carcinogênicas, apresentando uma experiência clínica de longo prazo ${ }^{27}$. Isso porque, restaurar um dente, necessita-se de uma pequena quantidade, e também por apresentarem uma adaptação marginal aceitável. Comparada ao ouro, seu custo é bem reduzido ${ }^{69}$.

Relatando isso, observamos que existe no mercado inúmeras ligas para sobrefundição desses cilindros e que as mais utilizadas também são as ligas áureas, por terem uma excelente capacidade de adaptação marginal como vantagem e, como desvantagem, o custo muito elevado. Essa liga serve de parâmetro para comparação em quase todos os trabalhos de próteses sobre implantes $22,74,109$.

A liga para sobrefundição dos cilindros de ouro utilizada neste trabalho foi à base de paládio-prata (Proton, La Croix LTDA- Rio de Janeiro- RJ- Brasil), pois relata-se na literatura a sua adaptação marginal semelhante à liga de ouro, podendo ser considerada sua substituta $39,82,83,84$.

A outra liga utilizada para a sobrefundição dos cilindros de Ni-Cr foi à base de Ni-Cr (Vera-Bond II- Aldadent- Califórnia- USA) devido aos relatos anteriores, 
nesse trabalho. Nos procedimentos de confecção de próteses sobre implantes, seu uso era restrito devido o seu alto ponto de fusão. Como antes a fabricação dos cilindros protéticos era à base de ouro seria impossível a utilização dessas ligas, pois o ouro apresenta um ponto de fusão mais baixo em torno de 1370 e $1400^{\circ} \mathrm{C}$, podendo então ocorrer a deformação dos cilindros. Atualmente, vários fabricantes já estão confeccionando cilindros à base de $\mathrm{Ni}-\mathrm{Cr}$, contribuindo assim para uma adaptação vertical melhorada entre a prótese e intermediário e, conseqüentemente, com menor custo $^{98}$. Por isso, a inclusão dessa liga nesta estudo. Outros autores pesquisam outras ligas como por exemplo ligas de titânio e cobalto-cromo para fundição de infra-estruturas de próteses sobre implantes ${ }^{16,24}$, verificando a possibilidade de usa-las.

É indicado que a prótese se relacione com o intermediário unicamente através da base do cilindro de ouro o do parafuso da prótese de forma passiva ${ }^{21}$. Contatos internos, que porventura venham a se estabelecer entre a superfície interna do cilindro de ouro com a superfície externa do intermediário, funcionam como geradores de tensão nos componentes do sistema. Em relação a esse fato, são feitas considerações importantes quando o sistema estético cônico é utilizado uma vez que existe um componente participando da adaptação vertical. Qualquer contato interno acrescentado agirá como um erro angular, capaz de gerar momentos de flexão nos componentes e no osso, gerando cargas estáticas que seriam potencializadas no momento do uso $^{43}$. Para se conseguir uma adaptação aceitável alguns autores recomendam o uso de componentes protéicos usinados, verificação de adaptações entre os componentes clínicos e laboratoriais, a precisão do modelo de trabalho, usar réplicas do implante ou intermediário nova, limpar os cilindros antes da inclusão e usar capas de proteção para os cilindros 
durante acabamento e polimento das infra-estruturas ${ }^{11,38}$. Devido a todos esses fatores a adaptação, que deveria ser passiva, das próteses implanto-suportadas tem merecido grande destaque na literatura e em algumas referências citadas neste trabalho referenciam-na $a^{21,42,43,46,79,110,113,116}$. Uma adaptação vertical aceitável entre à prótese e intermediário é aproximadamente de $50 \mu \mathrm{m}$, pois não gera tensão ao sistema restaurador ${ }^{21}$. A precisão da adaptação entre o intermediário do implante e o componente protético da infra-estrutura tem sido questionado como fator significante na transferência do estresse para a biomecânica destas restaurações e consequentemente na ocorrência de complicações e respostas desagradáveis para os tecidos da interface biológica ${ }^{21}$.

Então, após a sobrefundição, as médias encontradas, neste trabalho, para a adaptação vertical entre intermediário/cilindro, foi de 3,25 e 21,46um como mostra o gráfico 6.2 .

Gráfico 6.2: Representação gráfica das médias da adaptação vertical expressas em micrometros do grupos I e II, ao torque de 10 e $20 \mathrm{Ncm}$, após a sobrefundição.

$\mu \mathrm{m}$

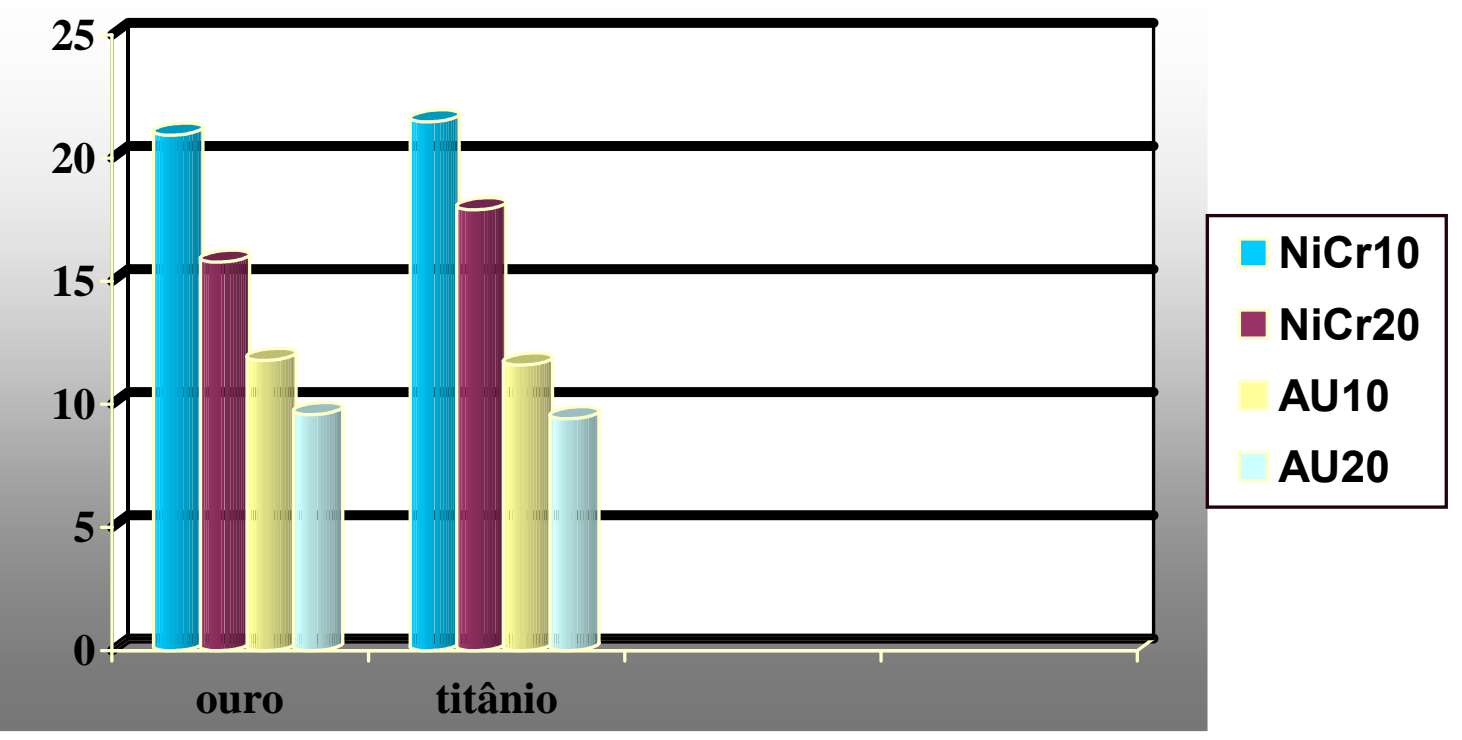


Vários estudos mediram essa interface vertical após a sobrefundição e, quando se comparam os valores encontrados neste estudo com os descritos na literatura, é possível observar diferenças relacionadas a metodologias empregadas.

Então, em seu trabalho SERENSEN; AVERA; TOMAZ ${ }^{99}$, observaram a interface vertical entre intermediários e componentes protéticos de diferentes sistemas e chegaram aos seguintes resultados, sendo que, no grupo $3 \mathrm{i}$, a

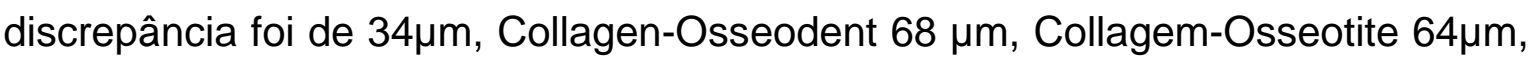
e Nobelpharma $98 \mu \mathrm{m}$.

KEITH et al. ${ }^{61}$, em seu estudo relataram que restaurações parafusadas apresentaram menor desadaptação $(2.6 \mu \mathrm{m}$ antes da sobrefundição, $6.0 \mu \mathrm{m}$ após a sobrefundição e $8.8 \mu \mathrm{m}$ após o acabamento da coroa); e para as restaurações cimentadas (32 $\mu \mathrm{m}$ antes da sobrefundição, $54 \mu \mathrm{m}$ após a sobrefundicão e entre 54,4 a 67,4 $\mu \mathrm{m}$ após a cimentação). Em nossas avaliações, obtivemos médias entre 3,25 a $20,93 \mu \mathrm{m}$ para o grupo I e II, quando o parafuso de fixação era de

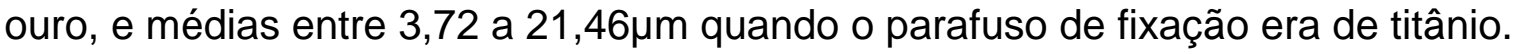

O trabalho de GUICHET et al. ${ }^{42}$ expõe que quando as próteses cimentadas $(45,0 \pm 29,1 \mu \mathrm{m})$ e parafusadas $(46,7 \pm 29,8 \mu \mathrm{m})$ são apenas superpostas em seus intermediários a média de desadaptação é semelhante. Após o parafusamento a média caiu para $18,5 \pm 8,1 \mu \mathrm{m}$ e após a cimentação a média foi similar a anterior $(49,1 \pm 26,3 \mu \mathrm{m})$.

Ao se comparar a adaptação vertical entre intermediários /cilindros, após a sofrefundição nos grupos estudados, foram encontradas diferenças estatisticamente significantes entre os grupos I e II. No grupo I, onde cilindros de ouro receberam sobrefundição com a liga de PdAg, a adaptação vertical melhorou 
numericamente podendo isso ser atribuído ao padrão de deformação do cilindro e escoamento da liga. Também observou-se que a liga do parafuso e a variação do torque não contribuíram na melhora da adaptação. Já no grupo II, onde os cilindros de $\mathrm{NiCr}$ foram sobrefundidos com uma liga de $\mathrm{NiCr}$, a adaptação vertical diminuiu provavelmente devido à dureza dessa liga.

Porém, quando houve aumentou de torque nos cilindros de ouro e $\mathrm{NiCr}$, antes e após a sobrefundição, para verificar se ocorreria uma melhor adaptação, observou-se que sim. Através de uma análise entre todos os artigos lidos sobre desadaptação vertical entre cilindros e intermediários citados neste experimento, conclui-se que deverão existir diferentes níveis de tolerância na confecção de próteses sobre implantes.

Para diminuir essa desadaptação, sugeriram a aplicação do torque correto e se possível 0 aumento deste ${ }^{85}$; torquímetros aferidos para torques apropriados $^{37}$; minuciosa transferência do implante ou intermediário para confecção de um modelo de trabalho preciso, componentes adaptados entre si e novos $^{38}$ e, preferencialmente, utilizar componentes protéicos usinados pelos fabricantes ${ }^{73}$.

O sucesso de restaurações protéticas unitárias é, então, consagrado $3,5,32,35,44,51,52,63,71,87$.

A boa adaptação conseguida neste trabalho também poderá ser atribuída ao fato de os cilindros serem anti-rotacionais, pois se encaixam aos intermediários justamente. Quanto menor for esta liberdade entre as superfícies internas, menor será a desadaptação e, conseqüentemente, aumentará a estabilidade dos parafusos $^{66,111}$. 
Então, restaurações protéticas unitárias parafusadas sobre implantes devem ser usadas. Embora sabendo que aquelas fundidas em ligas nobres ou semi-nobres são melhores porém os resultados encontrados para a liga de $\mathrm{NiCr}$ também são aceitáveis, e que existe um vasto campo para compreender as condições biomêcanicas das próteses parafusadas sobre implantes, e outros trabalhos necessitam ser realizados. 



\section{7- Conclusões}

Com base nos resultados obtidos e na análise e interpretação destes, concluiu-se que:

1. A adaptação vertical da interface entre intermediário do tipo esteticone cilindro pré-usinado de ouro se mostrou-se numericamente superior.

a. O cilindro de ouro, após a sobrefundição, ainda mostrou-se superior em relação ao NiCr;

b. Após a sobrefundição, ambos se mantiveram com alterações aceitáveis.

2. Na condição cilindro de ouro/sobrefundição, o parafuso de fixação de ouro não interferiu significativamente na condição de adaptação da liga nos

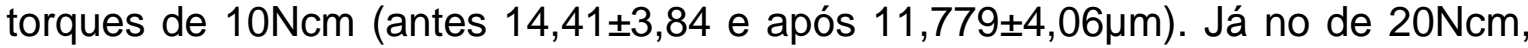

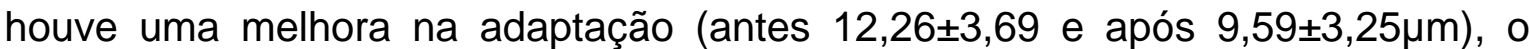
mesmo ocorrendo para a condição de cilindro $\mathrm{NiCr} /$ sobrefundição nos torques de 10Ncm (antes $14,02 \pm 5,63$ e após $20,93 \pm 7,10 \mu m$ ) e no torque de $20 \mathrm{Ncm}$ (antes

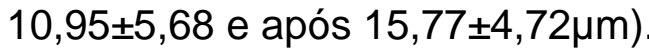

3. Na condição cilindro de ouro/sobrefundição, o parafuso de fixação de titânio não interferiu significativamente na condição de adaptação da liga nos

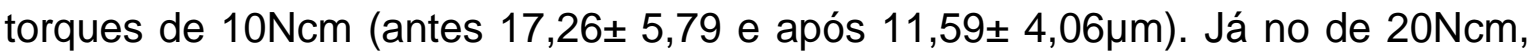

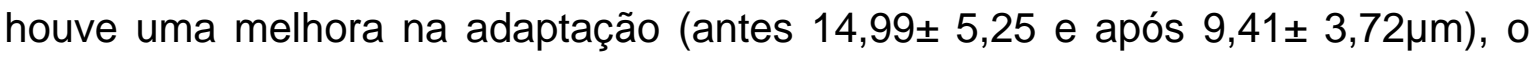
mesmo ocorrendo para a condição de cilindro NiCr/sobrefundição nos torques de 10Ncm (antes $15,79 \pm 5,87$ e após $21,46 \pm 7,10 \mu m$ ) e no torque de $20 \mathrm{Ncm}$ (antes

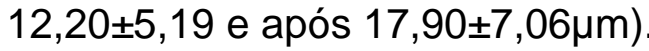


4. A utilização de cilindros pré-usinados mais parafusos de ouro e/ou titânio mostrou-se adequada e compatível, dando uma melhor perfórmance para as condições de ouro em relação ao $\mathrm{NiCr}$. 
ANEXOS 


\section{Anexos}

Anexo 1 - Medidas individuais da adaptação vertical das amostras antes e após a sobrefundição (em micrometros) com parafuso de titânio

\begin{tabular}{|c|c|c|c|c|c|c|c|}
\hline Ni-Cr10 & Ni-Crn10 & Ni-Cr20 & Ni-Crn20 & Ou10 & Oup10 & Ou20 & Oup20 \\
\hline 11,49 & 20,27 & 9,33 & 18,49 & 17,16 & 5,94 & 13,72 & 4,38 \\
\hline 14,55 & 15,38 & 11,11 & 13,27 & 18,77 & 9,38 & 16,77 & 6,83 \\
\hline 21,05 & 26,16 & 14,77 & 21,16 & 20,61 & 13,99 & 19,33 & 11,27 \\
\hline 11,66 & 36,44 & 7,61 & 32,77 & 20,38 & 11,61 & 18,05 & 8,99 \\
\hline 16,33 & 20,61 & 14,49 & 16,88 & 11,61 & 19,83 & 10,49 & 16,83 \\
\hline 12,11 & 19,61 & 8,94 & 14,49 & 8,11 & 10,94 & 6,38 & 8,33 \\
\hline 27,77 & 20,83 & 23,16 & 17,38 & 14,72 & 9,83 & 12,49 & 7,72 \\
\hline 11,38 & 12,44 & 8,22 & 8,77 & 26,72 & 11,22 & 22,72 & 11,00 \\
\hline
\end{tabular}

Anexo 2 - Medidas individuais da desadaptação vertical das amostras antes e após a sobrefundição (em micrometros) com parafuso de ouro

\begin{tabular}{|c|c|c|c|c|c|c|c|}
\hline Ni-Cr10 & Ni-Crn10 & Ni-Cr20 & Ni-Crn20 & Ou10 & Oup10 & Ou20 & Oup20 \\
\hline 11,55 & 19,77 & 8,66 & 15,61 & 13,49 & 5,55 & 11,16 & 3,72 \\
\hline 12,33 & 15,83 & 9,16 & 14,27 & 18,94 & 10,16 & 16,16 & 9,05 \\
\hline 21,66 & 26,66 & 17,94 & 20,88 & 17,66 & 12,88 & 15,77 & 10,72 \\
\hline 22,83 & 33,66 & 19,77 & 23,38 & 18,72 & 10,94 & 16,27 & 8,66 \\
\hline 16,38 & 21,33 & 13,61 & 13,44 & 11,66 & 19,99 & 10,44 & 15,55 \\
\hline 8,66 & 19,27 & 3,16 & 13,77 & 7,77 & 11,44 & 5,49 & 10,27 \\
\hline 9,27 & 21,33 & 6,77 & 16,83 & 13,55 & 10,16 & 11,77 & 8,61 \\
\hline 9,49 & 9,61 & 8,55 & 8,05 & 13,55 & 13,22 & 11,05 & 10,16 \\
\hline
\end{tabular}


Anexo 3 - Teste não paramétrico de Wilcoxon $(p<0,05)$ - parafuso de ouro , antes e após as fundições

\begin{tabular}{|c|c|c|}
\hline Comparação & $\mathbf{Z}$ & $\mathbf{p}$ \\
\hline TI10 x Tin10 & $-2,52$ & $0,005^{\star}$ \\
\hline Ti20 x Tin20 & $-2,10$ & $0,017^{\star}$ \\
\hline Ou10 x Oup 10 & 1,12 & 0,86 \\
\hline Ou20 x Oup20 & 1,40 & 0,91 \\
\hline
\end{tabular}

* significante para $p<0,05$

Anexo 4 - Teste não paramétrico de Wilcoxon $(p<0,05)$ - parafuso de titânio

\begin{tabular}{|c|c|c|}
\hline Comparação & $\mathbf{Z}$ & $\mathbf{p}$ \\
\hline Ti10 $\times$ Tin10 & $-1,82$ & $0,03^{\star}$ \\
\hline Ti20 $\times$ Tin20 & $-1,82$ & $0,03^{\star}$ \\
\hline Ou10 x Oup 10 & 1,82 & 0,96 \\
\hline Ou20 x Oup20 & 1,96 & 0,97 \\
\hline
\end{tabular}

* significante para $p<0,05$ 
REFERÊNCIAS BIBLIOGRÁFICAS 


\section{Referências Bibliográficas ${ }^{1}$}

1. ABOYOUSSEF, H.; WEINER, S.; EHRENBER, G. Effect of an antirotation resistance form on screw loosenig for single implant-supported crowns. J. Prosthet. Dent., v.83, n.4, p.450-455, 2000.

2. ANUSAVICE, K.J. Noble metal alloys for metal-ceramic restorations. Dent. Clin. North America, v.29, n.4, p.798-803, 1995.

3. ARBER, L.; ZARB, G. Clinical effectiveness of implant supported single tooth replacement: The Toronto study. Int. J. Oral Maxillofac. Implants, v.11, p.311-321, 1996.

4. ARTZI, Z.; DREIANGEL, A. A screw lock for single tooth implant superstructure. J. Am. Dent. Assoc., v.130, p.677-682, 1999.

5. BALSHI, T, et al. A comparative study of one implant versus two replacing a single molar. Int. J. Oral Maxillofac. Implants, v.11, p.372-378, 1996.

6. BALSHI, T, et al. Three-year evaluation of Branemark implants connected to angulated abutments. Int. J. Oral Maxillofac. Implants, v.12, p.5258, 1997.

7. BARAN, G R. Selection criteria for base metal alloy for use with porcelains. Dent. Clin North America. v.24, n.4, pag.779-803

8. BASSIT, R.; LINDSTROM, H.; RANGERT, B. In vivo registration of force development with ceramic and acrylic resin occlusal materials on implant-supported prostheses. Int. J. Oral Maxillofac. Implants, v.17, n.1, p.17-23, 2002.

9. BASTEN, C. et al. Load fatigue performance of two implant-abutment combinations. Int. J. Oral Maxillofac. Implants, v.11, n.4, p.522-528, 1996.

${ }^{1}$ Normas recomendadas para uso no âmbito da Universidade de São Paulo, com base no documento "Referencias Bibliográficas: exemplo", emanada do conselho supervisor do Sistema Integrado de Bibliotecas da USP, em reunião de 20 de setembro de 1990. 
10. BECKER, W.; BECKER, B. Replacement of maxillary and mandibular molars with single endosseous implant restorations: A retrospective study. J Prostetic Dent., v.74, p.51-55. 1995.

11. BINON, P., et al. Implant component compatibility. In : LANEY, W. R., TOLLMAN,D.E. (eds). Tissue Integration in Oral, Orthopedic and Maxillofacial reconstruction. Caroll Streeam, IL. Quintessence Publiishing Co, Cap. 4, p. 218-226,1993.

12. BINON, P. et al. The role of screws in implant systems. Int. J. Oral Maxillofac. Implants, v.9, p.48-63, 1994 (Supplement).

13. BINON, P. Implants and components: Entering the new millennium. Int. J. Oral Maxillofac. Implants, v.15, n.1, p.76-94, 2000.

14. BINON, P. The external hexagonal interterface and screw-joint stability: A primer on threaded fasteners in implant dentistry. Quint. Dent. Tecnolog., p.91-105, 2000.

15. BINON, P.; McHUGH, M. The effect of eliminating implant/abutment rotational misfit on screw joint stability. Int. J. Prosthodont., v.9, n.6, p.511-519. 1996.

16. BONACHELA, W. Avaliação da adaptação da interface intermediários / cilindros de plástico fundidos em titânio e cobalto - cromo, antes e após soldagem a laser variando os parafusos de fixação (fenda e hexágono). Bauru, 2002. 128p. Tese (Livre docencia) - Faculdade de Odontologia de Bauru, Universidade de São Paulo.

17. BRÄNEMARK, $P$. et al. Intraosseus anchorage of dental prostheses: I experimental studies Scand. J. Plast. Reconstru. n. 3, p.81-1000. 1969.

18. BROSCO, H. Precisão de adaptação de intermediários transmucosos unitários em sistemas nacionais de implantes compatíveis em hexágono externo. Bauru, 2001. 100p. Tese (Livre docencia) Faculdade de Odontologia de Bauru, Universidade de São Paulo.

19. BURGUETE, R. et al. Tightening characteristics for screwed joints in osseointegrated dental implants. J. Prosthet. Dent., v.71, n.6, p.592-9, 1994.

20. BYRNE, D, et al. The fit of cast and premachined implant abutments. J. Prosthet. Dent. v.80, n.2, p.184-192, 1998. 
21. CARLSSON, B.; CARLSON, G.E. Prosthodontic complications in osseointegrated dental implant tratment. Int. J. oral Maxillofac. Implants, v.9, n.1, p.90-4, Jan/Feb, 1994.

22. CARR, A.; BRUNSKI, J.; HURLEY, E. Effects of fabrication, finishing, and polishing procedures on preload in prostheses using convencional "gold" and plastic cylinders. Int. J. Oral Maxillofac. Implants, v.11, n.5, p.589598, 1996.

23. CARR, A.B.; GERARG. D.A.; PETER, E. The response of bone in primates around unloaded dental implants supporting prostheses with different levels of fit. J. prosth. Dent.,. v.76, n.5, p.500-509, 1996.

24. CASTILIO, D. Avaliação da adaptação da interface intermediários/cilindros de palástico fundidos em titânio e cobaltocromo, antes e após soldagem a laser. Bauru, 2000. 93p. Dissertação (Mestrado) - Faculdade de Odontologia de Bauru. Universidade de São Paulo.

25. CIBIRKA, R. et al. Examination of the implant-abutment interface after fatigue testing. J. Prosthet. Dent., v.85, n.3, p.268-275, 2001.

26. CHESHIRE, P.D.; HOBKIRK, J.A. An in vitro quantitative analysis of the fit of Nobel Biocare implant superstructures. J. oral Rehabil., v.23, n.11, p.782-89, 1996.

27. Council on Dental Materials, Instruments and Equipment. (National Institute of Dental Research) Workshop: biocompatibility of metals in dentistry. J. Amer. dent. Assoc., v.109, n.3, p.469-71, Sept. 1984.

28. Concil on Dental Materials, Instruments and Equipment Dental Association. Specification of dental casting alloys for crown and briidge application: benefits and risks. J. Amer. dent. Assoc., v. 118, n. 3, p. 379. Mar. 1989.

29. DELLOW, A.; DRIESSEN, C.; NEL, H. Scanning electron microscopy evaluation of the interfacial fit of interchanged components of four dental implant systems. Int. J. Prosthodont., v.10, n.3, p.216-221, 1997.

30. DIXON, D. et al. Comparison of screw loosening, rotation, and deflection among three implant designs. J. Prosthet. Dent., v.74, n.3, p.270-8, 1995. 
31. DUYCK, J.; NAERT, I. Influence of prothesis fit and effect of a luting system on the prosthetic connection preload: na in vitro study. Int. J. Prosthodont. v.15, n.4 , p.389-96. 2002.

32. EKFELDT, A.; CARLSSON, G.; BORJESSON, G. Clinical evaluation of single-tooth restorations supported by osseointegrated implants: $A$ retrospective study. Int. J. Oral Maxillofac. Implants, v.9, p.179-183, 1994.

33. FAULKNER, G.; WOLFAARDT, J.; CHAN, A. Measuring abutment / implant joint integrity with the periotest instrument. Int. J. Oral Maxillofac. Implants, v.14, n.5, p.681-688, 1999.

34. GENG, J-P; TAN, K.B.; LIU, G-R. Application of finite element analysis in implant dentistry: a review of the literature. J. prosth. Dent., v.85, n.6, p. 585-98, June 2001.

35. GIBBARD, L.; ZARB, G. A 5 year prospective study of implant-supported single-tooth replacements. J. Can. Dent. Assoc., v.68, n.2, p.110-116, 2002.

36. GIL, F.J. et al. In vitro corrosion behaviour and metallic ion release of different prosthodontic alloys. Int. dent. J. v.49, n.6, p.361-67, 1999.

37. GOHEEN, K. et al. Torque generated by handheld screwdrivers and mechanical torquing devices for osseointegrated implants. Int. J. Oral Maxillofac. Implants, v.9, p.149-155, 1994.

38. GOLL, G E. Production of accuratelly fitting full-arch implant frameworks: part I - clinical proceduures. J. prosth. Dent., v. 66, n. 3, p. 377-84, Sept. 1991.

39. GOODACRE, C.T. Palladium-silver alloys: a review of the literature. J. prosth. Dent., v. 62, n.1, p.34-37, July 1989.

40. GROSS, M. et al. Manual closing torque in five implant abutment systems: An in vitro comparative study. J. Prosthet. Dent., v.81, n.5, p.574-578, 1999.

41. GROSS, M.; ABRAMOVICH, I.; WEISS, E. Microleakage at the abutment implant interface of osseointegrated implants: A comparative study. Int. J. Prosthodont., v.14, n.1, p.94-100, 1999. 
42. GUICHET, D. et al. Passivity of fit and marginal opening in screw or cement retained implant fixed partial denture designs. Int. J. Oral Maxillofac. Implants, v.15, n.2, p.239-246, 2000.

43. GYLLENRAM, F. Handling and hardware. The two ultimate parameters for a clinically a acceptable fit. Nobelpharma News. v.8,n.4,p.4-5, 1994.

44. HASS, R. et al. Bränemark single tooth implants: A preliminary report of 76 implants. J Prostetic Dent.; v73, p274-279, 1995.

45. HEBEL, K.; GAJJAR, R. Cement-retained versus screw-retained implant restorations: Achieving optimal occlusion and esthetics in implant dentistry. J Prostetic Dent., v.77, n.1, p.28-35, 1997.

46. HELLDÉN, L.B.; DÉRAND, T. Description and evaluation of a simplified method to achieve passive fit beween cast - titanium frameworks and implants. Int. J. oral Maxillofac. Implants, v. 13, n. 2, p. 190-6, 1998.

47. ISA, Z. M.; HOBKIRK, J. A. The effects of superstructure fit and loading on individual implant units: part I. the effects of tightening the gold screws and placement of a superstructure with varying degrees of fit. Eur. J. Prosthodont. Restorat. Dent., v. 3, n. 6, p. 247-53, 1995.

48. JAARDA, M; RAZZOOG, M.; GRATTON, D. Ultimate tensile strength of five interchangeable prosthetic retaining screws. Implant Dent., v, 5, p,1619, 1996.

49. JAARDA, M.; RAZZOOG, M.; GRATTON, D. Geometric comparison of five interchangeable implant prosthetic retaining screws. J. Prosthetic. Dent., v.74, n.4, p.373-379, 1995.

50. JANSEN, V.; CONRADS, G.; RICHTER, E. Microbial leakage and marginal fit of the implant-abutment interface. Int $\mathbf{J}$ Oral Maxillofac Implants; v.12, n.4, p.527-540, 1997.

51. JEMT, T. et al. Osseointegrated implants for single tooth replacement: A 1year report from a multicenter prospective study. Int. J. Oral Maxillofac. Implants, v.6, p.29-36, 1991.

52. JEMT, T.; LEKHOLM, U.; GRONDAHL, K. A 3 year followup study of early single implant restorations ad modum Branemark. Int. J. Period. Rest. Dent., v.10, p.340-349, 1990. 
53. JEMT, T.; LINDÉN, B.; LEKHOLM, V. Failures and complications in 127 consecutively placed fixed partial prostheses supported by Branemark implants: from prosthetic treatment to first annual checkup. Int. J. Maxillofac. Implants, v.7, n.1, p.40-4, Spr. 1992.

54. JEMT, T., Customized titanium single-implants abutments 2 year follow-up pilot study. Int. J. Prosthodont., v.11, n.4, p. 312-316, 1998.

55. JEMT, T et al. Measuring fit at the implant prostodontic interface. J. prosth. Dent., v.75, n.3, March, p. 314-25, 1996.

56. JORNÉUS, L.; JEMT, T.; CARLSSON, L. Loads and design of screw joints for single crowns supported by osseointegrated implants. Int. J. oral Maxillofac. Implants. v.7, n.3, p.353-9, 1992.

57. KANO, S. Avaliação da interface intermediário / cilindro de ouro e da compatibilidade de diferentes sistemas de implantes odontológicos: Análise intra e entre - sistemas. Bauru, 1998. 91p. Dissertação (mestrado) - Faculdade de Odontologia de Bauru, Universidade de São Paulo.

58. KANO, S.C. Disajustment of prosthetic components using different alloys. J. dent. Res., v.74, n.3, p.806, 1995/Abstract n.206/.

59. KANSU, G.; AYDIN, A.K. Evaluation of the biocompatibility of various dental alloys: part 1- toxic potentials. Europ J. Prosthodont. Restorat. Dent., v.4, n.3, Dec., p.155-61, 1996.

60. KANSU, G.; AYDIN, A.K. Evaluation of the biocompatibility of various dental alloys: part 2- allergenic potentials. Europ J. Prosthodont. Restorat. Dent., v.4, n.3, Dec., p.155-61, 1996.

61. KEITH, S. et al. Marginal discrepancy of screw-retained and cemented metal ceramic crowns on implant abutments. Int. J. Oral Maxillofac. Implants, v.14, n.3, p.369-378, 1999.

62. KOHAVI, D. Complications in the tissue integrated prostheses components: clinical and mechanical evaluation. J. oral Rehab., v. 20, n. 4, p. 413-22, July 1993.

63. KRENNMAIR, G.; SCHMIDINGER, S.; WALDENBERGER, O. Single tooth replacement with the Frialit-2 system: A retrospective clinical analysis of 146 implants. Int. J. Oral Maxillofac. Implants, v.17, p.78-85, 2002. 
64. LANEY, W. et al. Osseointegrated implants for single-tooth replacement: Progress report from a multicenter prospective study after 3 year. Int. J. Oral Maxillofac. Implants, v.9, p.49-54, 1994.

65. LANG, L., et al. The effect of the use of a counter-torque device on the abutment-implant complex. J. Prosthet. Dent., v.81, n.4, p.411-417, 1999.

66. LANG, L.; WANG, R.; MAY, K. The influence of abutment screw tightening on screw joint configuration. J. Prosthetic. Dent., v.87, n.1, p.74-79, 2002.

67. LAZZARA, R. Restorative adavantages of the coronally hexed implant. Compendium, v.XII, n.12, p.924-930, 1991.

68. LEE, J. et al. Wave análisis of implant screw loosening using an air cylindrical cyclic loading divice. Prosthetic. Dent., v.88, n.4, p.402-408, 2002.

69. LEINFELDER, K.F. An evaluation of casting alloys used for restorative procedures. J. Amer. dent. Assoc., v.128, Jan. 1997.

70. LEVINE, R. et al. A multicenter retrospective analysis of the ITI implant system used for single tooth replacements: Preliminary results at 6 or more months of loading. Int. J. Oral Maxillofac. Implants, v.12, p.237242, 1997.

71. LEVINE, R. et al. Multicenter retrospective análisis of the solid-screw ITI implant for posterior single-tooth replacements. Int. J. Oral Maxillofac. Implants, v.17, p.550-556, 2002.

72. LEVINE, R. et al. Multicenter retrospective analysis of the ITI implant system used for single tooth replacements: Results of loading for 2 or more years. Int. J. Oral Maxillofac. Implants, v.14, p.516-520, 1999.

73. LEWIS, S.; LLAMAS, D.; AVERA, S. The UCLA abutment: A four-year review. J. Prosthet. Dent., v.67, p.509-515, 1992.

74. MARIO, J.; LA CROIX, S. P. Estudo de uma liga alteranativa de prata/paládio para uso odontológico. Rev. Bras. Odontol., v.l ,n.6,p.3645, 1993. 
75. MARTINI, W. et al. Implant abutment screw rotations and preloads for four different screw materials and surfaces. J. Prosthetic. Dent., v.86, n.1, p.24-32, 2001.

76. MAY, K.; EDGE, M.; RUSSELL, M, RAZZOOG M, LANG B. The precision of fit at the implant prosthodontic interface. J. Prosthetic. Dent., v.77, n.5, p.497-502, 1997.

77. McGLUMPHY, E.; MENDEL, D.; HOLLOWAY, J. Implant screw mechanics. Dent. Clinics North. Am., v.42, n.1, p.71-89, 1998.

78. MJOR, I.A. Reações adversas aos materiais de prótese dentária. In OWALL, B.; KAISER, A. F.; CARLSSON, G. E. Prótese Dentária: princípios e condutas estratégicas. São Paulo, Artes Médicas, 1997. Cap.13, p.179-86.

79. MILLINGTON, N. D.; LEUNG, T. Stress on na implantsuperstructure in relatio to its accuracy of fit. J. Dent. Res., v.71, p.529./Abstract n.108/

80. MISCH, C. E. Princípios das Próteses Parafusadas. In: Implantes Dentários Contemporâneos. São Paulo, SantoslLivraria e Editora, p.575- 593, 2000.

81. MITRANI, R. et al. Accuracy of electronic implant torque controllers following time in clinical service. Int. J. Oral Maxillofac. Implants., v.16, n.3, p.394-399, 2001.

82. MYERS, G.W.; CRUICKSHANKS - BOYD, D.W. Mechanical properties and casting characteristics of a silver- palladium bonding alloy. Brit. Dent. J., v.153, n.2, p.323-6, nov.1982.

83. MONDELLI, J. Ligas alternativas para restaurações fundidas. São Paulo. Panamericana 1995.

84. MURPHY, W.M. et al. A prospective syear study of two cast framework alloys for fixed implant supported mandibular protheses. Int $\mathbf{J}$. Prosthodont., v.15, n.2, p.133-138, 2002.

85. PATTERSON, E.; JHONS, M. Theoretical analysis of the fatigue life of fixture screws in osseintegrated dental implants. Int. J. Oral Maxillofac. Implants, v.7, p.26-34, 1992. 
86. PESUN, I. et al. Operator-induced axial forces during implant gold screw fastening. J. Prosthet. Dent., v.86, n.1, p.45-19, 2001.

87. PRIEST, G. Single tooth implants and their role in preserving remaining teeth: A 10 year survival study. Int. J. Oral Maxillofac. Implants, v. 14, p.181-188, 1999.

88. RAFEE, M. et al. The effect of repead torque on the ultimate tensile strength of slotted gold prosthetic screws. J. Prosthet. Dent., v.88, n.2, p.176-182, 2002.

89. RAMBHIA, S. et al. Defects in hexed prosthetic screws: A metallographic and tensile analysis. J. Prosthetic. Dent. v.87, n.1, p.30-39, 2002.

90. RASMUSSEN, E.J. Alternative prosthodontic technique for tissueintegrated prostheses. J. Prosthetic. Dent., v.57, n.2, p.198-203, 1987.

91. RIBAS, D.T.C.; RIBEIRO, M. Indicação e utilização da liga alternativa para próteses fixas unitárias. Rev. Brasileira de Odontol., v. 58, n.4, p. 236239, Jul/Ag, 2001.

92. SAHIN, S; ÇEHRELI, M.C. The significance of passive framework fit in implant prosthodontics: current status. J. Implant Dent., v.10, n.2, p. 8590, 2001.

93. SAKAGUCHI, R.L.; BORGERSEN, S.E. nonlinear finite element contact analysis of dental implant components. Int. J. Oral maxillofac. Implants. v. 8, n.6, p. 655-661, 1993.

94. SAKAGUCHI, R.; BORGERSEN, S. Nonlinear contact analysis of preload in dental implant screws. Int. J. Oral Maxillofac Implants, v.10, n.3, p.295-302, 1995.

95. SCHOLANDER, S. A retrospective evaluation of 259 single tooth replacements by the use of Branemark implants. Int. J. Prosthodont., v.12, p.483-491, 1999.

96. SCHULTE, J.; COFFEY, J. Comparison of screw retention of nine abutment systems: A pilot study. Implant Dent., v.6, p.28-31, 1997. 
97. SERTGÖZ, A. Finite element analysis study of the effect of superstructure material on stress distribution in an implant-supported fixed prosthesis. Int. J. Prosthodont., v. 10, n. 1, p. 19-27, Jan./Feb. 1997.

98. SARTORI, I. Análise comparativa da interface intermediário estético/cilindro protético, torneados em ouro ou em plástico, antes e após as fundições. Ribeirão Preto,1999. 121p. Dissertação (mestrados)- Faculdade de Odontologia de Ribeirão Preto , Universidade de São Paulo.

99. SORENSEN, J.A.; AVERA, S. P.; TOMAS, C. Comparasion of interface fidelity of implnt systems. J. Dent. Res. v. 70, n. 3, p. 540, Mar. 1991/Abstract n.2191/

100. SKALAK, R. Biomechanical considerations in osseointegrated prostheses. J. prosth. Dent., v. 49, n. 6, p. 843-8, June 1983.

101. STANDLEE, J.; CAPUTO, A. Accuracy of an electric torque limiting device for implants. Int. J. Oral Maxillofac. Implants, v.14, n.2, p.278-281, 1999.

102. STANDLEE, J. et al., A. Accuracy of mechanical torque limiting devices for implants. Int. J. Oral Maxillofac. Implants, v.17, n.2, p.220-224, 2002.

103. SUTTER, F. et al. The role of screws in implant systems. Int. J. Oral Maxillofac. Implants, v.9, p.48-63, 1994 (Supplement).

104. SUTTER, F.; WEBER, H.; SORENSEN, J. The new restorative concept of the ITI dental implant system: Design and engineering. Int. J. Periodont. Rest. Dent., v.13, n.5, p.409-431, 1993.

105. TAN, K.B. et al. Three-dimensional analysis of the casting accuracy of onepiece, osseointegrated implant-retained prostheses. Int. J. Prosth., v.6, n. 4, p.346-63, July/Aug. 1993.

106. TAN, K.; NICHOLLS, J. Implant-abutment screw joint preload of 7 hex-top abutment systems. Int. J. Oral Maxillofac. Implants, v.16, n.3, p.367377, 2001.

107. TAN, K.; NICHOLLS, J. The effect of 3 torque delivery sustems on gold screw preload at the gold cylinder abutment screw joint. Int. J. Oral Maxillofac. Implants, v.17, n.2, p.175-183. 2002. 
108. TAVAREZ, R. R. J. Análise comparativa das interfaces de implantes de conexão externa e internaem restaurações unitárias cimentadas e parafusadas, antes e após ensaios de fafiga. Bauru, 2003.211p. Tese (Doutorado) - Faculdade de Odontologia de Bauru, Universidade de São Paulo.

109. TJAM, A. et al. Marginal accuray of complete crowns made from alternative casting alloys. J. Prosthent Dent., v.66, n.2, p.157-164, 1991.

110. TAYLOR, T.; AGAR, J.; VOGIATZI, T. Implant prosthodontics: Current perspective and future directions. Int. J. Oral Maxillofac. Implants, v.15, n.1, p.66-73, 2000.

111. VIGOLO, P.; MAJZOUB, Z.; V.; CORDIOLI, G. Measurement of the dimensions and abutment rotational freedom of gold machined 3i UCLAtype abutments in the as-received condition, after casting with a noble metal alloy and porcelain firing. J. Prosthet. Dent., v.84, n.5, p.548-553, 2000.

112. WATSON, P.A. Development and manufacture of prosthodontic components. Dowe nedd changes? Int. J. Prosthodont., v.11, n.5, p. 513-6, 1998.

113. WEE, A. G.; AQUILINO, S. A.; SCHNEIDER, R. L. Strategies to achieve fit in implant prosthodontics: a review of the literature. Int. J. Prosthodont., v. 12, n. 2, p. 167-78, 1999.

114. WEIMBERG, L.A. The brome chances of force distribution in Implantsupported prostheses. Int. Oral Maxillofac. Implants., v. 8, n.1, p. 1931, 1993.

115. WEINBERG, L.; KRUGER, B. A comparison of implant / prosthesis loading with four clinical variables. Int. J. Prosthodont., v.8, n.5, p.421-433, 1995.

116. YANASE, R.T. How do you test a cast framework fit for a full-arch fixed implant-supported prosthesis. Int. J. oral Maxillofac. Implants, v.9, n.4, p.170-4, 1994.

117. ZITZMANN, N.U.; MARINELLO, C.P. A review of clinical and technical considerations for fixed and removable implant prostheses in edentulous mandible. Int. J. Prosthod., v.15, n.1, p.65-72, 2002. 
ABSTRACT 


\section{Abstract}

The fitting of prostheses over implants is regarded as a fundamental factor for their success in the long-term. This study evaluated the vertical fitting between esteticone abutments and anti-rotational prefabricated cylinder implants of several alloys for single-tooth prosthesis. Gold cylinders of the brand Conexao (Conexao Sistemas de Protese - Sao Paulo, SP, Brazil) and nickel-chromium cylinders prefabricated in a commercial laboratory were selected. Measurement of the vertical fitting was conducted in a light microscope, before overcasting with 10 $\mathrm{Ncm}$ and $20 \mathrm{Ncm}$ of torque, with variations in the fixing screws. The measurements ranged from $14.03 \pm 5.63 \mu \mathrm{m}$ for the nickel-chromium cylinders before overcasting with $10 \mathrm{Ncm}$ of torque and $10.95 \pm 5.68 \mu \mathrm{m}$ with $20 \mathrm{Ncm}$ of torque. Concerning the gold cylinders, the values found were $14.41 \pm 3.84 \mu \mathrm{m}$ with $10 \mathrm{Ncm}$ of torque and $12.26 \pm 3.69 \mu \mathrm{m}$ with $20 \mathrm{Ncm}$ of torque. After the initial readings, the cylinders were submitted to waxing, investment and casting with palladium-silver alloy for the gold cylinders and nickel-chromium alloy for the nickel-chromium cylinders, and then reevaluated. The measurements revealed $20.93 \pm 7.10 \mu \mathrm{m}$ with $10 \mathrm{Ncm}$ and $15.77 \pm 4.72 \mu \mathrm{m}$ with $20 \mathrm{Ncm}$ for the nickelchromium cylinders cast with nickel-chromium, and $11.79 \pm 4.06 \mu \mathrm{m}$ with $10 \mathrm{Ncm}$ and $9.59 \pm 3.25 \mu \mathrm{m}$ with $20 \mathrm{Ncm}$ for the gold cylinder overcast with palladium-silver. The results demonstrated that the gold cylinders with the higher torque exhibited the best fitting before and after overcastting. Statistically significant differences were also observed with employment of the palladium-silver alloy. It was concluded that single-tooth implant-supported prosthesis may be indicated, being that noble and semi noble alloys present the smallest structural variations. 